注のら党ら賞

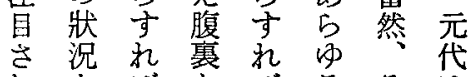
れをばとばるそは 放解不江: 方机中 ば消完南元面は國 なし、全と朝で前に ら、无での佰代壬 な統變異出位のン い: 則な現学 遼

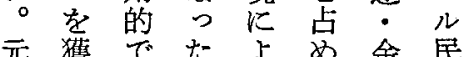
代得市行口布章族 の し 0 政 $\tau$ 雨 歴たたのとも王侵 史のと手字言朝入 がでし法かわ斿し

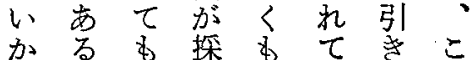

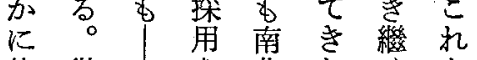

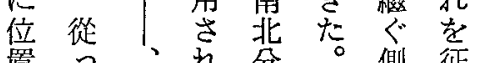
置口、礼分。側征 附てとた斷一面服 元に元

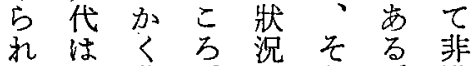
る、蒙がにう。漢 分來古あ終 乙 蒙民 宗全。步た古族 上き苩と符歷全權 远統長江打の尼 の一といっ舞主樹

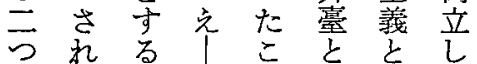
のた元| 研明朝つ江? ? 究清のま重た、い 斍の出り要中モわ 角踏完な國ンゆ を會に全意のゴる 心党よな義歷儿征 か準つ統㤎史人服

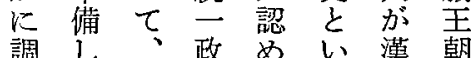
和た中策 55 人 さ之國之设地户時 世心は以上域南代 るら南 5 的人で か 意北觀。觀の あ 隹味對點た點上る。

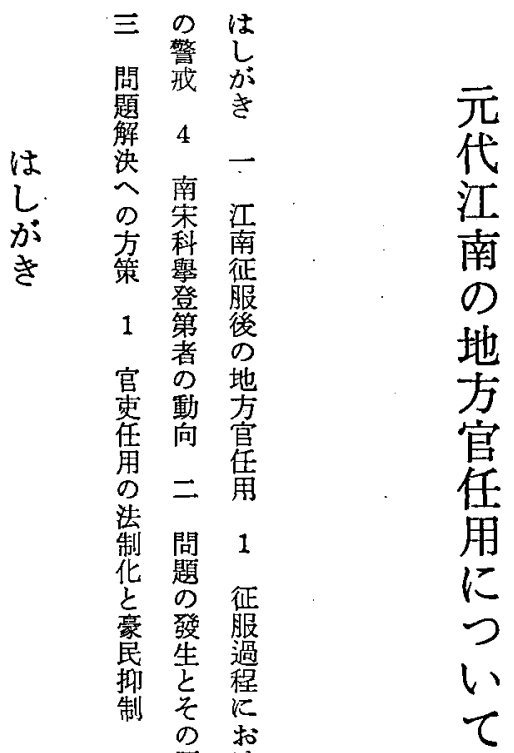

2 原讨

科因 㗊

擧 1 降

再圥著

開官 命

結 題 2

$\begin{array}{lll}\text { に゙ } & 2 & \\ \text { 宋 }\end{array}$

加窃

党家宫

七闃再

南題 再 植

閭 3

題 世新缹

の
問 官
題 
蒙 1

軍 征

が 服

南過

中 程

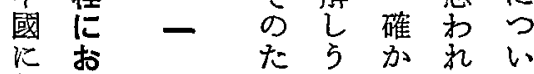

唚汀方汇当て

入古南なない。の

寸投南基占少々研

る降征楚注に机究

之者服的、るでは

中命後作宋征は從

國

な

か

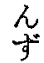

南

策

政

倪

こ

新

L

支

夌

者

K

對

ᄂ

$\frac{\xi}{3}$
地军 元王朝明京

方究明 5 方

官てのし 漢豐

任 $心$ 歷 $心$ 族副

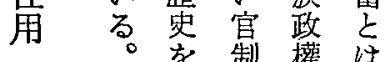

一製篗

貫 の 對 克

乙措比交

た置 L

れ認、

のめ元 蒙

比南

位弾配

置守にの

亏例 無

けが外原

る 的 則

占㤬性

方热代恣

可豪と意

能㞎さ性

飞間杂肪

な題る强

るをに調

の政 おさ

で治わ就

は串っる

な、てき

W官 ᄂ

か制焉 以

と史亏が
流 哂

中 5 代古
でつ近をす注を題

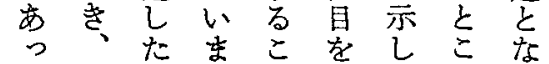
㻌古姿可集たる。

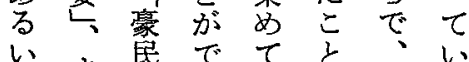
はま民でて衣安る

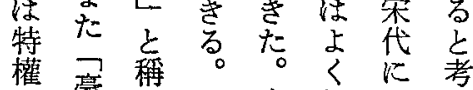
蒙莄宋知 有毕て代: 5 新 寸官和史明虹興视 官官料两集学学 官結た侈に代い農 とび。党摤。地

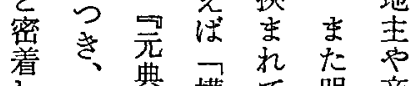
乙县意權て盟商 關傧意豪元代全 系拿は豪代瑯蒠 保记家方紳的

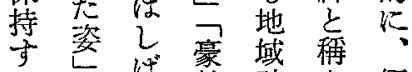

るコ勢 社さ經 こと官會就濟 と解㭡豪儿る的

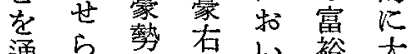
通员势在い裕大 しる富勢店い

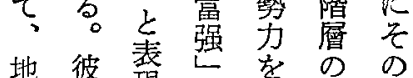
域等現势有各力

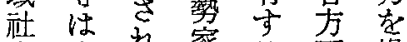
會中机家吉面曙 先先富に大 絕政が等裕方さ 大府こ語な施 影地和势地总政 響方は官心治 力官二气商影的 を浯蒙て人響に

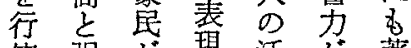
使强方現活落蕃 乙 固 政さ動 從 L 治机を來い た結接者確方盛 


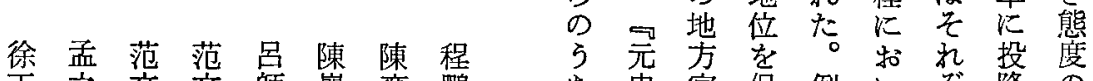

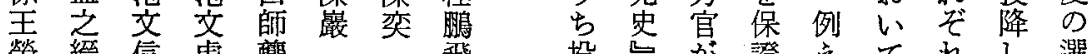

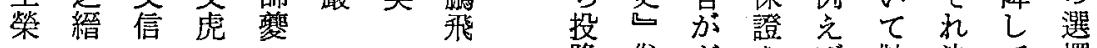

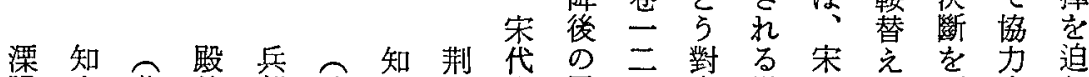

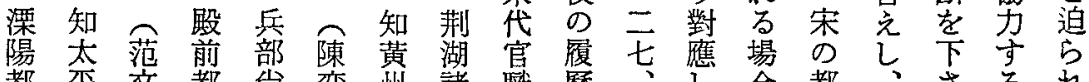

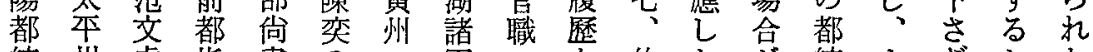
統州虎指書の軍落伯たが統まざかた 從使子都知顔吕多や統鞍を市最

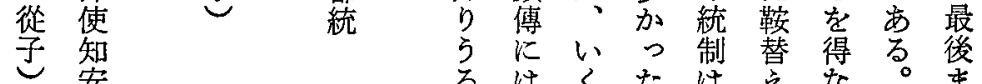
寞

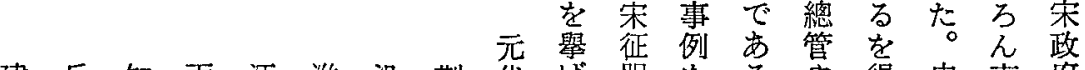
建兵知兩江淮沿荆帒げ服をる。得史事符 康部安浙州東江湖官れ過充。招な籍態を 路佾慶大守宣大宣職ば程げい討かには支 總書府都】撫都热次にてま使っはた持 管事督以使督使の就考敢にた元やし

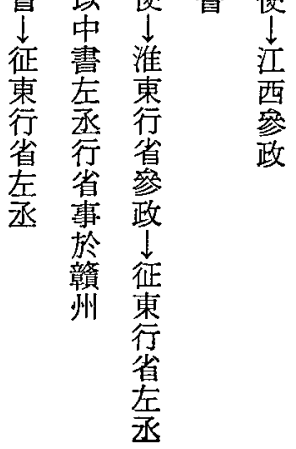

上小党光任质軍すて

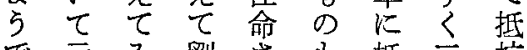
で元み劉さ文抵云抗 要策杂多抗 分范 る 降交民で戰るる

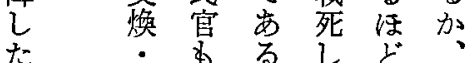
た數蒲抵るた鬲々 多育抗 宋的純 水 $<\quad$ L の とた軍が進 す 人 名口の审WL \& をた投名表たに 見名降々面わ南 出高でのに策 导 Wな官出で荠 こ人忷少は見 方名礼見がな限

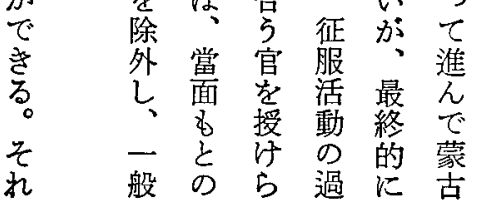




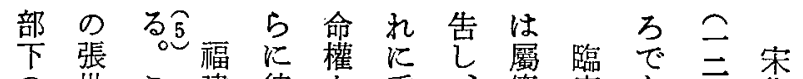

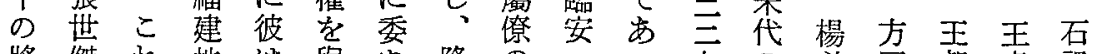

將傑礼地

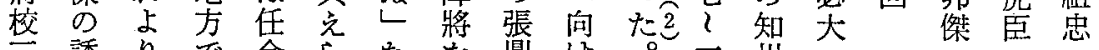

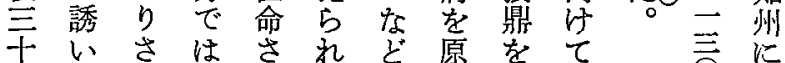

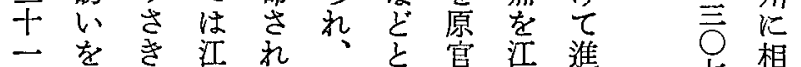

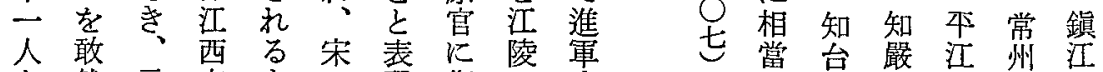

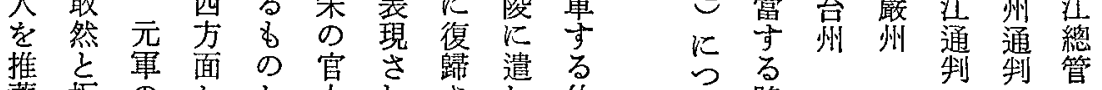

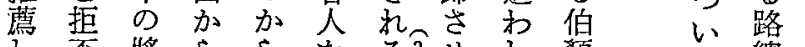

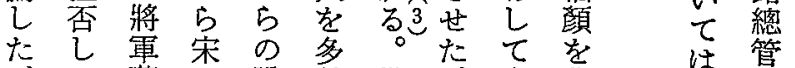

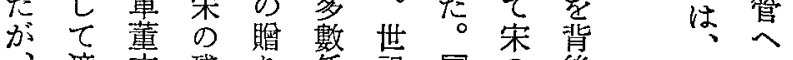

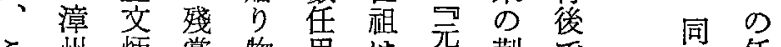

こ州抦黨物用は元荆で

の安肪ををし廉患湖支

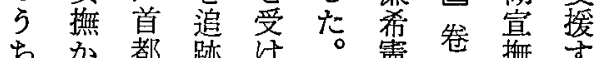

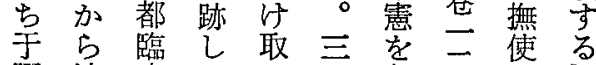

躍漳安て唯急云分阿

な州にきのと遽八朱里

る路菂た究拒点召阿碩海

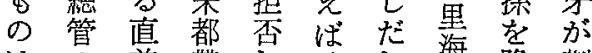

はの前帶し路し每降荆

後地飞永て品て牙服南

飞位、地、總荆傳さ地

總宋元人管南にせ方

管得の向官地はるを

にた。福魏を相方々を市

任建炅大賞の文定

命ま路祜い导統降朱し

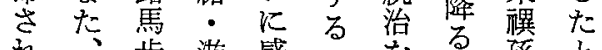

记步游感第委所捼高

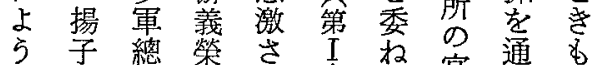

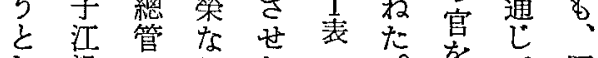

し沿のるた コ。官て同

七 沈为元廉官湖樣

果黄蕯に

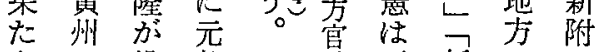

さで投朝職鬲新のの

な投降の品豆附各者

か降し官表以品州老

吃た老毿者に角

た合た。與參の离歸い

同任

帒 命

周嘍㕖建平平江

密多州德江 江 隍

二記 撫 總 總 總汇

三錄 使 管 管 管 安

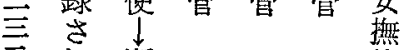

劣椞

厹心宣鉏

分㾮江

が。副路

舌建使總

鋒 德 烝

之旡或路

の 5 京

變 宋 知

節 代

ぶ

り 嚴

老州

非

蜼 の

乙 總

p $\varepsilon$

まな

なっ

丳彼兌照官点附た

は宋いさ任こ勸彼

いた

方 


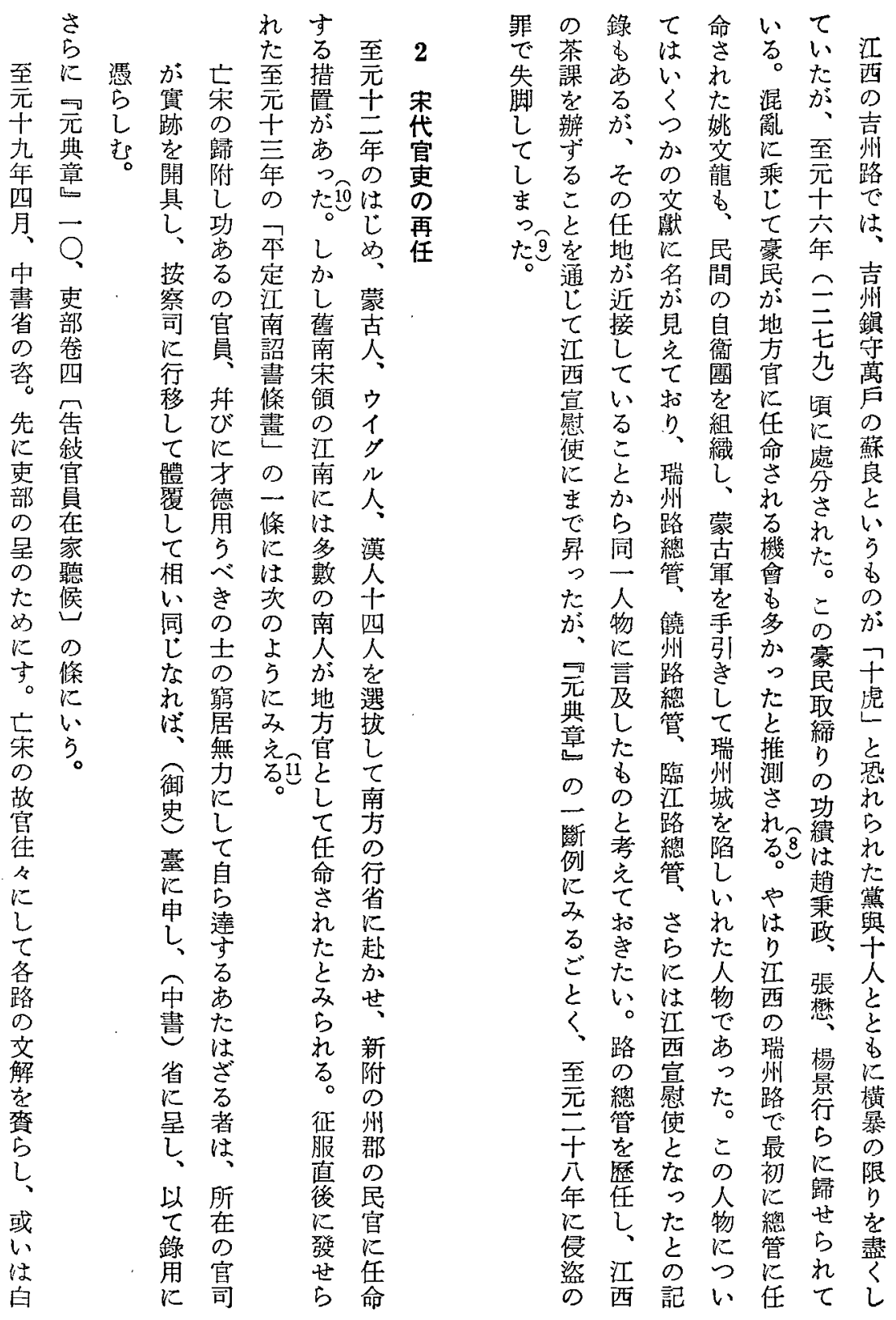


死發質る 留通熋

だの取で夢て來ず甲世南南の法司司あ狀

の任ら㐫炎出は。戌坥の方辭官ににるを

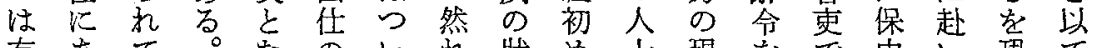

有あて。なのい犯牀め士現をで我い恐て

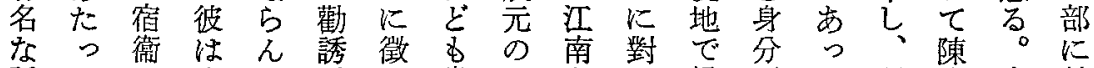
話たに宋でが召肯王をし歸證た照告今赴 で。入のそ行に合龍得て附明も勘せ後き あ 謝り知 $う$ わ應て 澤る

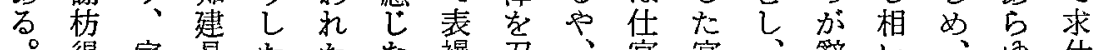

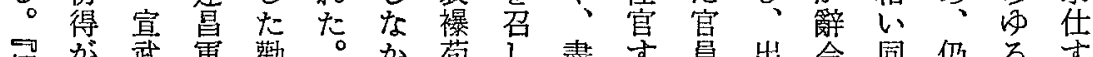

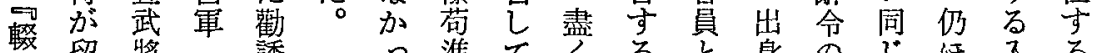

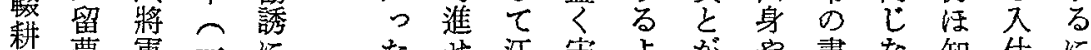

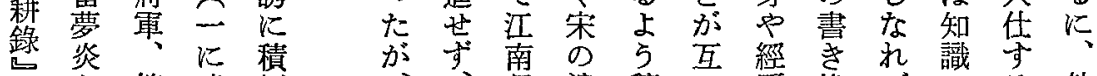

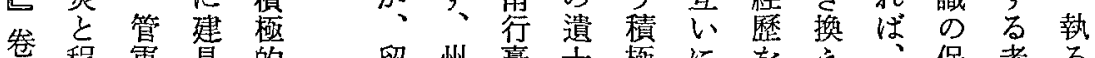
忩程軍昌的留州臺士極にをえ保者る

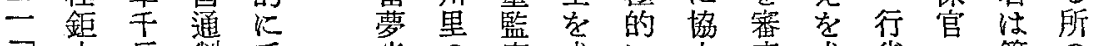
不夫步制手炎少求に力香求省三籍

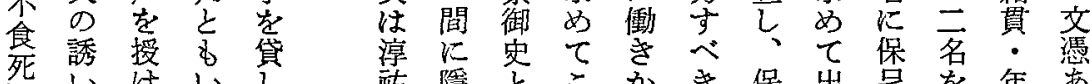

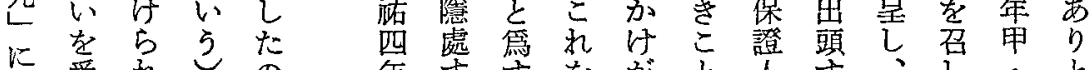

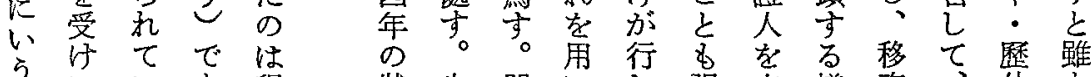

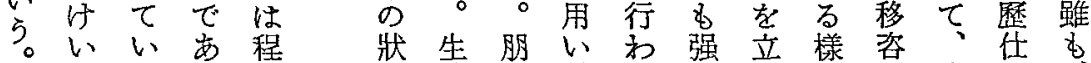
就た鈛 吉倠た美

最や秀名 後方の注 厄て 程 文

は䓚鼎海 大都卿 武

源我宗

連 い卿 の

行 信諱

岂賴孞売避

$\tau$ 得軍访

\& $\tau$ r $\tau$

属江降字

泀南服索

盛比紫

断食漈精

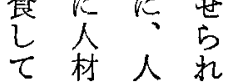
元徒來、狆調竞森し官

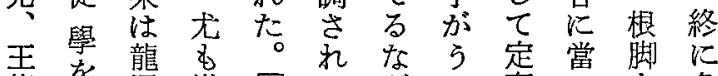

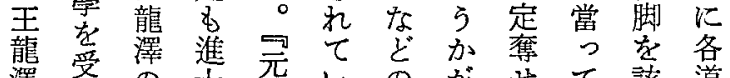

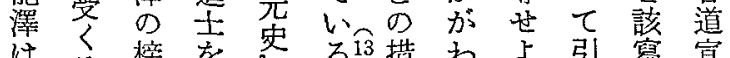

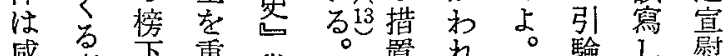
感者市重卷。置杂。驗し、慰

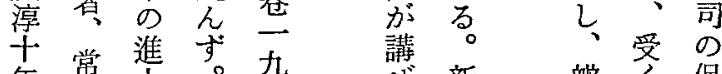

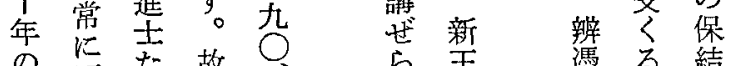
の百た故 $Q 、$ 禁憑る結 狀泉 引相熊机朝所の

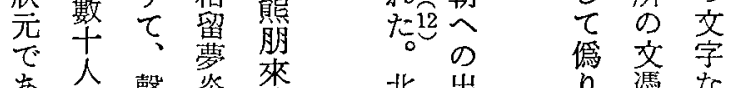
あな韾炎萊北出方憑な

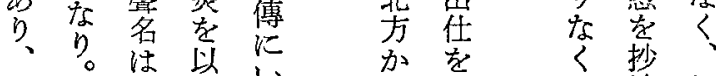

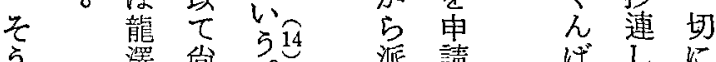

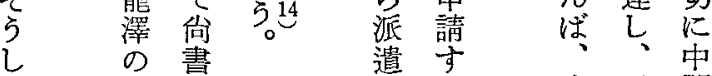
た 市書 遣主 本元間 名视場道籍に

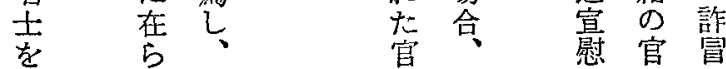




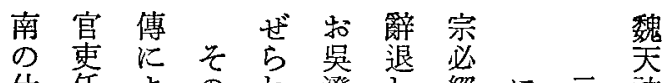

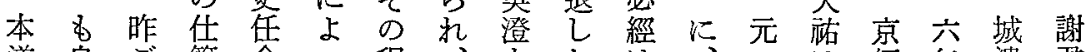
道良ご籍 命つ程、もたは、のは師年潰君

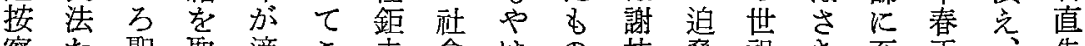

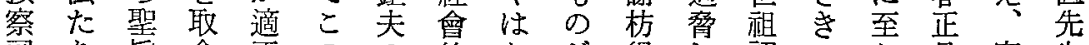

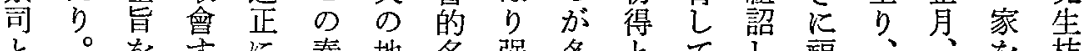

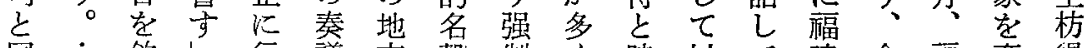

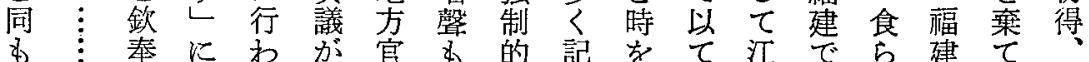
它乙性至任は䟿同去南投性行て:

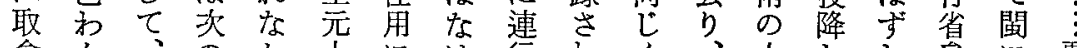

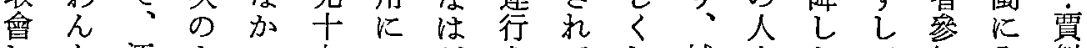
ᄂ

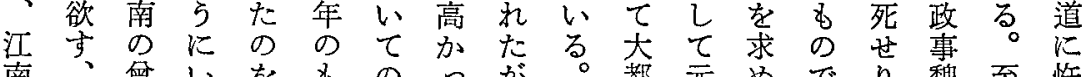
南、曾いをものつが。都元めでり槐至怍

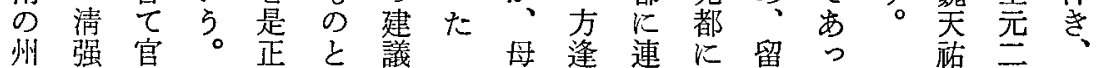

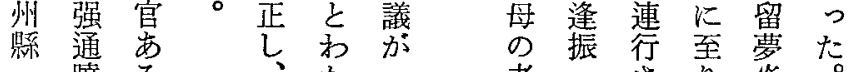

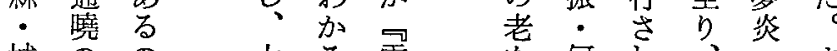

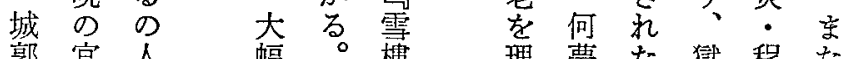
郭官人幅。樓理夢た獄程た

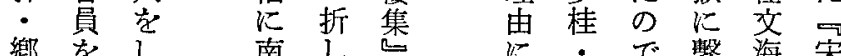

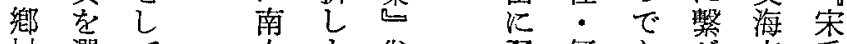
村選 $\tau$ 人字 鄰び繁探离 甲南を筩 グに が 北 䨘

保苦占人光

明論しち莘る 詣导る省相古 ななにる合治 ５く赴意馬五 し、圖の事 め省て 肪失它 省換稳 脚で も授市市

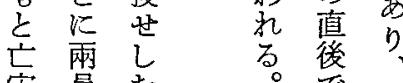

宋員的 に老る 在差美 许 七晏前 弯去保 る せ 此 元時 人最江に本

翌何京艾季 年逢万多忠 二原 $5 こ$ 謝義

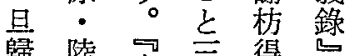
歸陸穼焉墕先

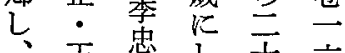

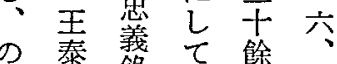
ち來錄? 宗 に。乃を必 元吳 5 鹿經 潮仲宗還字 仕必染子は 克棌經 江興よ方学 そな゙ 㫕 春、象 議阿焱

の 合 -

第 馬 七

一 時 三 


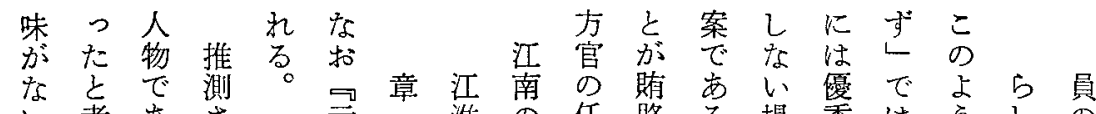
小考あ云元淮の任賂る場秀は引しの

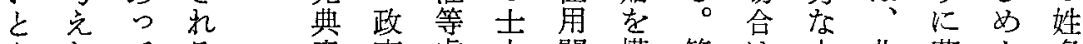

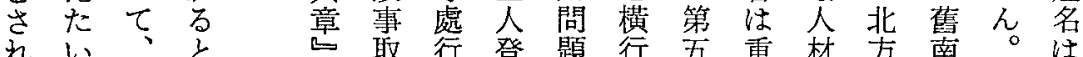

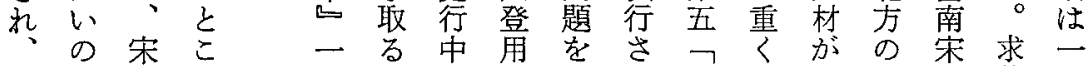

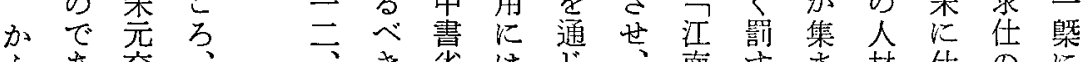
之あ交、省はじ、南吉材仕のに っる替荣吏者のつて㩁のるりに官人籍 て 明單際委等ら元貢彼を更う心いた市置 代にし忠六ば義にな酷ににをて人るる の 保 $\tau$ 鐵 記身 同 錄 錄 の

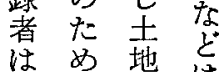

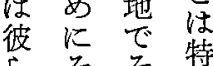
它交等

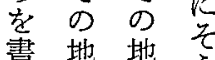
蟏地地 加范范 等保满 榤等忽 整毕

当凡算

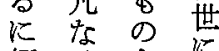
傾地战

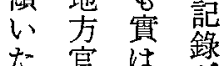
た官は趋 学想殘 で炎賞等 な吉存中 皂在す 坊号㔔 哥糜之。 加和の 。記和

錄記節

のさ錄を 意扎曲 喿当殘将

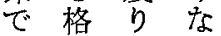
别飞京 康等く 嚕意加た

の、十⿱亠乂

元八心にく錢提少小遇本 歲れ年 實さ案北: りは人

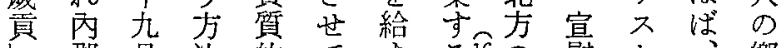

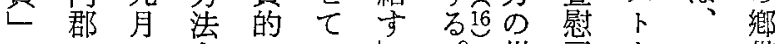
ののの\& 目體篈め中るで第縣. 作閱产

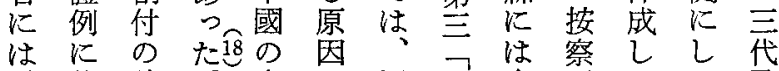
は依該た南恩江考南察て元贷 科方四北々南功人な、学び

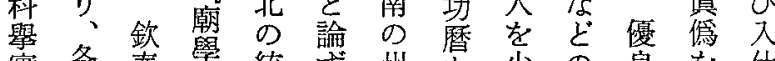

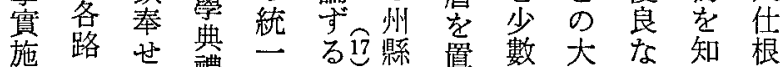

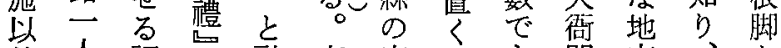
前人詔崖融南官らを門方、を に畫兊合人更參に官極明

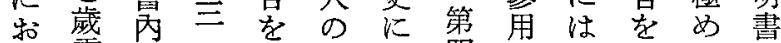
讨貢の行回登至四し、皇確て便、

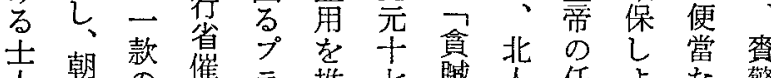
人朝 $の$ 崔

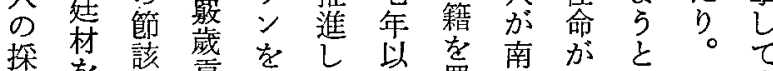

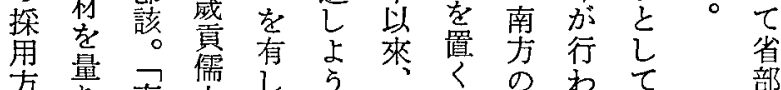

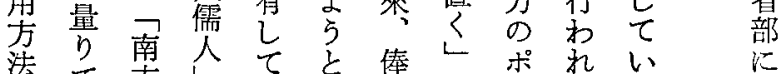

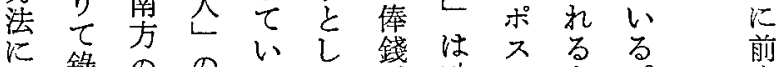

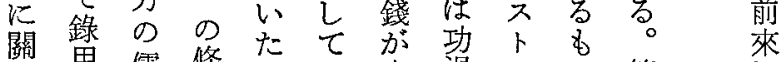

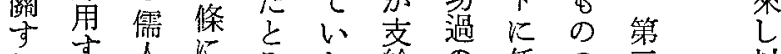

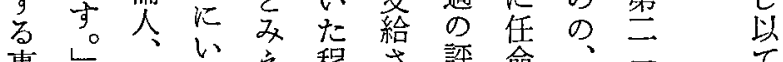

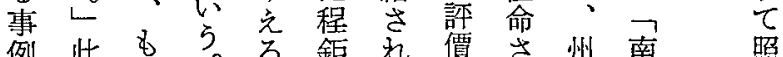

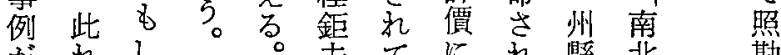

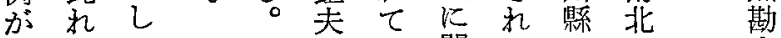
多を德比關てのの主

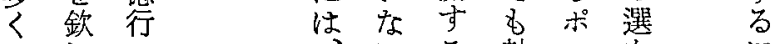

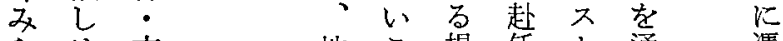

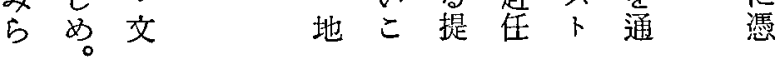


に號亡

のがし の む れわ

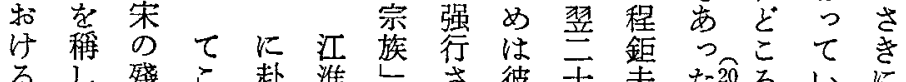

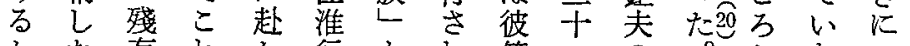
かた存れか行とれ等一の市ない

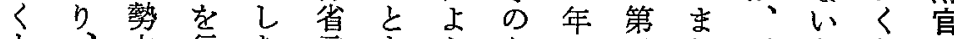

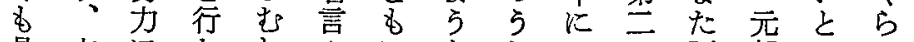

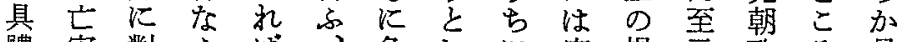

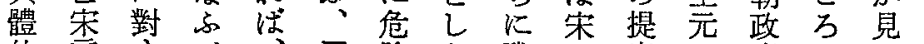

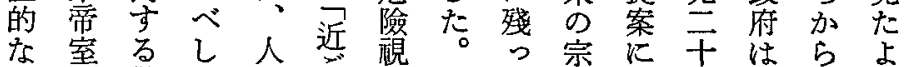

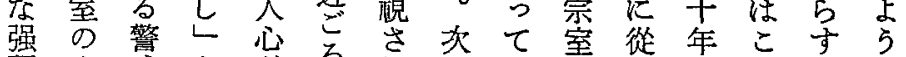

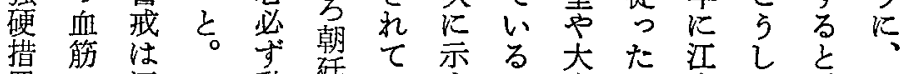
置の江こ勳廷心守官南た舊 は生南れ播香る可を宋をのの者格南 大を平飞を絜。元の㐫と地達别宋

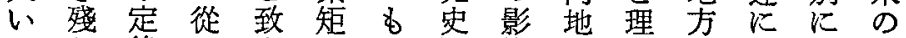

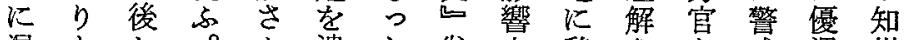

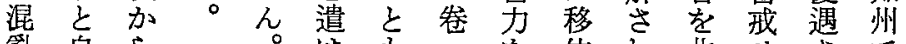

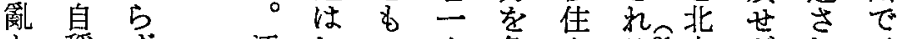

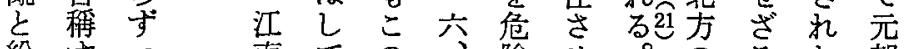

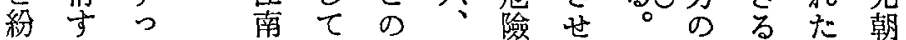

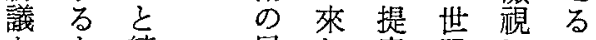
を文續尼た案租しこ क $\omega$ た が 5 現 ᄂ 独た た た 㕦宾南

交 $心$ 頻 公 集吕公

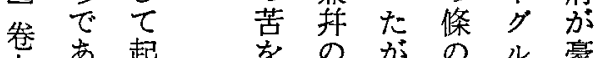
恶起

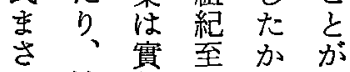
沙行完占計

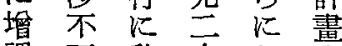
㵊丁移干古焉

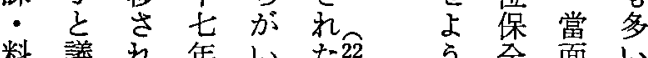
內存方补 郡党诂仕 飞度で

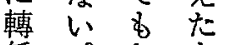
往。度和 巳一地 $<$ क せ 位、的 議染年いた泪な方全面い。 - ᄂ 乙月元的地し 括めな癸。朝た明位か 馬、か未ウ政的た保し の兼っのイ府はる圣彼 苦科た條グ加、金飞ら

新䖍步完 患手。記人民

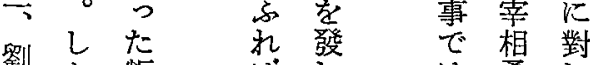
劉加软 中 ᄂ 筒 墓拿虫

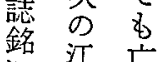

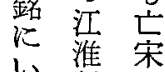
岁集采

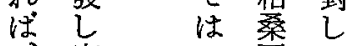
宋哥 $\tau$ 宜手筆䇾

ᄂ宗我鹳

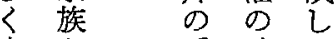

它方時炕

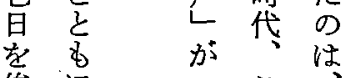

。省

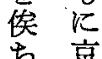
罙扂

官をっ代 へ取た の 引 \& 特 警上の溥 戒济かる と过 事 同 5 乙 績 時と就 にしな市 た

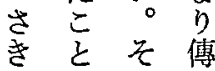
臨 江 新志 官 卷 の 警官 戒帥 に

出

鐩

c

少

數 の

路

總

管

名 列 舉 き わ め 示 㖫 


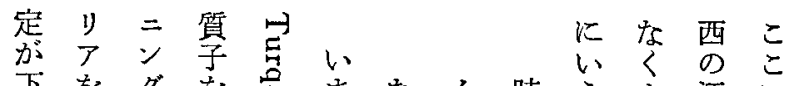

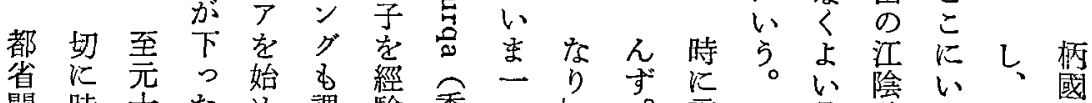
聞時十ため課驗秀つし。帝具路 5 未 奏

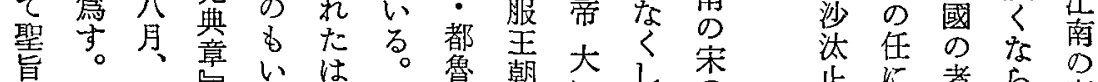

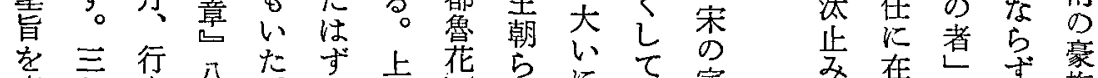

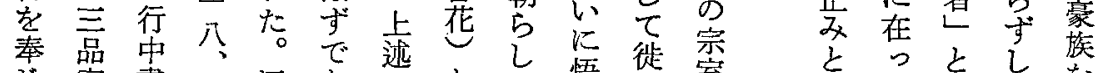

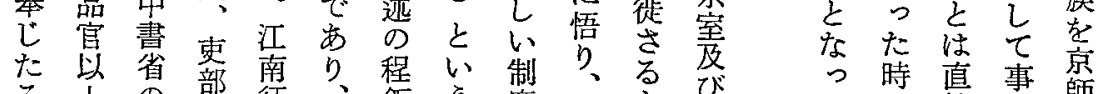

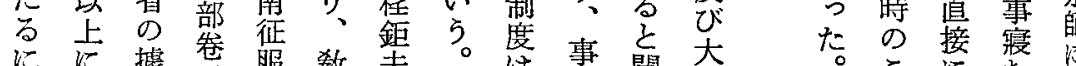

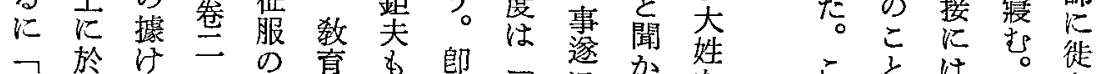

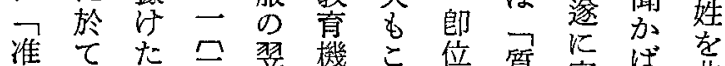

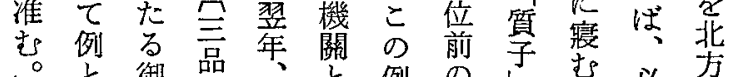

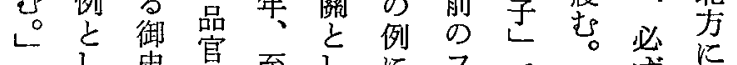

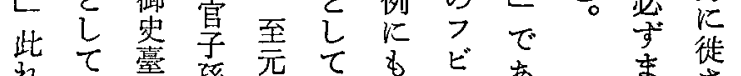

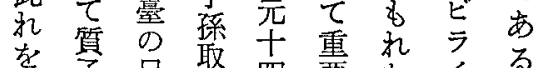

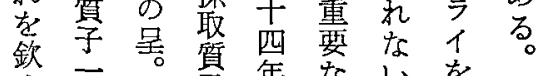
め。名伏出年意心をしこ

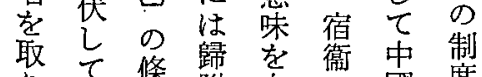

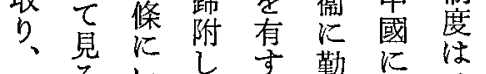

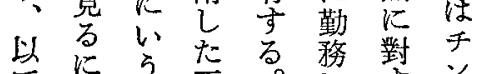

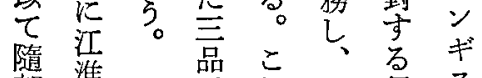

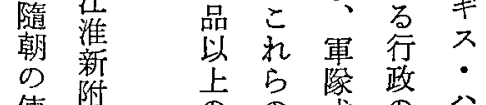
使附 穴 9 武 9 官

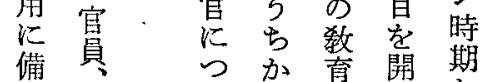

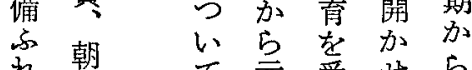
れ䅍て元受せら

ば優、朝注たあ

長遷質行各有り

便卞手政方名蒙

たる人官蒙廉苦

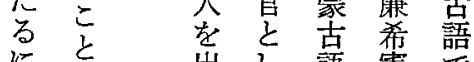

に甚出し語䨓 呚

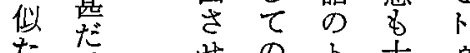

た重出の古の

员重令 $\neq$ 決帒少

亲徒

せ

。 李

萬 間

$-V$

奸 乘

人艺

离

嚳

慧宋

它案

起 歸

ば 命

國其

利会

尔田

$\begin{array}{ll}\text { ら } & \text { 里 } \\ \text { る゙ } & \text { 安 }\end{array}$
こ

措市置雚

對彼者官

しは古屋

實由桑 郡

行壳哥学

阻指

占 $\tau$ ᄂ

乙 命、起

た令白遣

のの 絜

は實 矩

葉施 や

莠を乷

王市

延

さば彼

。兄腹

兄 朊

史てで

结

卷た。

$\vec{亡}$ こ 劉

恶引、舎

本京

傳占浙 (a) (n) (n) 
元代江南の地方官任用について

年州元士

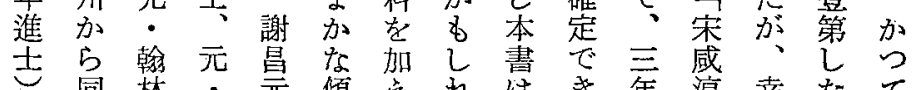

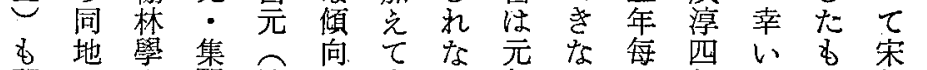

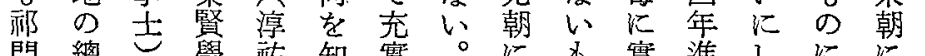

門 總學政知實。江實進しにに

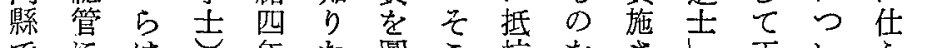

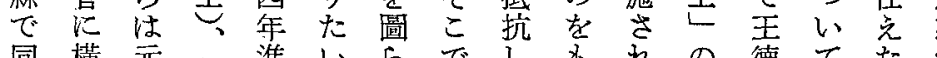

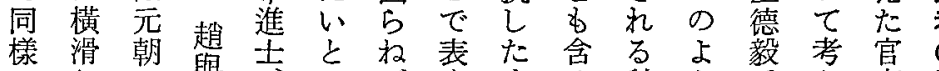

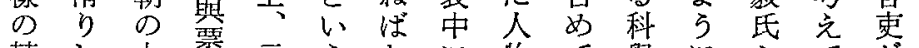

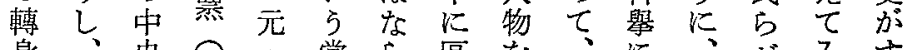

身、央成・賞ら區を、に、が るす

を方政顑禮面な別顯第合人作たべ

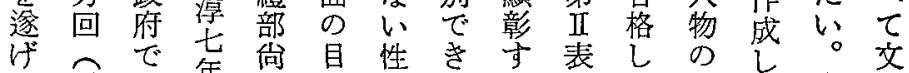

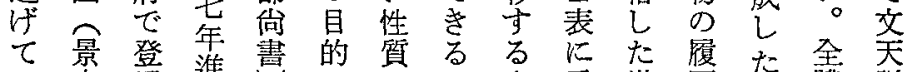

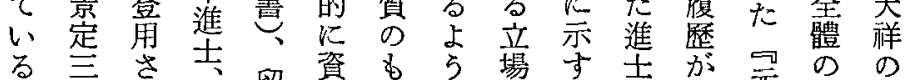

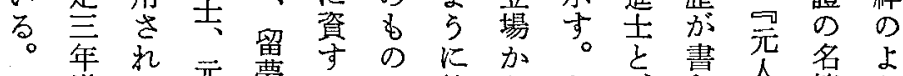

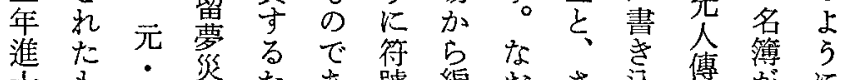

士も翰災た市號編括さ这傳簿 5

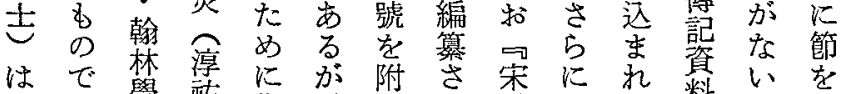

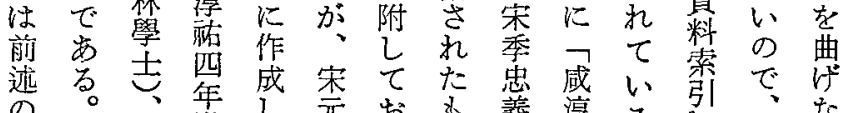

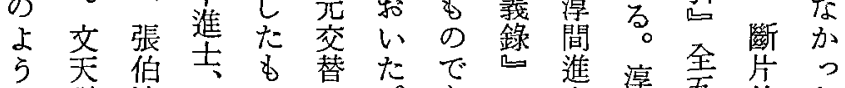

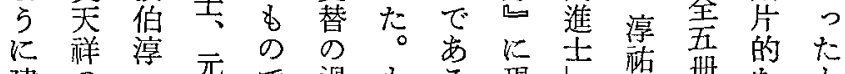

に祥㳯元

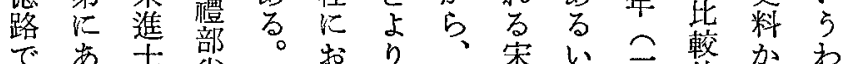

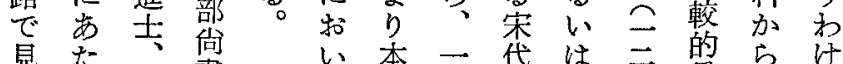

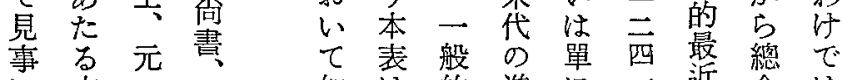

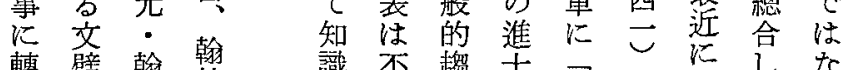

轉璧翰翰識不遛士

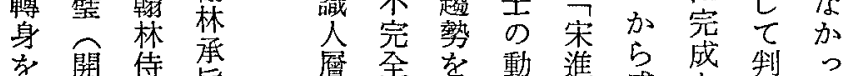

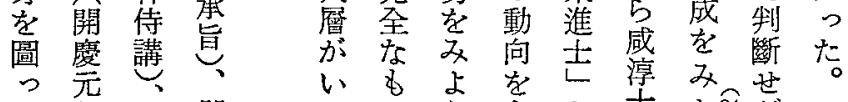

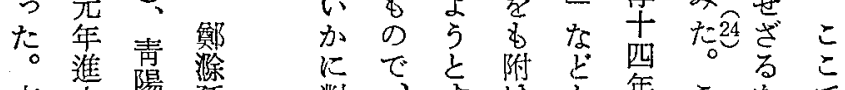

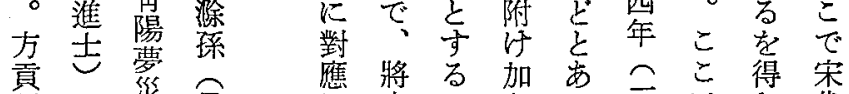

貢倠將る加あここ得宋

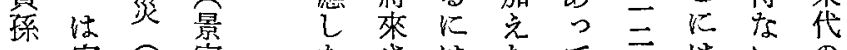

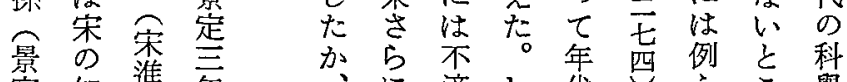

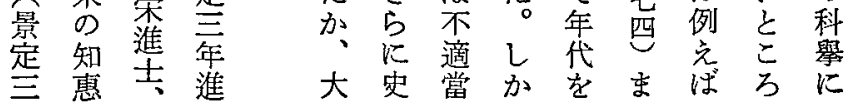

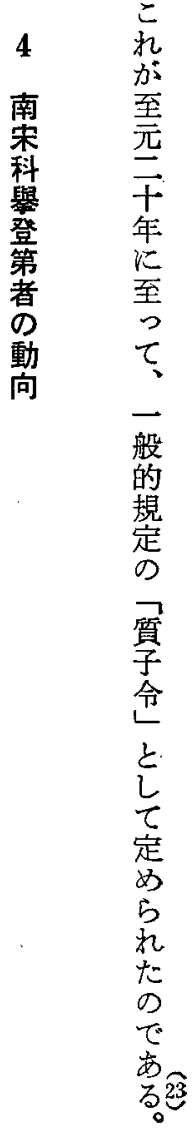




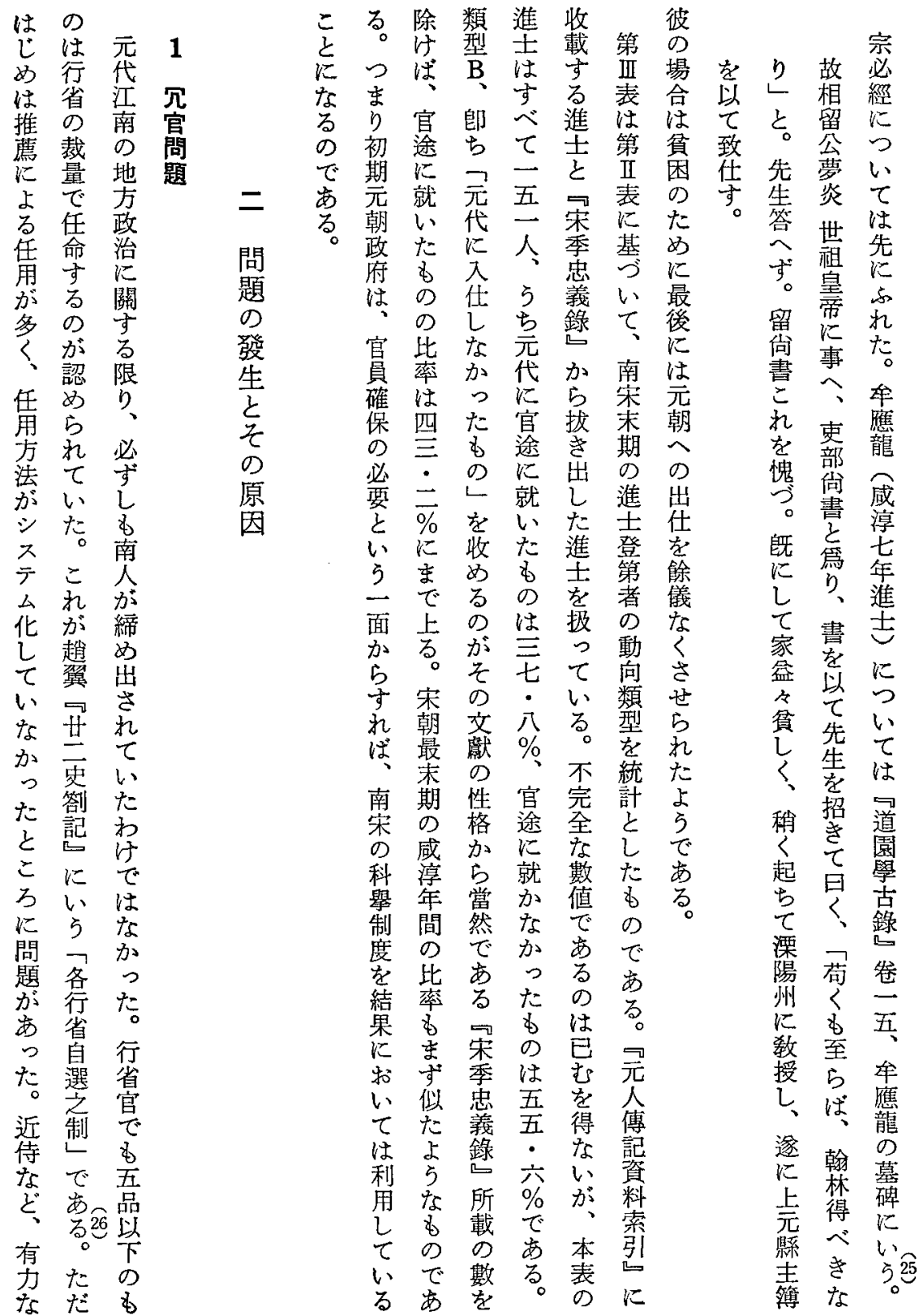




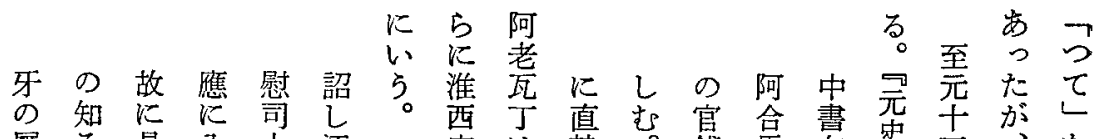
屬当是入十江 吏所 のに命守道 の 張乙あべは兄 鼎てり。額官 今皆: 者設を 亦な 症垒部數。 知嘗顧付除南 政 空 事言て て た 恃右錄外 。、汇等涂 詔聂謂しはた

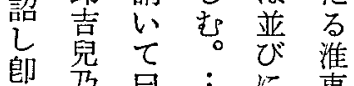
郎学早熦東

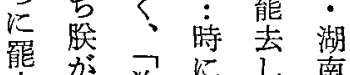
去篇汝淮、南 莩感姚西仍隆

しに樞宣注興 むこ等 㫘 各 • 遂热馀節官福

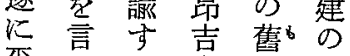
平方 兒と四

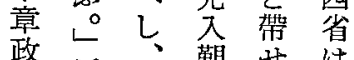

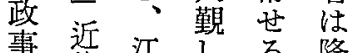

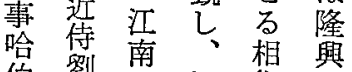
伯䭛南江絎鼠

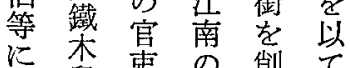

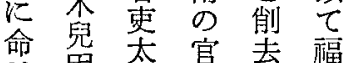

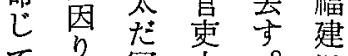

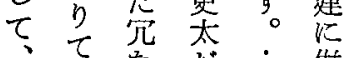
中言等管椞

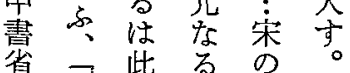
阿设客故其

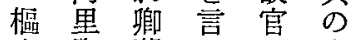
密海䧳客の

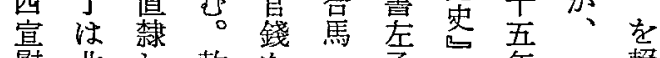

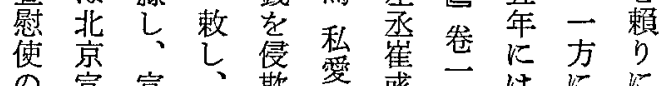

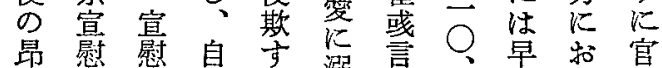

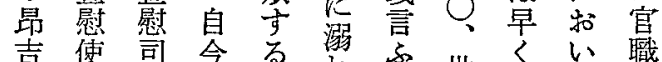

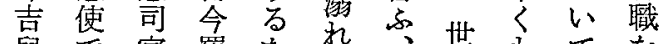

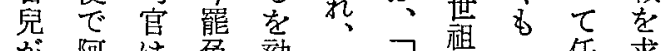

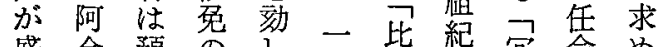

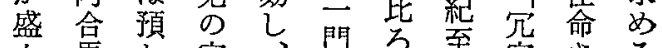

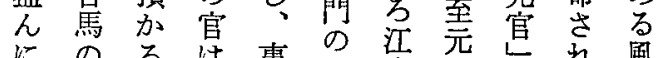

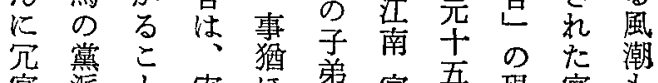

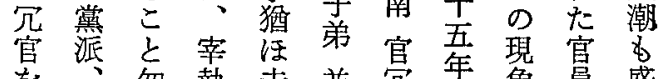

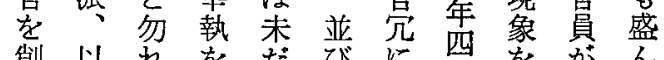

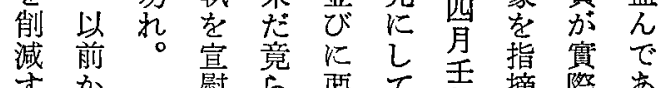

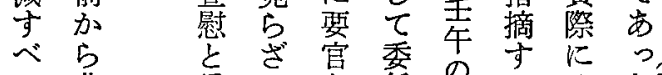

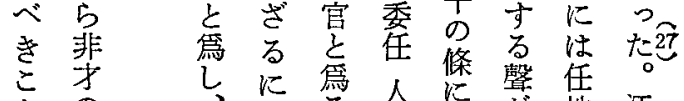

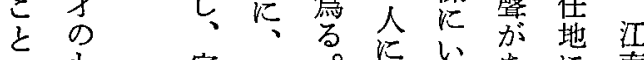

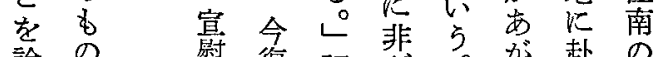
論の惩復詔悲。加赴の

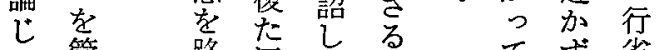

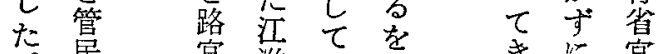
。官淮恶品き官

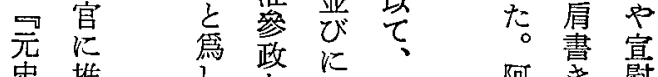

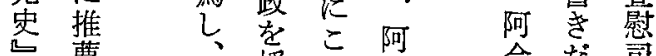

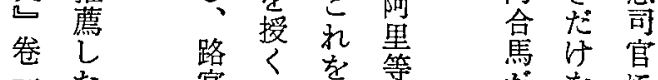

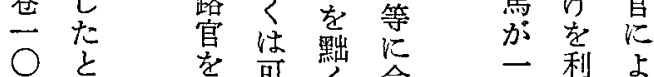

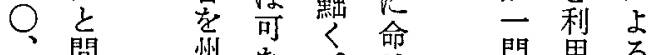

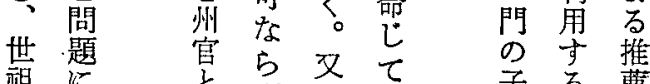

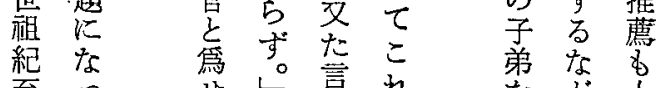

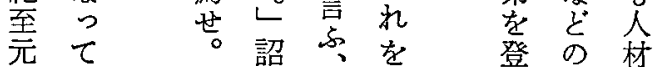

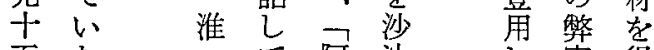

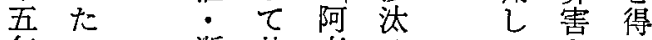
年の浙其老世展多 六での无しこ㩆上

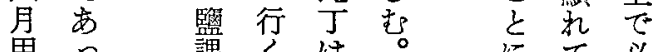

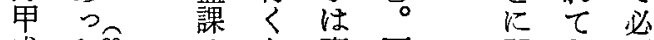

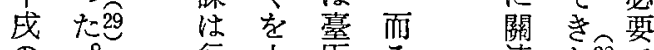

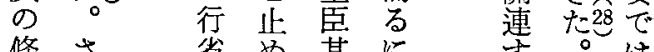
條さ省要其比势。注 


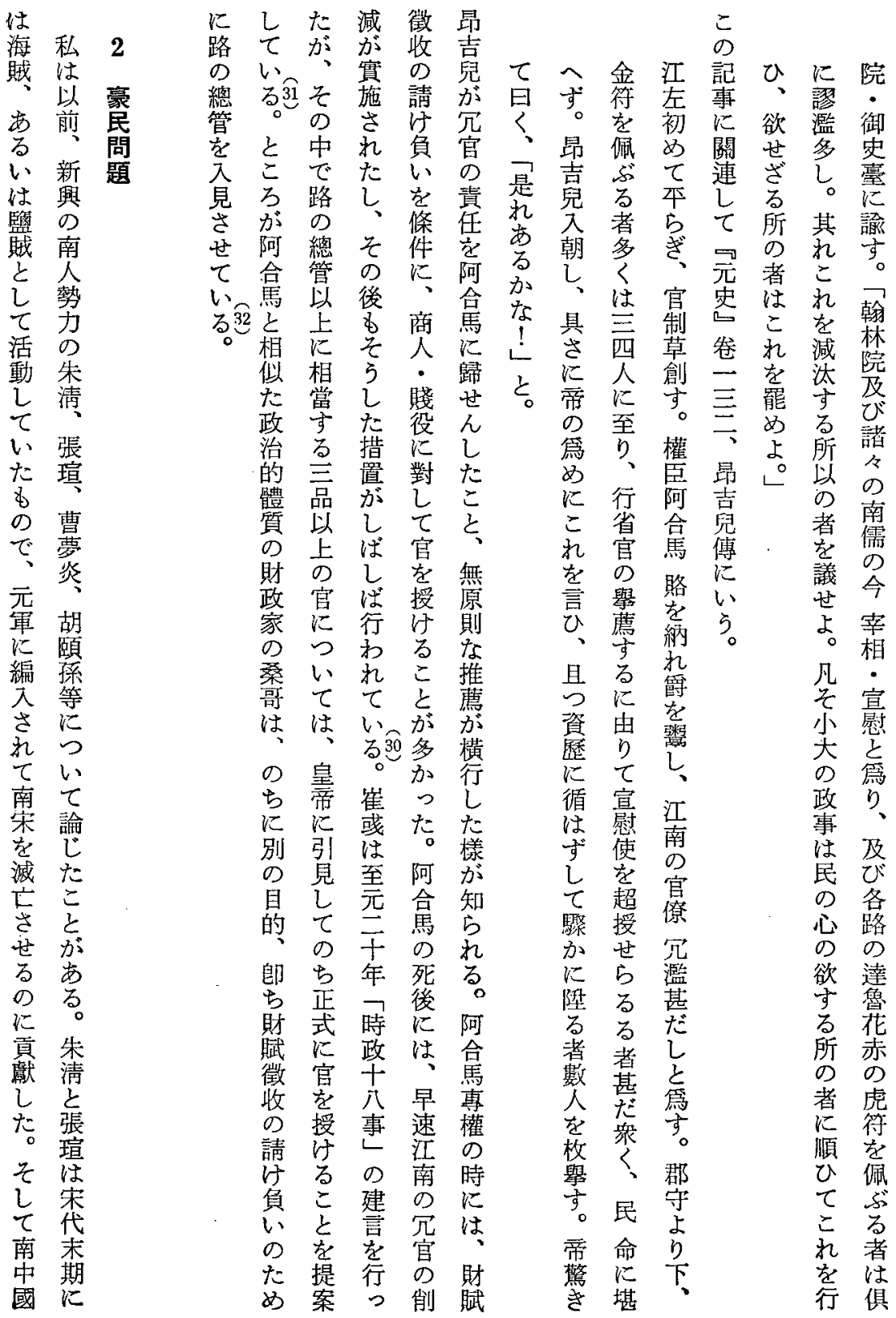


がす井新役混省征

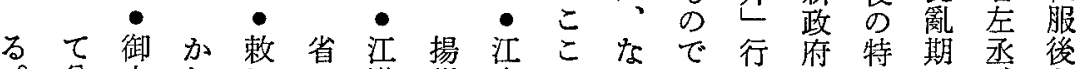

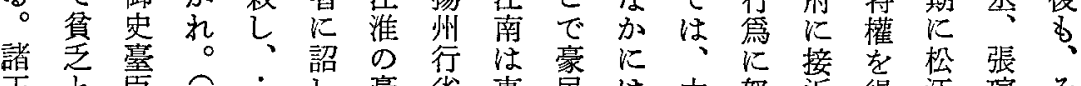

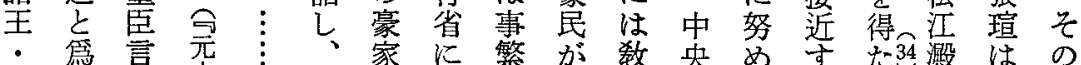

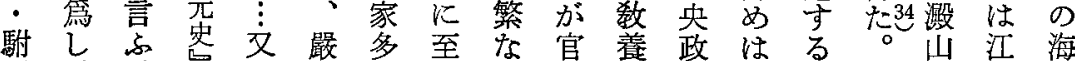

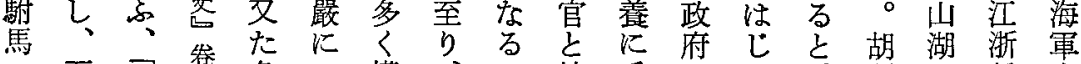

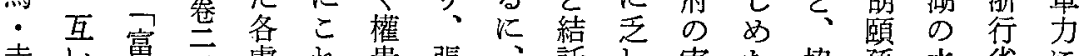
寺 - 恩旨武省禁行智省るっにこしや田丞口

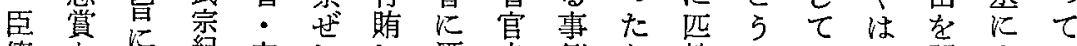
僚を叠室しし潭末例り敵しいいう開ま日

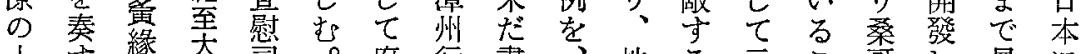

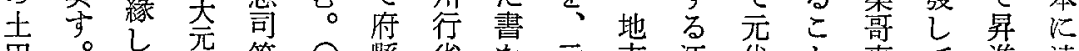

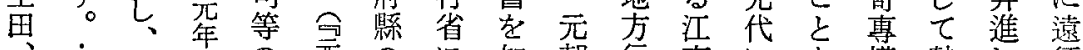

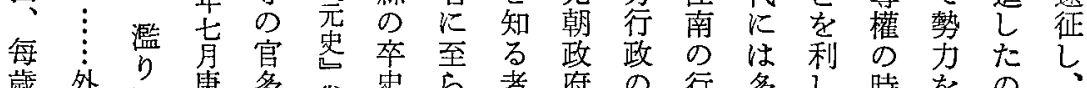

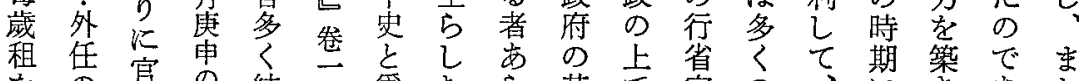

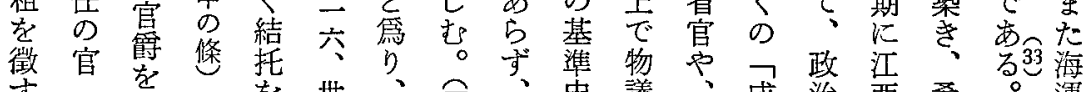

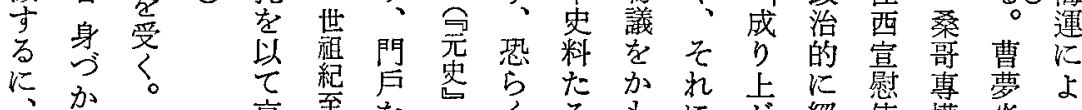

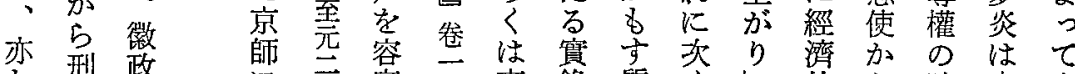

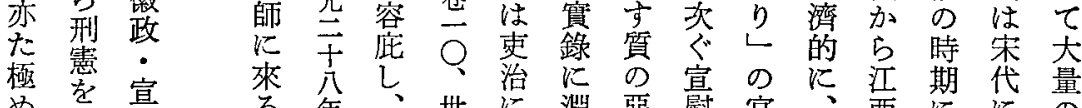
め犯微手年、世に淵惡慰官、西ににの

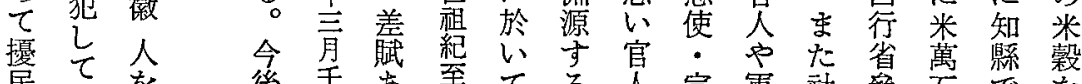

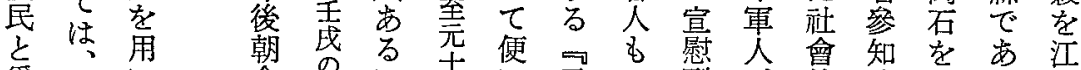
稂軴W 命

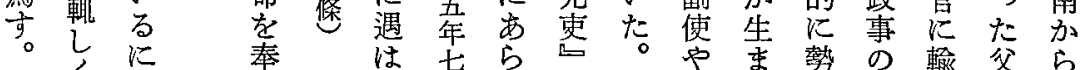

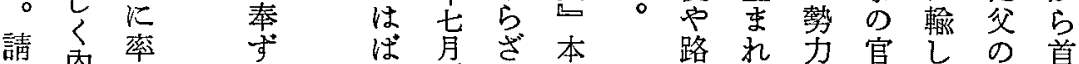
請內率省贫さ本路れ力官しの首

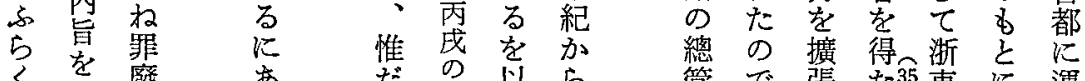

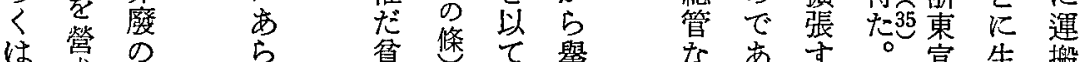

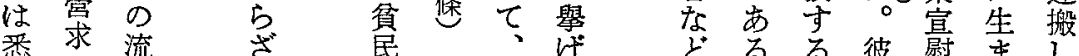

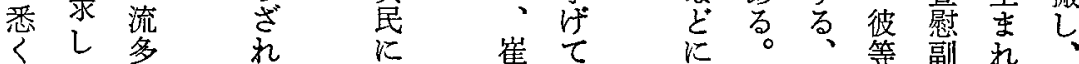

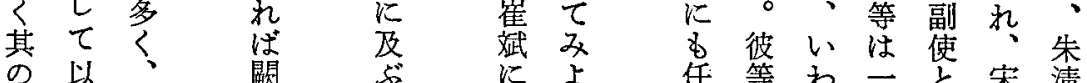

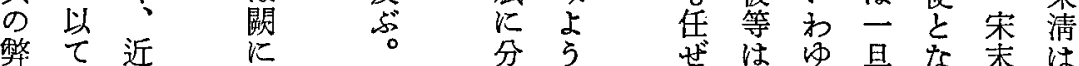

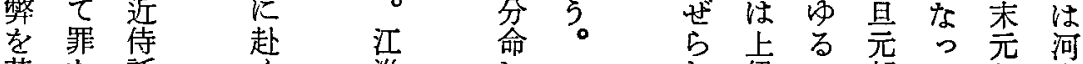

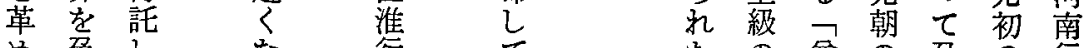

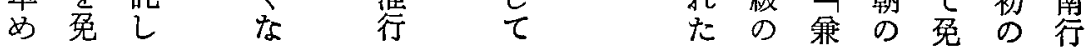


府 $\begin{gathered}\text { 實 } \\ \text { 亡 雄 }\end{gathered}$

武至從西

敖力十院

㹍 行四。官

勢 使 年

力湖

ひ北

錪少の

壓学常

乙

さ愼 で

索重富

机對 要

ば應十

事 心 餘

足た家

万交

るで德

わ出

讨大寺

で事の

は僧

な至と

少

$\Rightarrow$ क क

t妿保

仮 た愻

简

智衣起

力 5

$z=$ 年

古訢

手和畫

离离

結 口市

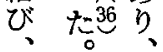

乙 2 時

初的

荆

政 75 湖

府加北

の薄

側富

比元 慰

取朝便

政合
にし問章る護元

いさた題范たを代

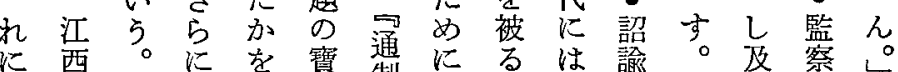

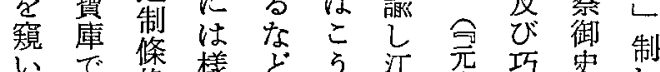
汇心で條樣どう江元巧史制

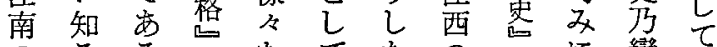

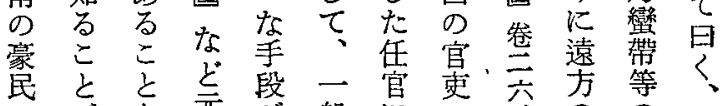

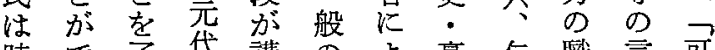
時で了代講の航豪㑘言可 にき解の法人っ主宗官をな 牧るし法ら民ては紀を用り 亂。弓令和に特茶延受、し

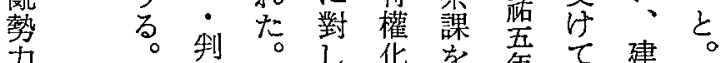

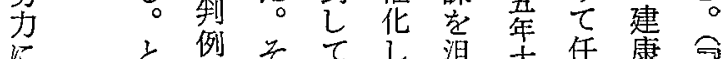

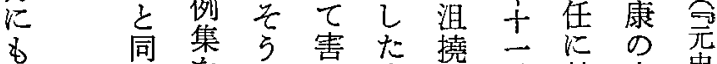

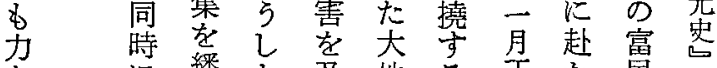

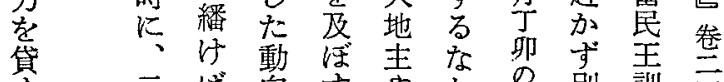

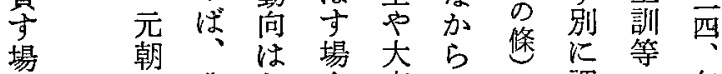
合 $の$ 我勿合商し調の在

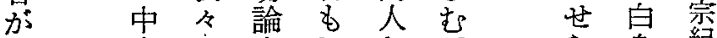
あ央㤬第市身紀

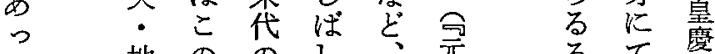

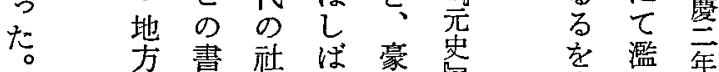

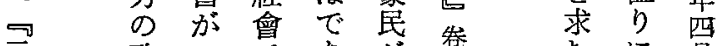

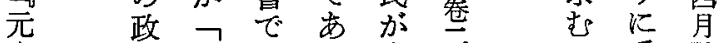
串府官次口自交学竟

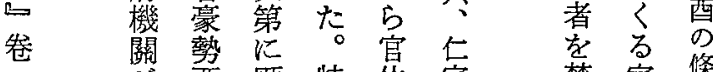

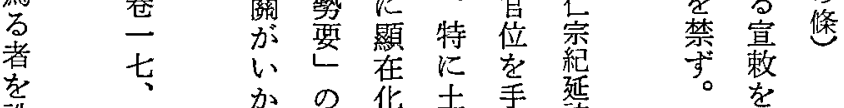
世誅 世横地に䄈

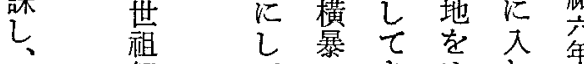
てのきめ就等 こ事たぐた 索

の例名方少首仍

問をの繫、卵せほ

題今で爭或の ざ籍

に出やい修る貫 對傳名納は者を

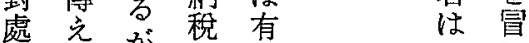

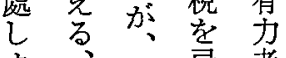
ょ、橤者 ¿ を宿 罪 衞 


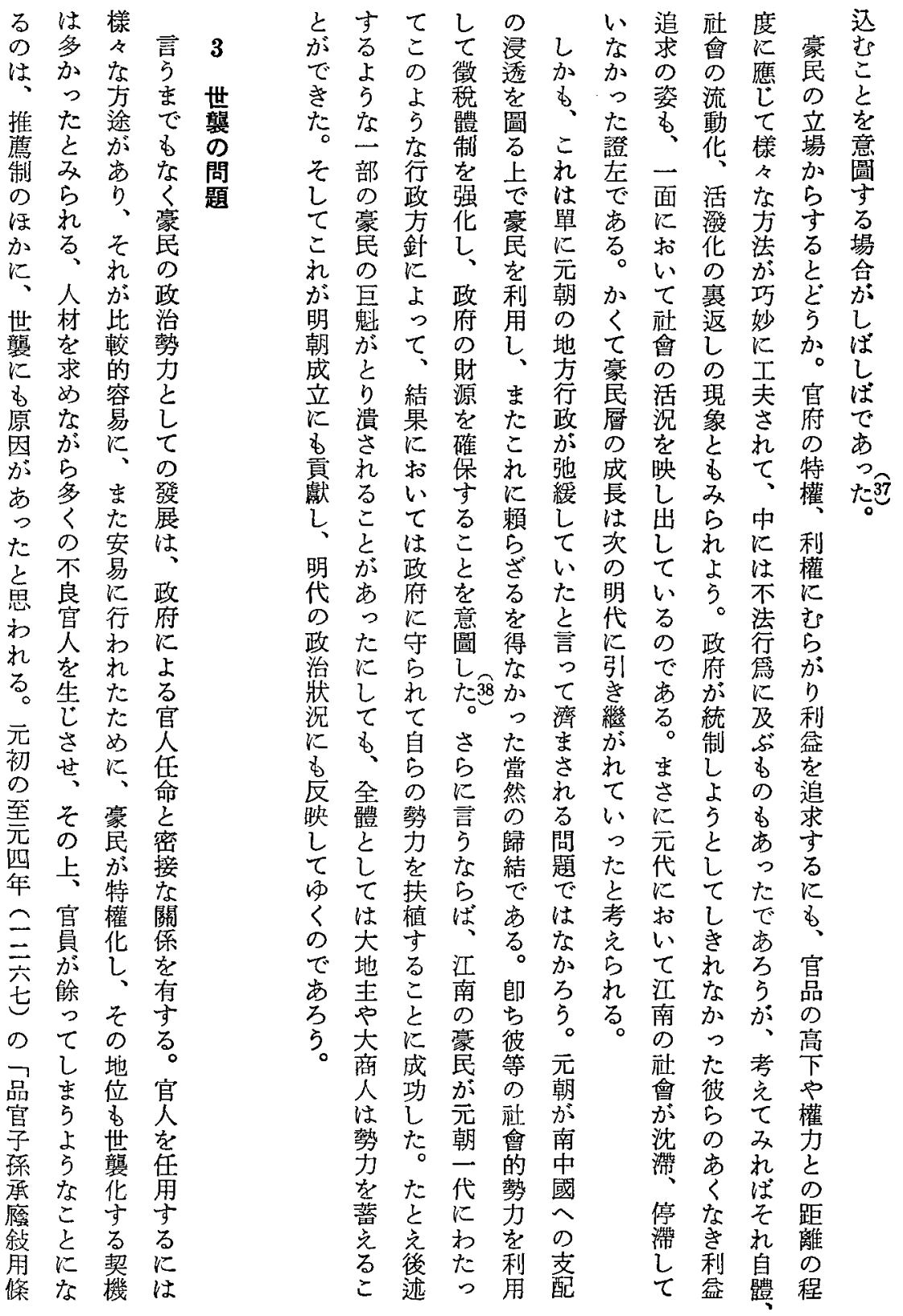


学 て 江世に至

はあ歸換至宋制藏䈍元從正從正從正に 宋る附授元ので頻圖し年九元公七七焉

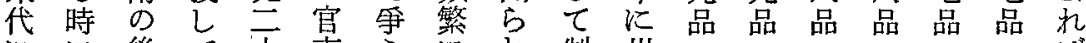
飞に後て干更 5 飞水州 官別全い四の璵る定縣 更にくな年家う党こさ官 で議 換い、のな 從 正從 正 正 廕

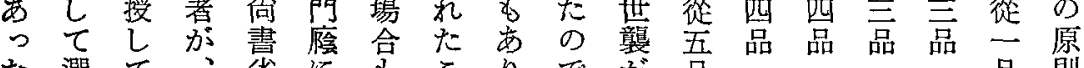

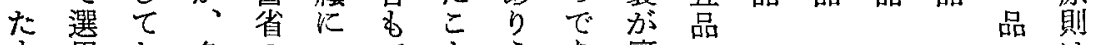
も角お多のつでとう廢 の

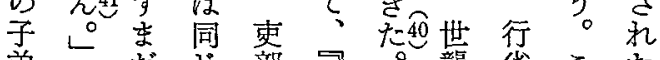
弟し部兄。襲省こた

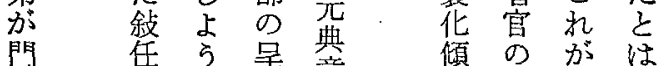

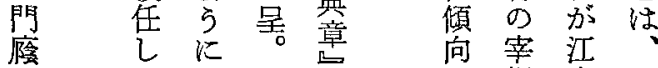
でて を相南の 官 乍南可助級江ら にな命官 、 長の质

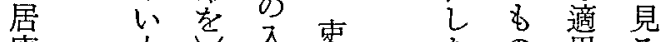
座人さ六事たの角る

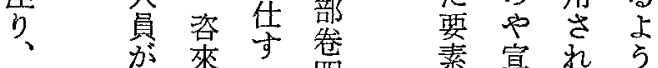

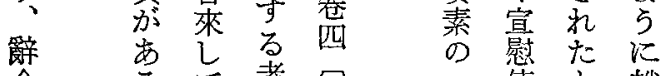

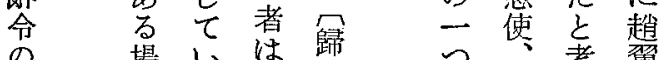

書 合る多附 汇宣党寒 き に 換性擬官求究副祅摘 兄、寸、求守使る 各ら中整よ方た

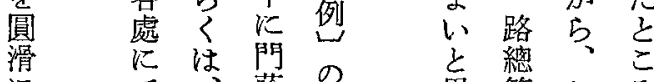

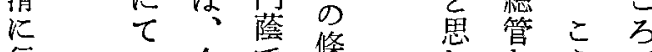

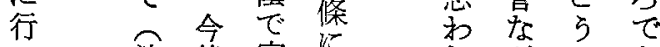
口沙後官に机它亦

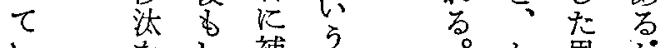

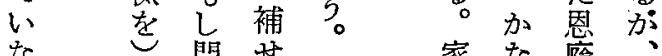
な門せ家な簬

小聽蔭 5 族门制こ

場候でれ宄官度の

合さ官、て品に規

思㴧歸鹰高吉定 わ將せの 菠いて

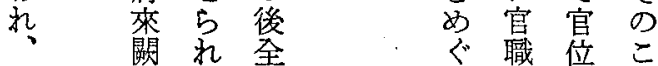
彼

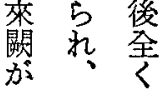
立次

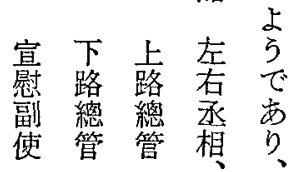
平 曐 ま 政 試 事 棸 左各智 县 知 政 官 事 職 ○ 嘎々

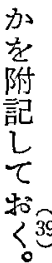




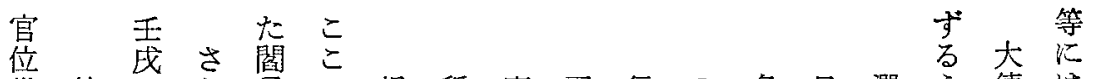

世敕の号承に根稱鷹司行の名日選う德は 襲し條に旨丘脚し復にい如をに法ちもが

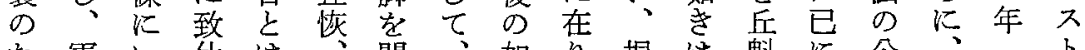

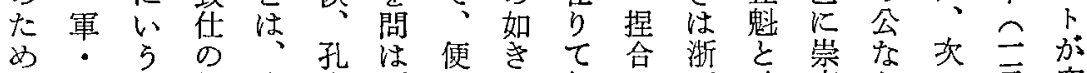

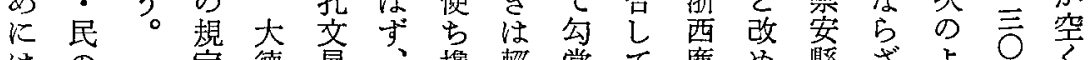

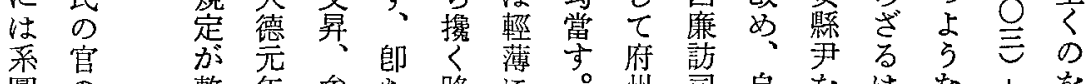

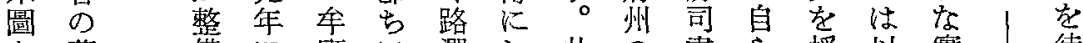

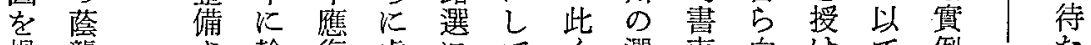
提壟さ翰復䖒にてくく選吏白けて例こた

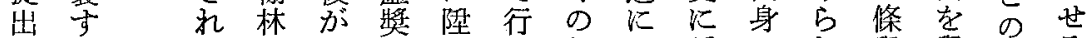

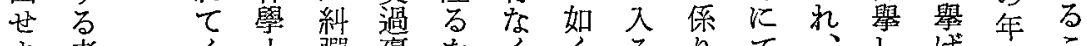

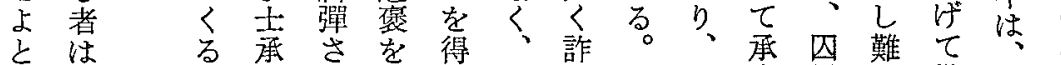

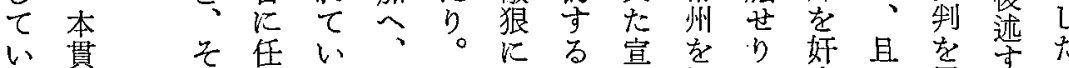

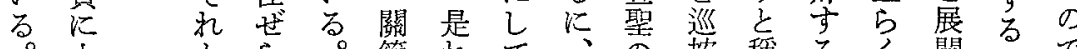

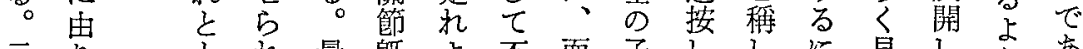

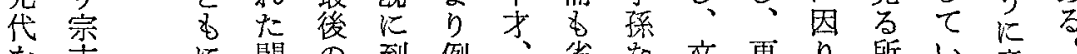

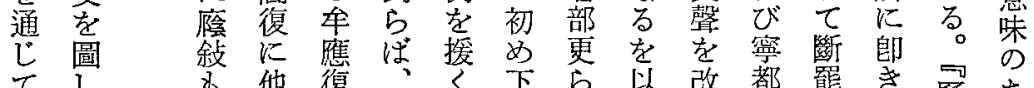

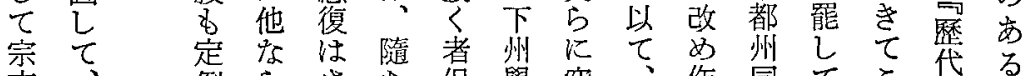
李、例

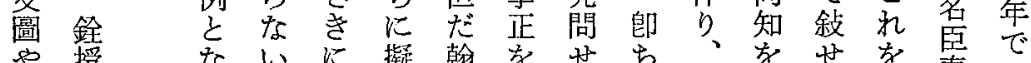

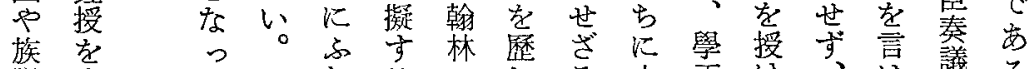

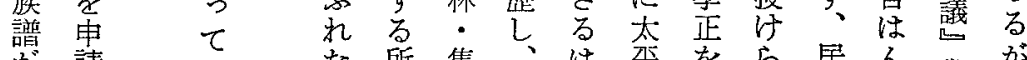

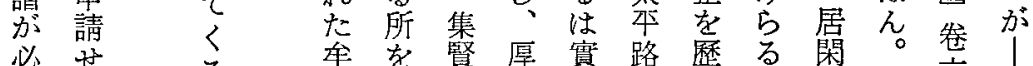

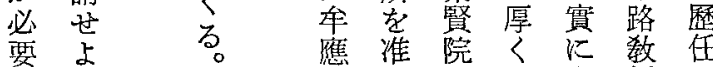
要

ね

理

由

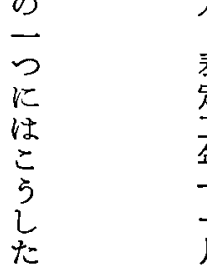

\section{芫}

盘弟

皆

无

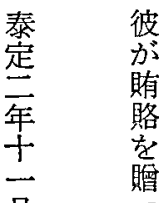




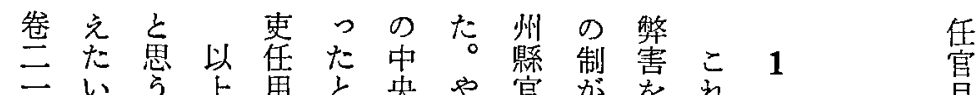

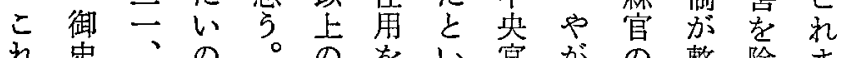
れ史、の。のをい官がの整除ま を臺成でいょ政う廳て世倩くで

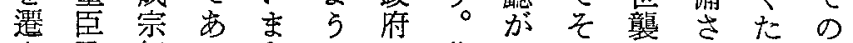
さ及紀る私なの藤地の唯れめ研 しび大。は官手野方省罷てに究 む諸德成こ覀で彪官選めく遷史 道七宗ら任組氏

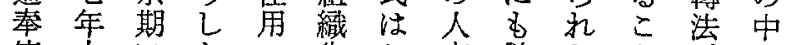

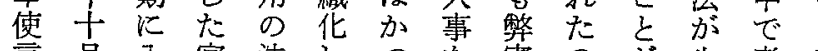

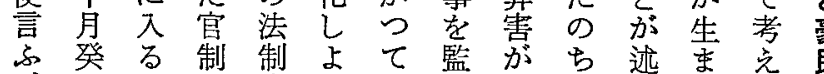

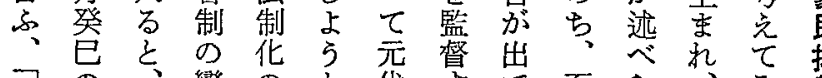

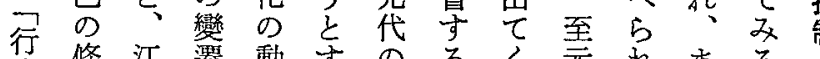

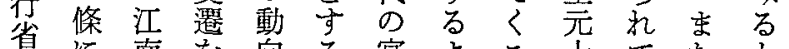

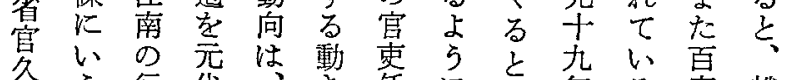

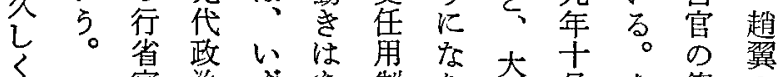
任官治ずあ制り、德月、さ俸翼

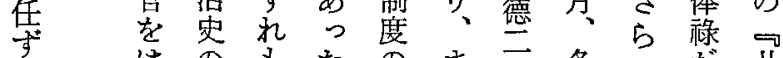

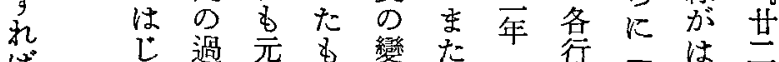

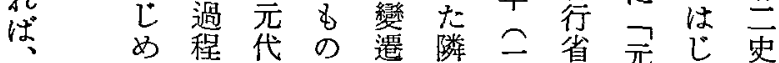

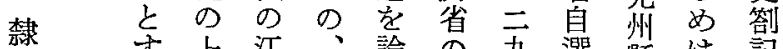
等 与上汇、諭息旮選縣は記

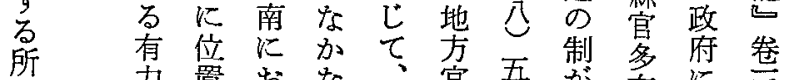

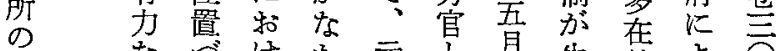

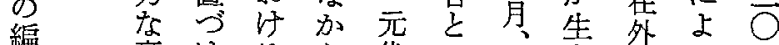

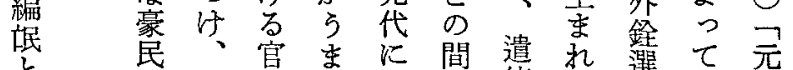

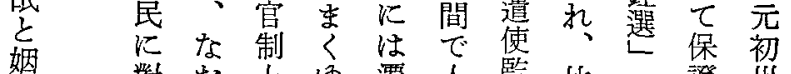
を對抒上ゆ湮人監毕の證州 聯喜科の加事選較條さ縣

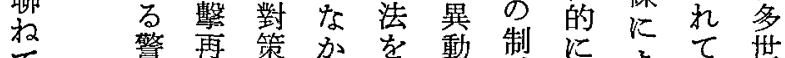

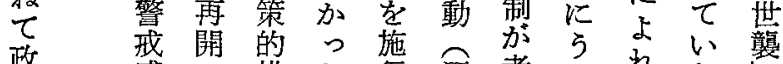
政感へ措た行遷考まれな留

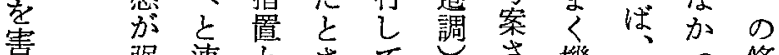
守强連とざてさ機方っ條 ᄂす縝しれ人。れ能至たに

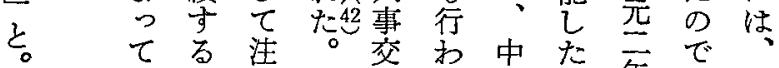

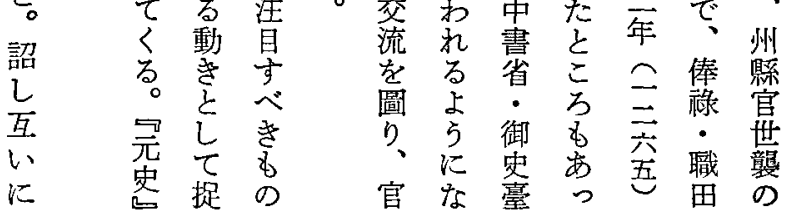


に心政

名ご松力はの

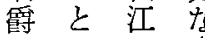

をにの豪元迫元

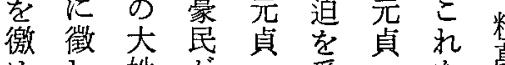

わし姓 が。受・を萬

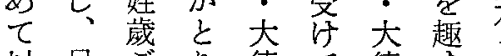

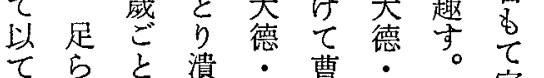

七 占溃皇曹

身机米劣慶皇

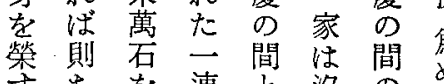

吉。連索沒

。菘漕 要落

今江 し 政劣 し

死田京動 5 殘

し 賦師向にさ

家のにを、水

破中䍌符古た

れにず節る湖

、雜るを時田

又置者合突

たしあす然官

已、

民民良沒に

そ其い落上

のし の党さい

䨖元人好立

包既 55 經

奪納注。机營

へせ死またさ

ばししたわれ

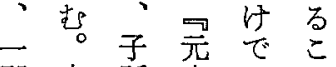

郡克係史は主

の敬筫的なと

人日し卷いな

をく<-がっ

七 县八成た

均无行四盛乞

々吂案王克元 沟

其包。敬 貞落

其深有傳:

害米司俅大時

学仍

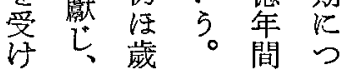

ここさ復張瑞諸光

行江 $⿱$ 成虎捕奉行分 省西 $匚 っ っ$ 使省上 官 行筆 た張 ら宣官ら の省者こ瑄和撫をに 事參 件知最吕子誅よ次省 6 政 近 5 殺 2 換官 汇事論考をさて齐方 西にし忩水提る婚 行またて 頭て案な姻 省で胡市に和さ它を

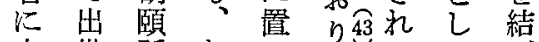

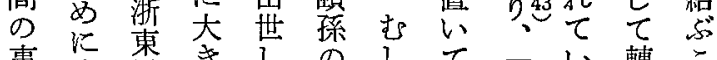
きし 应誅引以元当任衣 波い殺政な史の婎を 紋たは治いにがし通 を彼大色はの極め元 投唯德のず記め尚て

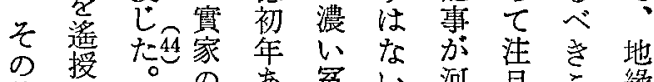

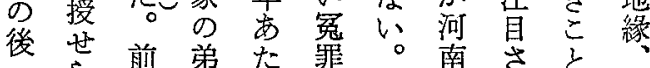
有 司告の謀に攵清省る命線 湖有曹口執ら䧺。㠺關 思訶夢て 行机張丞筆 5 倸 を文资さる。瑄の美狆に 以交に家视。誅清萑たょ

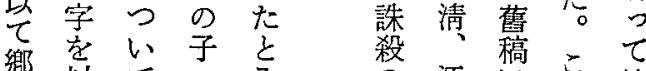

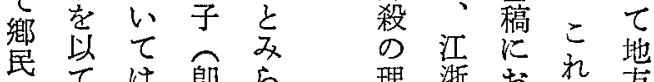
飞ては郎ら理浙打方 散上可占光行い方政 售に農总る は省て大治

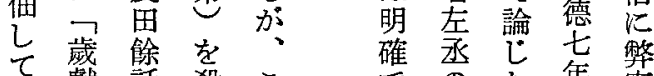

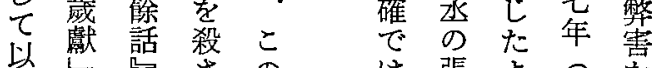
てのは張よこを

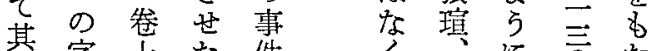

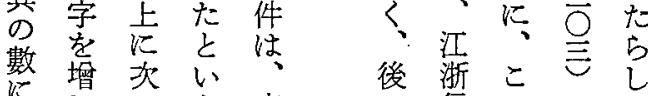

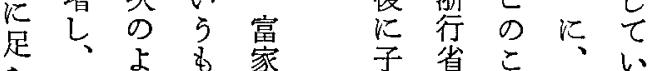

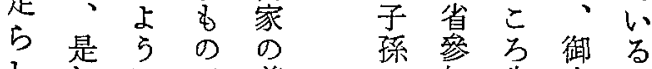

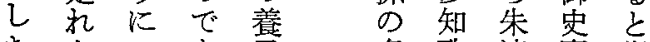
它をい市子名政清臺指 前て う。 


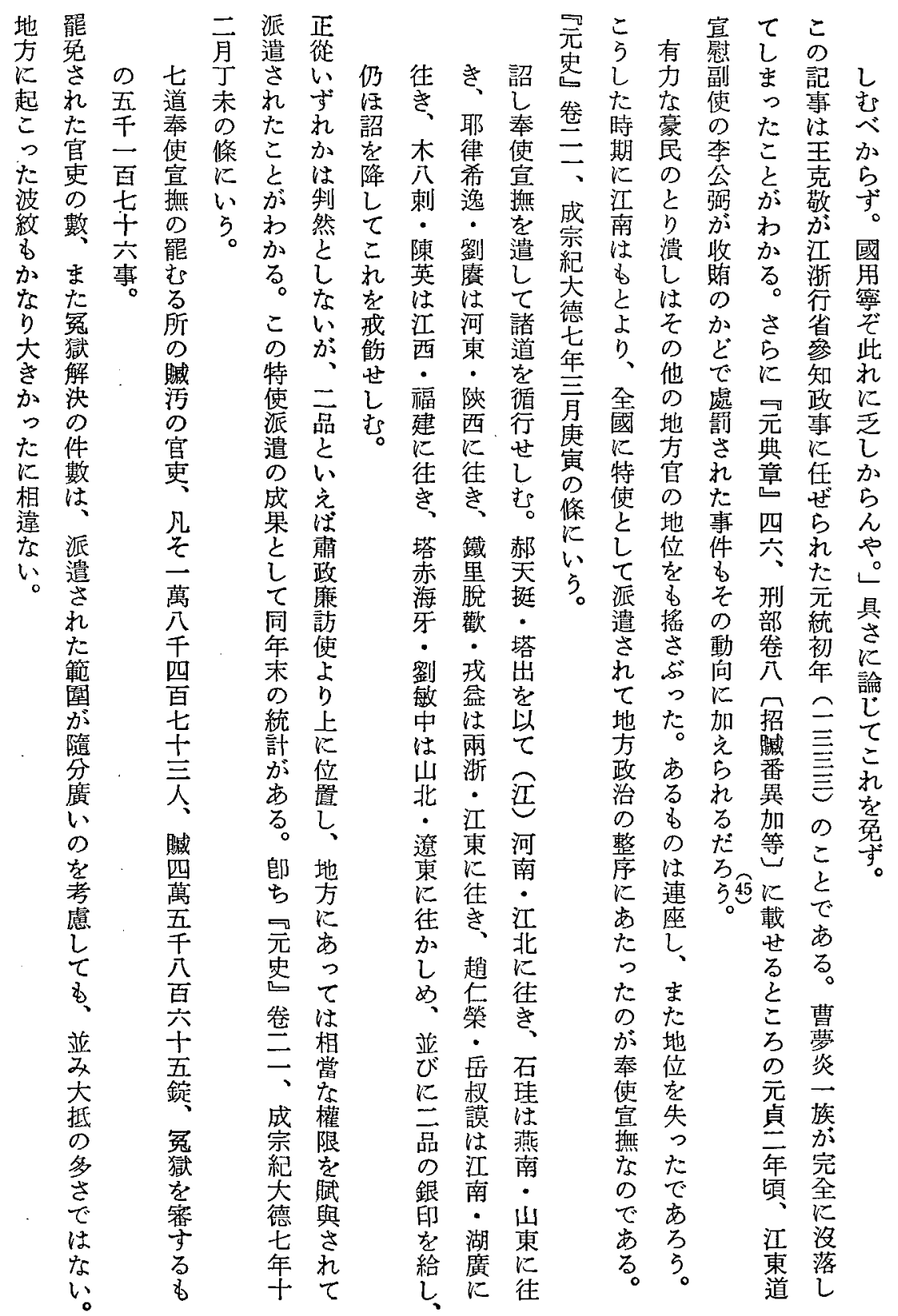


さ

5

府大に如墄乙交て者す大 ・德コしにい結平ある德 州七元違㐫まし民的公 - 年典犯 5 屯てを、據年 縣七章のずに 悓羅亦る正 の月官んすて織たに出

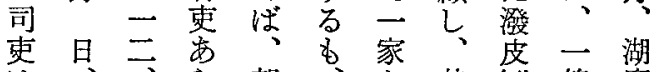
性、 5 部、

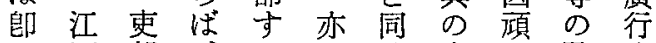
ら西部、るたし家な藂省 土行卷取所有〈貲る富の 豪省六受の司产者豪准

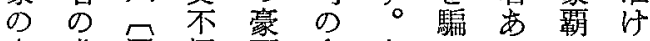
家准要枉龩貪小し、り、のた に汀轉法等猥民包家る 係た人のの既妻皆市中 りる吏例戶る好なら書

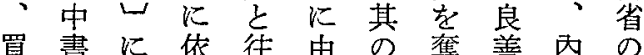
啒省いり來り欺占に溶 $乚$ の 5 て 交 $て$ を $\mathrm{L}$ 非曾。 七咨。科通其受、寺七福 承斷只活甚、官建 克近 せ、然、た强更江 せごん其る有しをに西 らろ。のを司き以充道

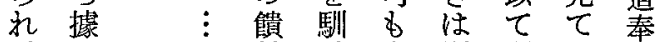
㵝致亦則弱 5 使

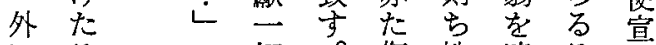

にる

ᄂ 問

一 民

權 疾

豪 苦

江官

交

接 呈

乙

民西

產 省

をの

侵 咨

ᄂ, 所

內 $の$

に 路
切。侮性凌る热

の 各る命 ᄂ 者热

物處所害衆古虽

受行爲傷学亦巡

る息。合亦行

花非言赛䁣し

得 9 理 5 をて

ざ大にに害軍江

ら小民勝示役西

し官を系、に

む吏害べ妄䌖至

るにしか交職り

に蘩其等橫充諸

々 禁㸺。橫充諸

はて惡官范ら

な、学興る言

し 親縦としる告

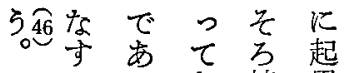

こ主轉用こ そた た機しで

警さで訪こ使 戒れ亦机宣 しばるつと撫 なこ。つ妥 け之こあ協果 れ前こつした ば迹でたい た なの具た 5 上成与役 な 5 万相 割 加上 5 豆㕝 た行り一依兑 の省 世世存元 で官の代专み あが豪のるよ る久氐時こう。

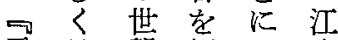
元地壟經よ南 典方を過っを 章に公して軍 漞然てひ事 五乙学的 七ん認現ま源 刑でめ 地 ず 制 部るか有治し 赏 間 否力的た 原古安後 九 婚 は・定

口姻、豪を始 豪關元民得め 朝係朝のては 紅を政子き現 粉利府弟た地 壁用にがが 迤元稚爾古 北地ての来者 出方大年三些 種 政變砱干豪 治重に數 民 のに大さ年を 條䌘なし、地 蓑問吕々方 いを題かる 官 


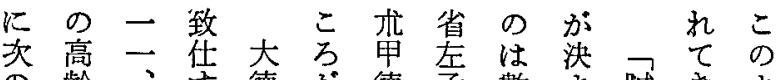

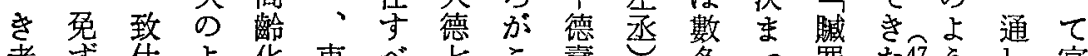

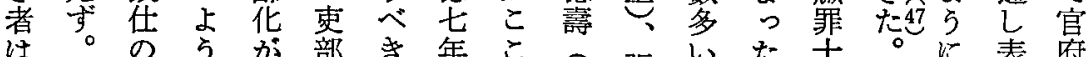

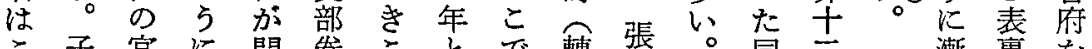
こ子官に問管ことで轉誫。同三潮裹を

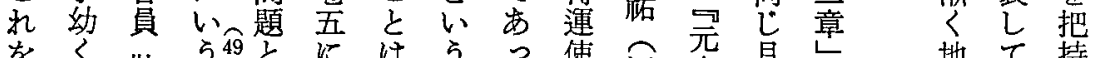

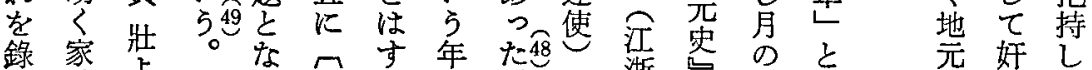

錄家

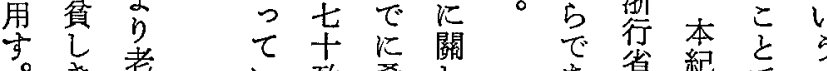

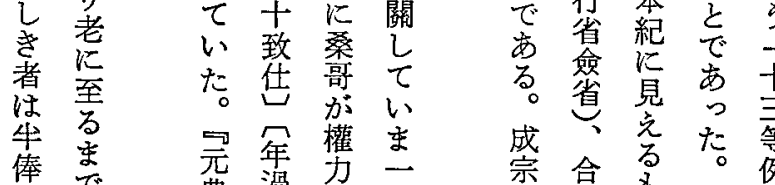

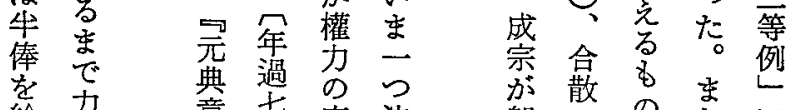

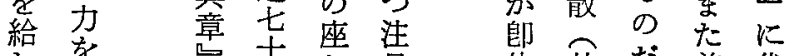

乙宣故慁位甘だ前代

其宣 二依 5 乙

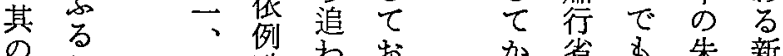

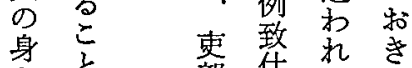

多部茌杂点

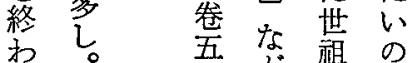

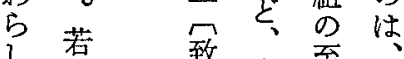

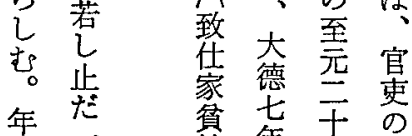

年た窟䒨干更

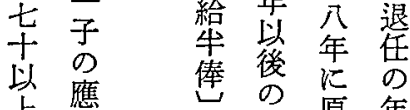

上隹滋原年

雖噔載例的等

安應势学定磼

精き完らぬさ

力者畠わられ

未者恩收れた

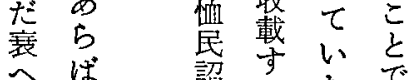

代㑇すいだ

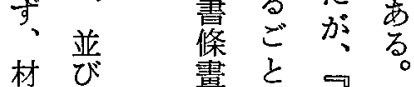

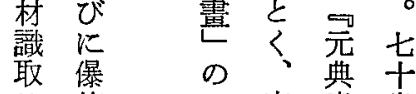

る゙使棉草藏

か 省名朱 新

与悉、清乙

官章阿 - 以

吏 政 里 張 䁍

の 事 瑄 罪

䁍要江江

罪法浙續關

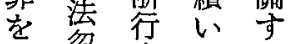

め鯬省てる

兮魯音こ法

議 西政の方

論西事年施

偝京事行

活蔩亭罪 れ

に慰鹪翡た

な便 江 か の

? 浙 艺は

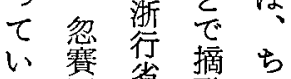

た因省怔尘

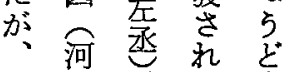

そ間、替

の 路 安官使

行洋祐位宣

き魯つの撫

着花江高

赤浙 $心$ 派
豪爲簿

民 書

曆詞捏

多訟合

结学。

倱起隇本

5 乙

礼、更

て 久

い儿爲

万< 5

甭 衙

吏 門 兄

に壱

對占子

守め姪

取 鄉 親

締土戚

りを人

が 出 等

集離府

ᄂ る 州

本肯司

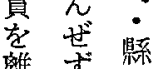

離 江

れ: 置

遷导

轉葛

世搏

傾 ᄂ

向占 
きと立り 官突

わ取し吏中り從や國官あ中大南

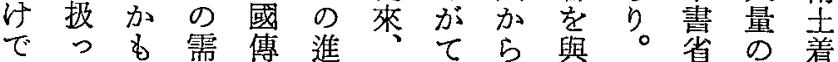

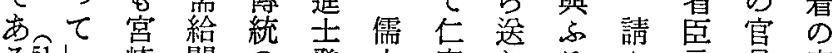

る51 崎關の登人宗りるふ言員官

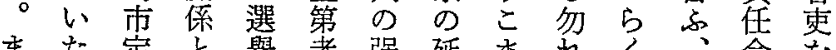

また定之舉者强延ま机々心命を

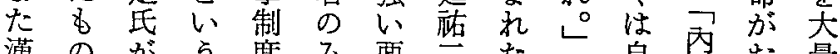

漢のが 5 度み要严た自內扰量

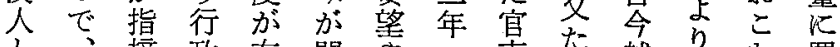
主摘政有問邑气乘言越旨な罷

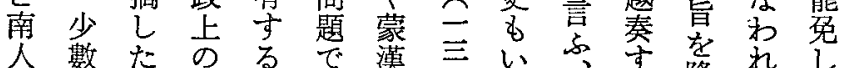

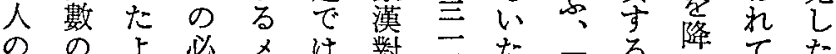
登蒙亏要り竞吾た外者してい啳

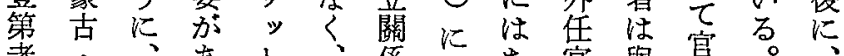

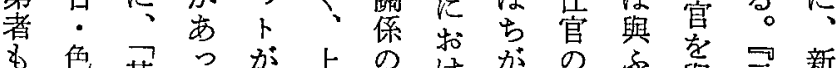

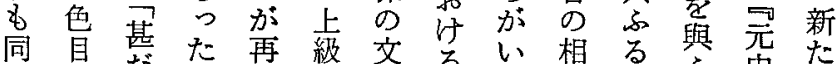

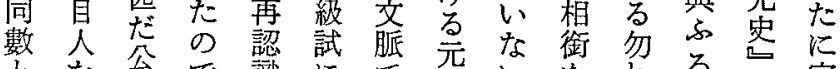

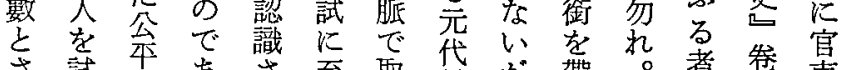
さ試平市さ至取偮が帶

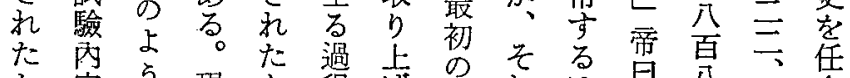
か 容 5 現立程壮科れは公武命

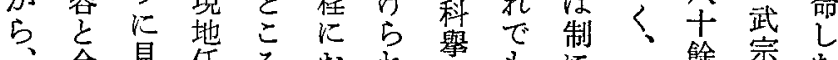

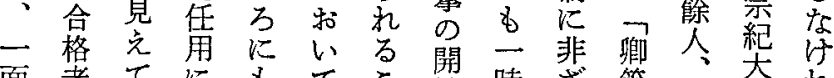

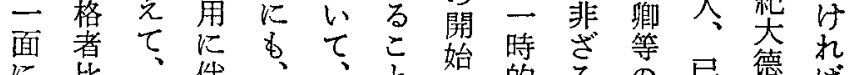

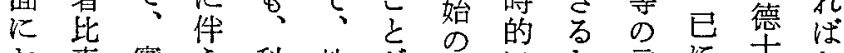
招率實 5 科地方伏にな 言に士な

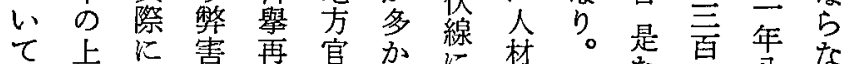

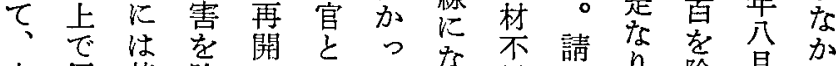

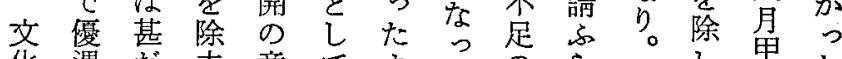

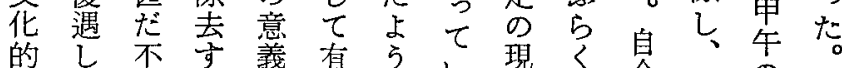

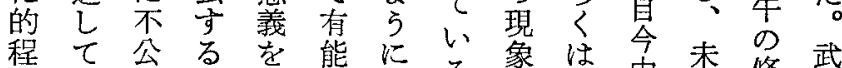

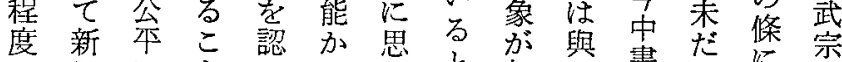

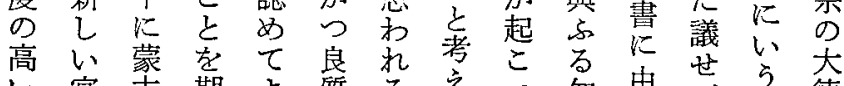
心官古期上質る兄っ够由ぜ。德

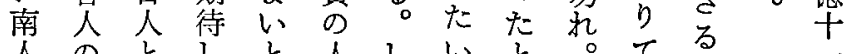

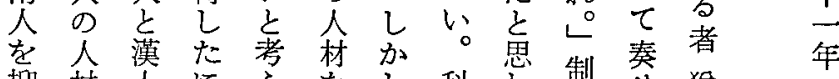
抑材人に克を科尔制替唒年

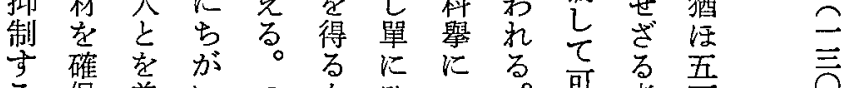

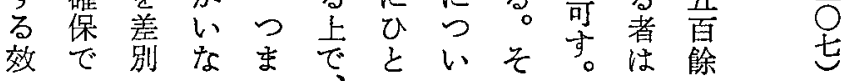

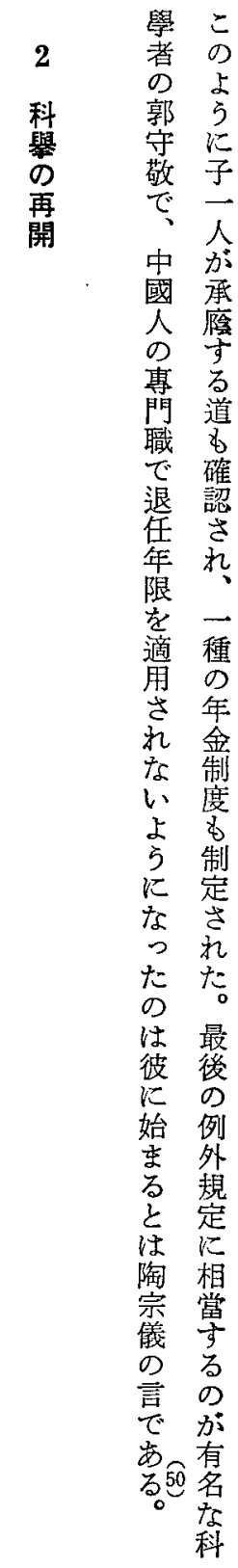


元 江 黃 はら る

科年西河推の、科 擧 $に$ 行

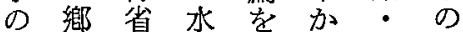
開試參利必 5 府登 始に政 事 要の・第 に合と業之ち州者 と格なにしに・が む貢た縣縣地 なは、獻は耂のの方 5 嘉 彭し才゙、學 官 制興庭たで縣校の 度路堅こ亦丞の重 上總 更方學要 管 溫で篮正 な 關之州有可圭、巷 連惊今名能簿數給 措つ、ひでに授源 置て至は亦任、と にい正のつ官教な つる四らたし諭っ い。年に。たなた てに中賈文 どの ふ 鄉 書 魯の の は れ 試左名 ポ 言 七に丞高あ ス. 找合に本るトま き格拢人程やで た擢度畫好 いは坖は院な 皇 酔机史出出少

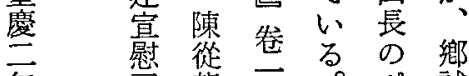
年 司龍 公管試 士 同敒 七學不学 司皇州春吕を格 に な 人泰 5 定 科り、至初方恩受會

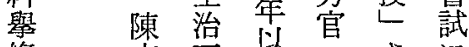
條宗严前へさに 制義年前進れ 合 上注吉る格 か 潘 鄉 可ここし 公 梁試回榔衣衣な 布 今合試名名多 れ 後格に合恐心た

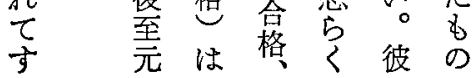

るてて 品をささ地

ゆは見れ㟧で南を く下以出た年へ鄉案古 わ州卡专百試最果 けのはこさ人が采た た同正とき合實期し 知七がに格施のた 方品でふ心学吉威亡 當用和和淳心 然意正る。た だた のさ元。可气年へ こ杂品

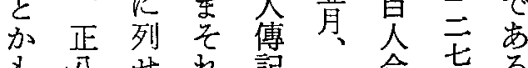
も分世的記 殿合苜る れ品られを資試格

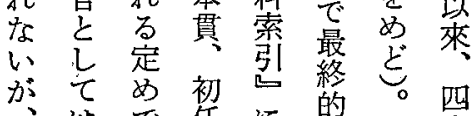
、はで稚に的こた十 正下州官は、 品制た そ管ン合年 の官がの見が格 ブ 初あ、後の斿者う

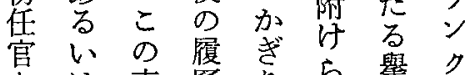

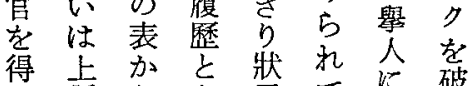
た縣 ら立元て破

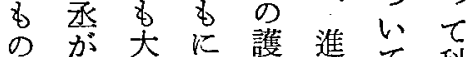
が用體第都撒隹て科 そ意々 $\mathbb{N}$ 沓及 舉 の芑れ表兒第翌 再 のて確 し 除進云開 階 認て 梯たさ示て出にれ

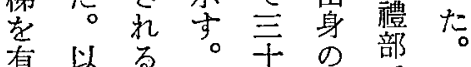
有以利䈗六合方延 年正任人格行就 昇功七官 0 者わ元 進党品心進五れ年 守重の最士十る公 る初高登六會月 よて任で第人試に う昇官す者方を全 で進と從の決受國 㐫し六名定活各 
富

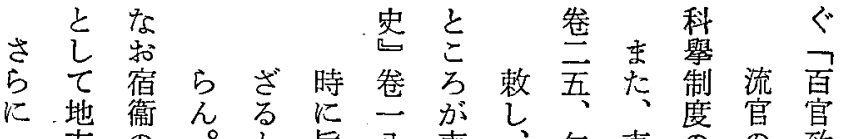

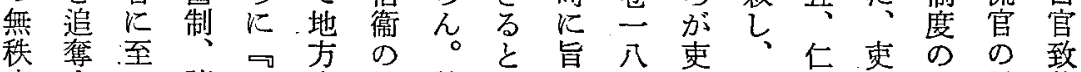

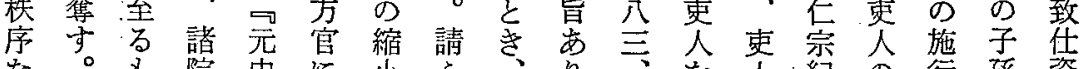
な。完史に小ら紀の行係資

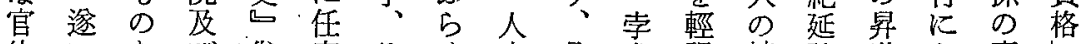

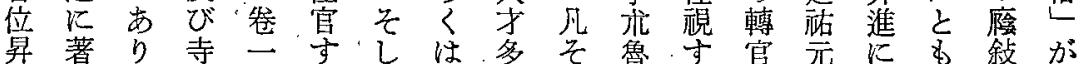

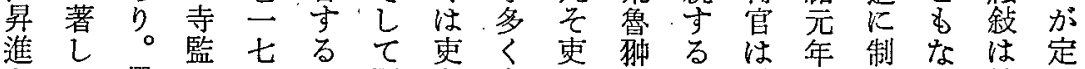

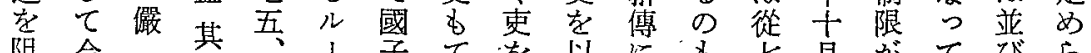

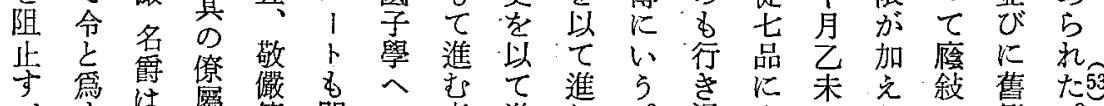

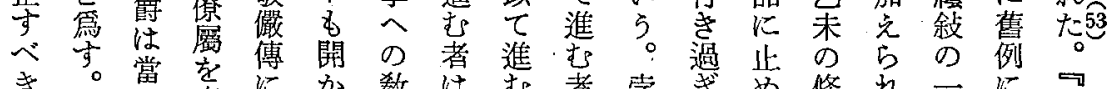

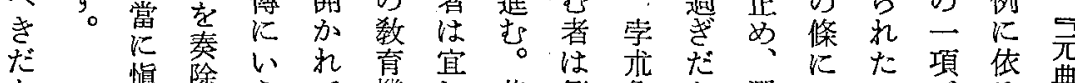

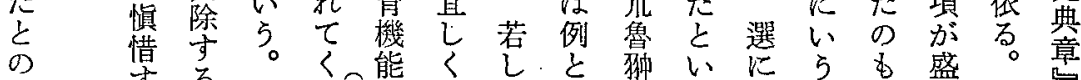

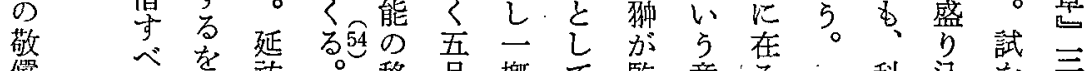

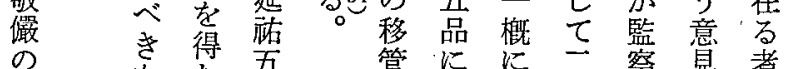

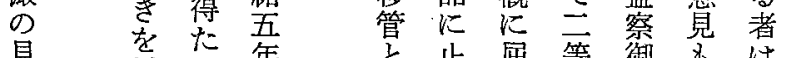

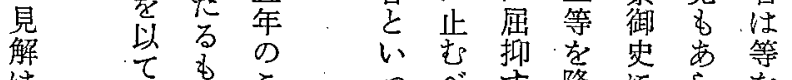

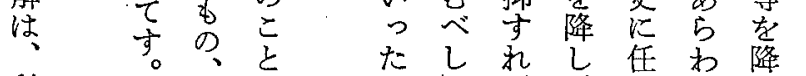
科藇會歳

施

後

な

れ

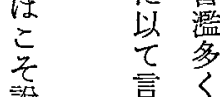

說言く

的篇富

た 乃或

の 光

で奏 賂

あ 請离

る ᄂ

悉 進

$\sum$ 项

京大

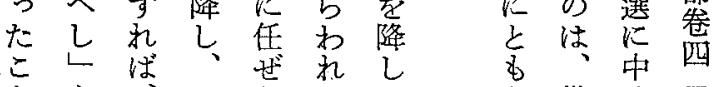

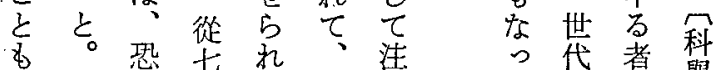

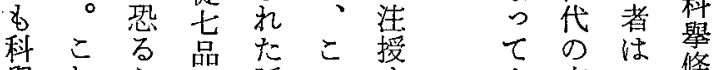

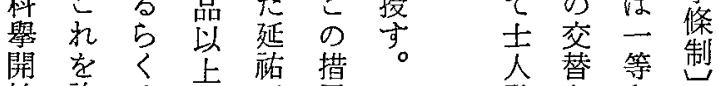

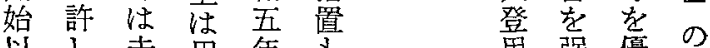

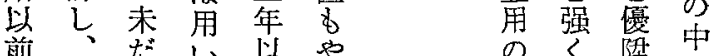

前、大心以户

加因天る後加

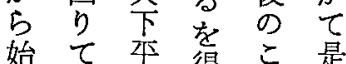

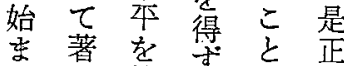

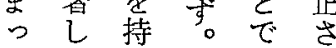

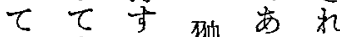

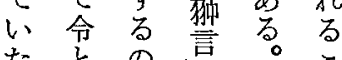

た豆要言。气

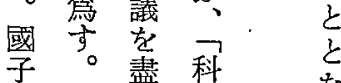

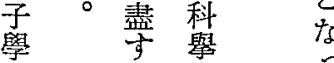

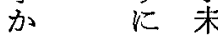

与 足 $\overbrace{}^{*}$

the

至

点豙

道意隌虫

加識。券

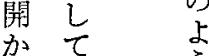

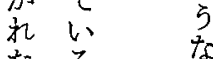

落总度

点占條

满䓔西

方完 
乙 た 次泰的進中

万的の定代出央

七 女詔め記名名し 政にに以秩天次气

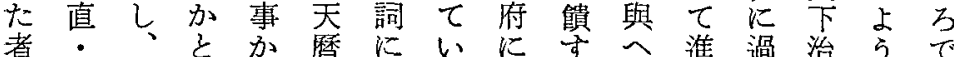

の契諸疑ら年轉た入るず热き市に元

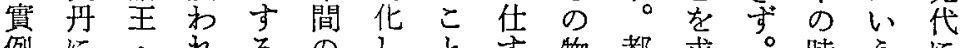

例に矿

次て馬。中料

に名圥國がる實はばつ令亦意に

示蒙分更人あしで制なてのた省省か

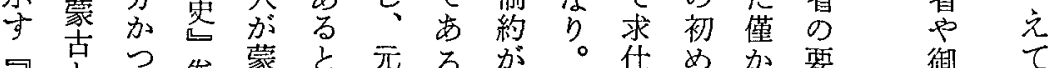

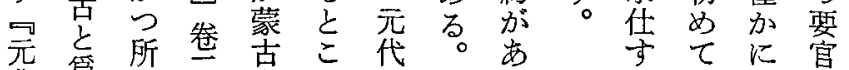

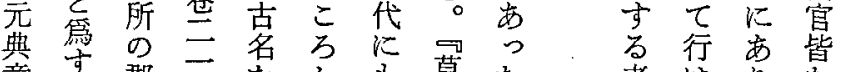

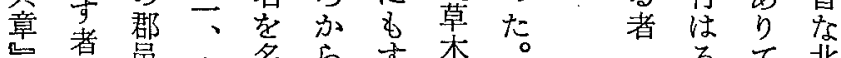

九住总大名占夺杰

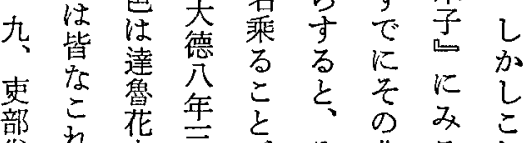

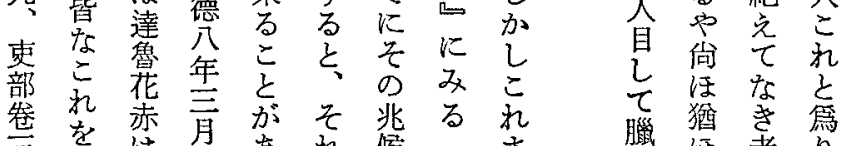

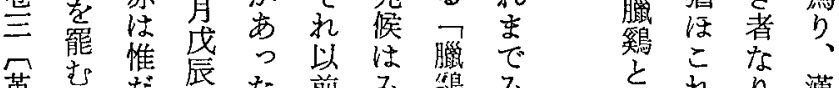

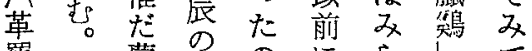

罷蒙條のにらして

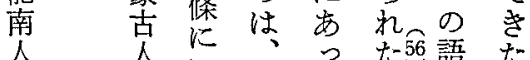

人久W、。

澾ををるてている

魯 角 。立は諸明方

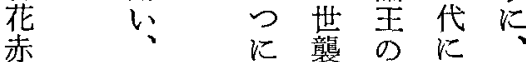

赤 三襲分に南

海之地都中

見に 5 な

b ᄂ ᄂ b 長獵の

れ行官官人

る 例分わ運令

に地机世動か

依にて㢣に地

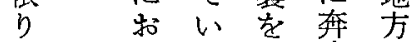

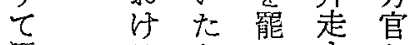

要学文守を

代任みる当中

す 官 $5 こ$ 江心

9 礼充西

の 要

漢索まるのか

人 あ た 方笑

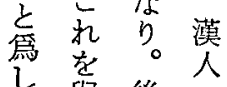

它與後 南

以宫炕南性

乙納人探

相粟性用

相こ学さ

れ獲中些中

㱖を功に市

㗱求可三

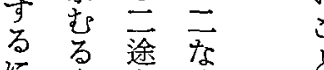

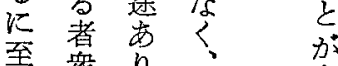

至萣 要其多

蓋艿富

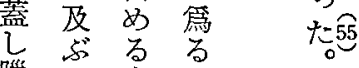

臘飞者を

鴙、草

之亦々 る 尔

はたに者子

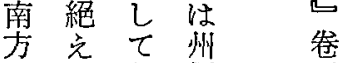

の $\tau$ 此 縣

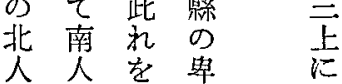


元代江南の地方官任用について

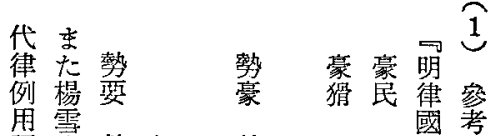

语霍勢上な勢る百民學考

選注のうはい姓の解た

釋明感上。威なの内吼

以代勢き豪勢る身飞飞炕

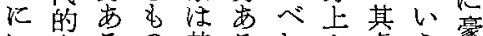

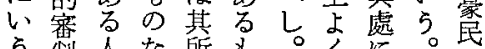

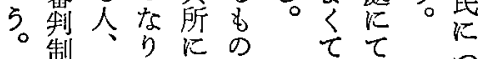

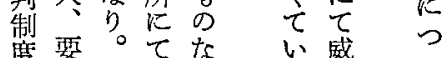

度要。てな京感い

乞き の。岁唹て

二用多占方白

九当交店语

七な ま貴事解

分役を余市去尔

の货言緣市示夺。

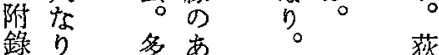

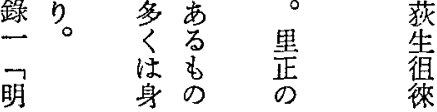

3. 2

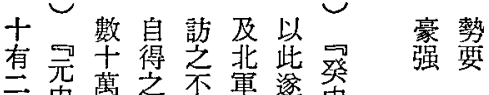

年史禹色獲至得虫里指指

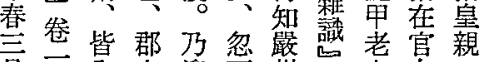

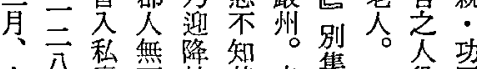

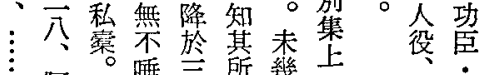

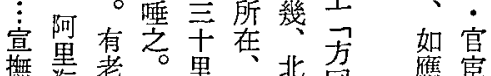

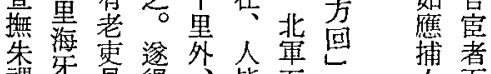

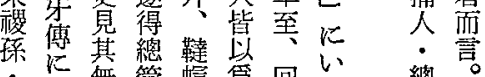

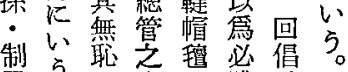

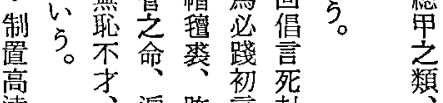

蔃杏遍跨言封

想極括馬死疆有

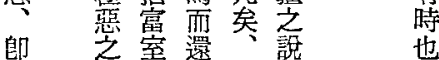

以城銀有䗅獎括
れあ民と

てれの政この

無、存策れむりに大

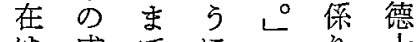

はなは否で述舊此り、士

な刺良怘䂛杂問年

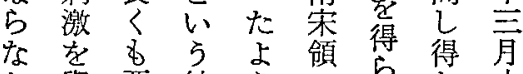

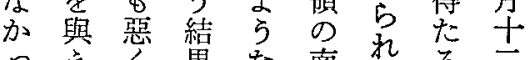

たた党果な南㤂学充

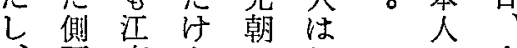

、面南をのし

宋がの み官た

吕あ㰵て制た 黄峾

明 5 元革に夻ら

へ。活代 人元招據

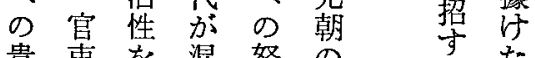

貴票を混努の铻た

重住與迷力地方童

な正党し た

渡め心例必配請道

しぐた外ず機詞道

をるし的し構師电。

た朝征時成中方

政服代功に違察

考府王々 乙進制知

之の朝考た出涂し

る樣の党と莯た

の今出るは果泉る

でな現必言た洛に

あ試そ要いし批建

る行の快范擬昌

錯すなたいすす路

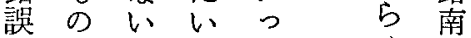

はがをとたく城

や國思こ少縣

は沶。古市合魯

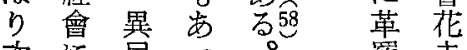

次火民口。㴰赤

對族た 吉伯

時乙政。落じ顔

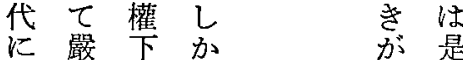

㱍しでし相方

承くの我應南

岕は豪々床人 
6 35

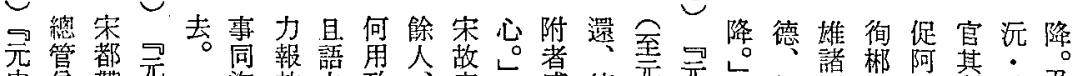

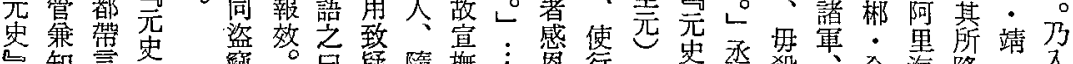

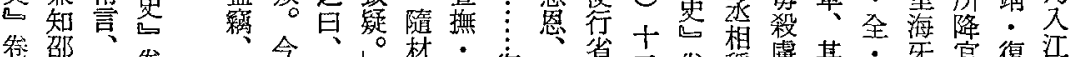

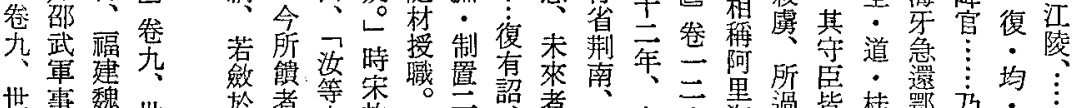

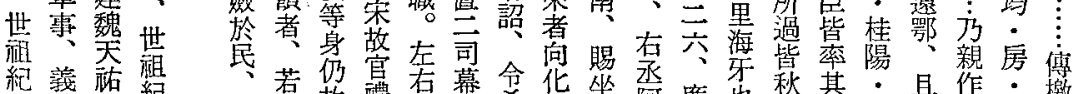

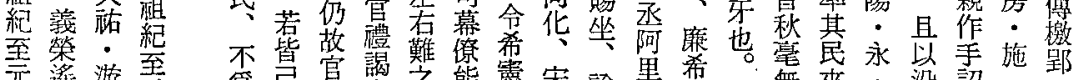

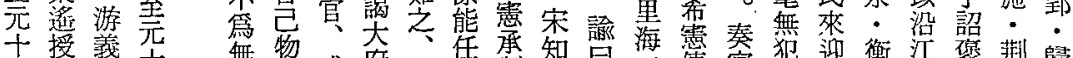

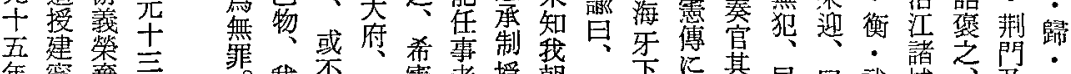

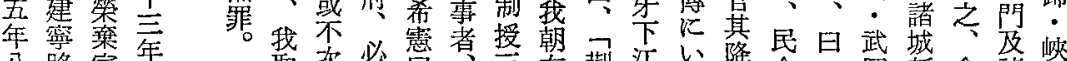

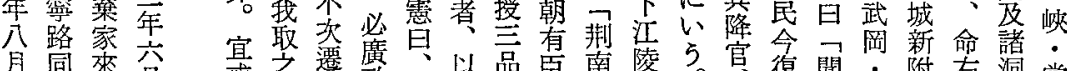

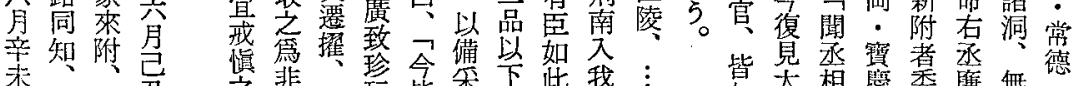

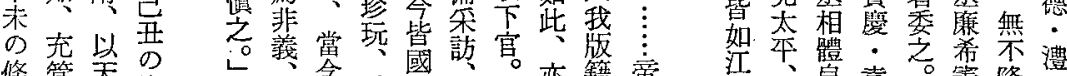

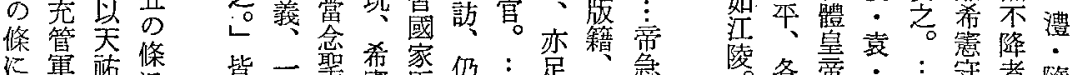

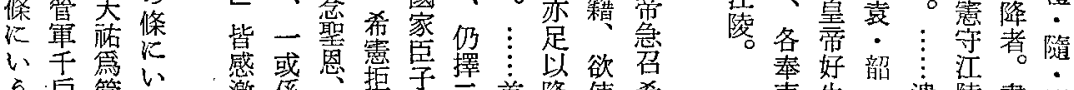

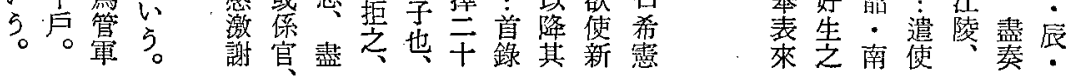

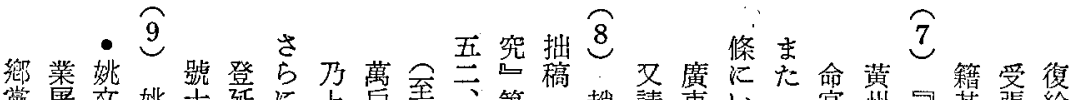

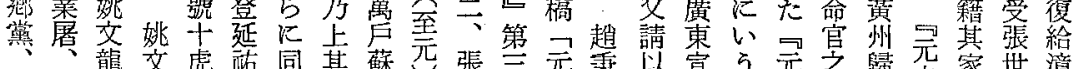

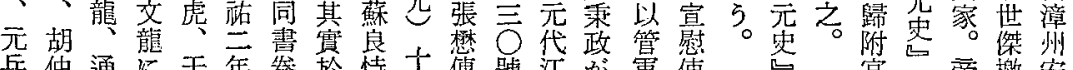

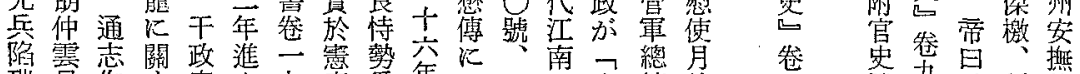

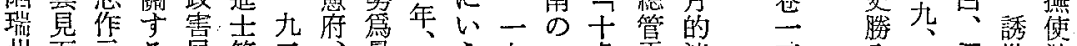

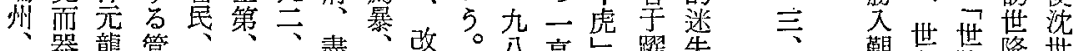

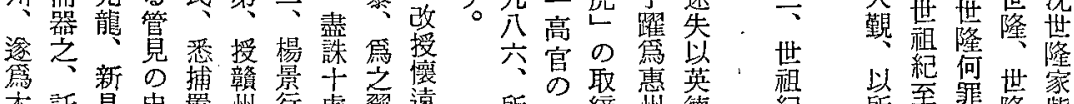

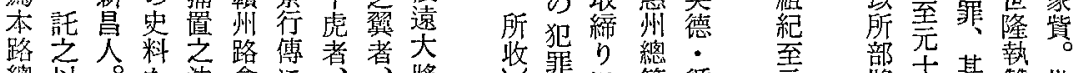

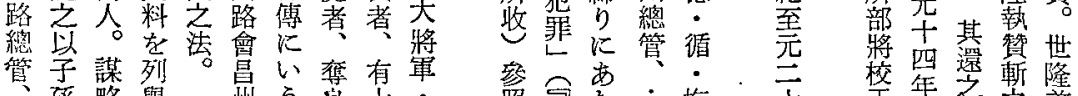

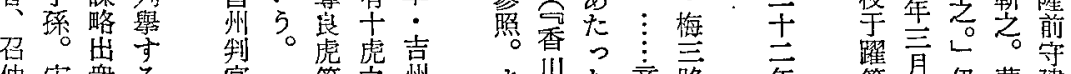

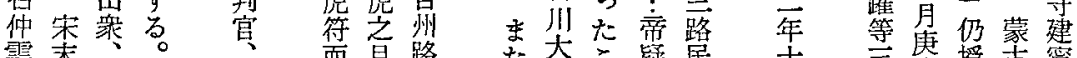

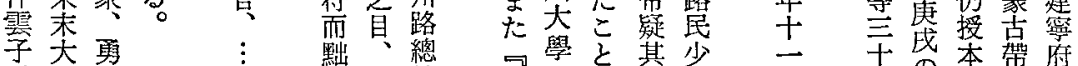

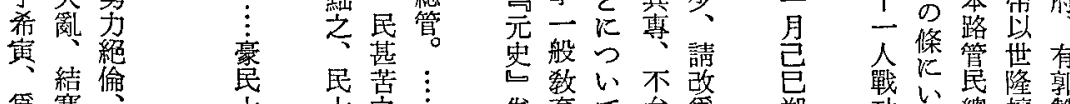

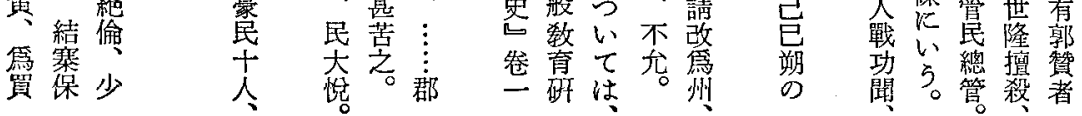


11 $\overparen{10}$

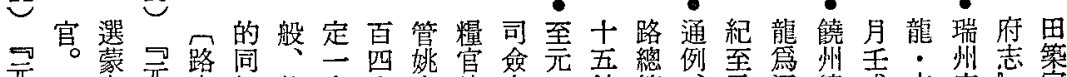

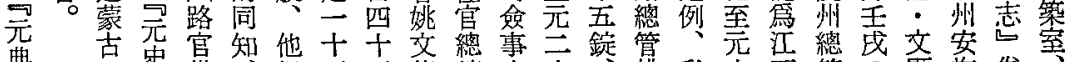

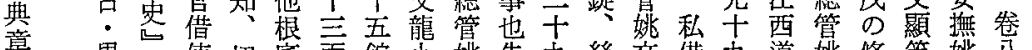

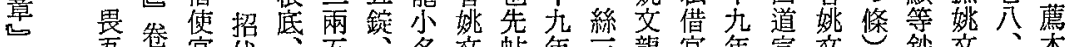

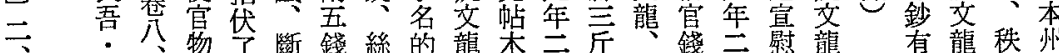

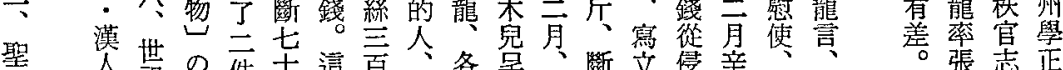

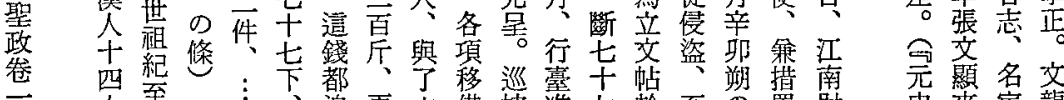

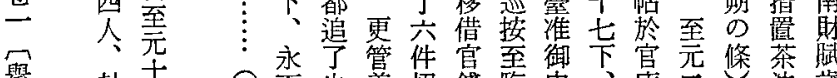

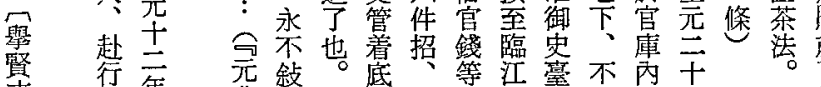

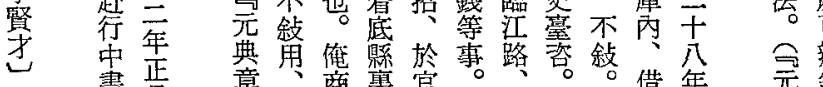

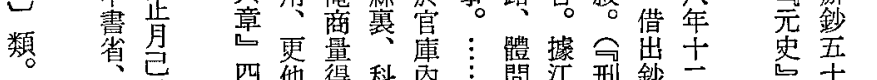

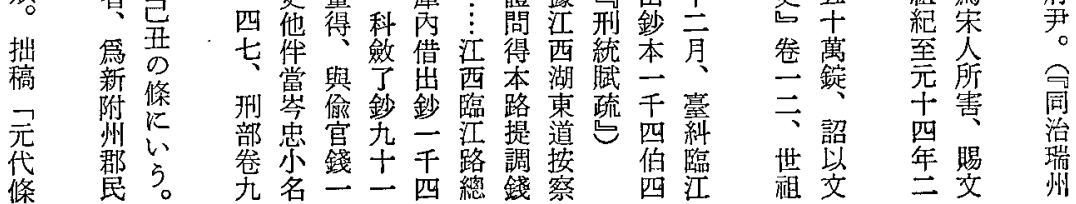

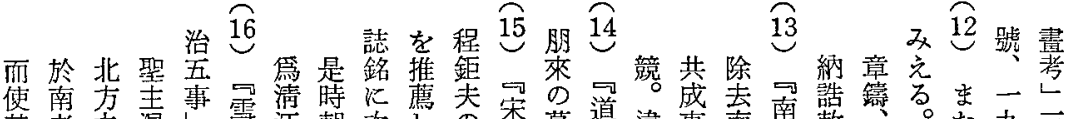

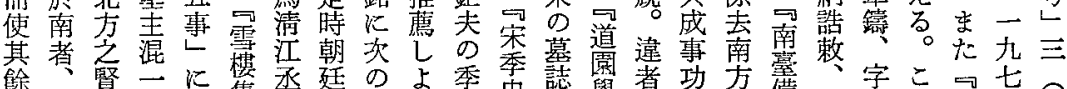

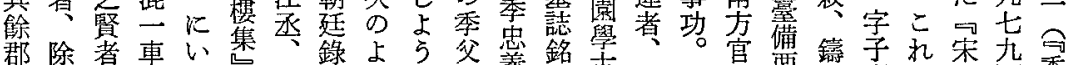

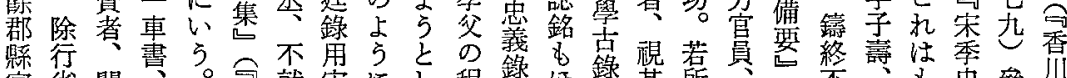

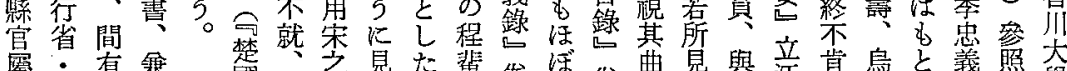

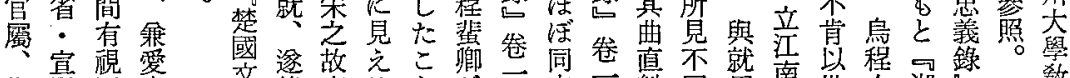

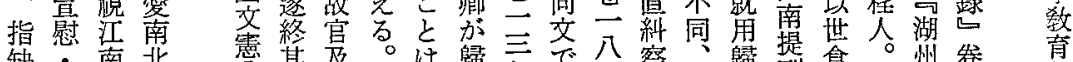

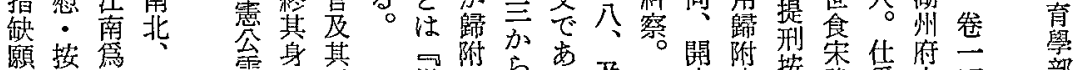

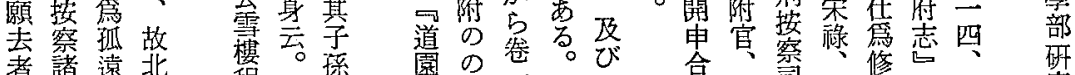

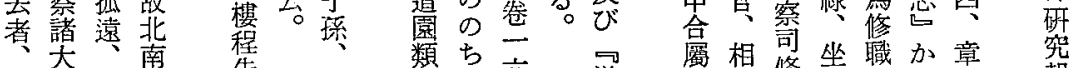

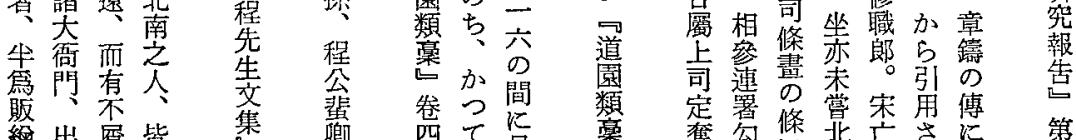

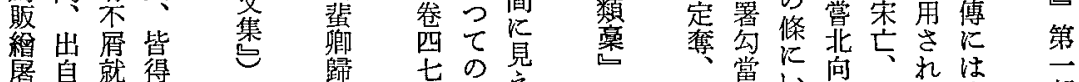

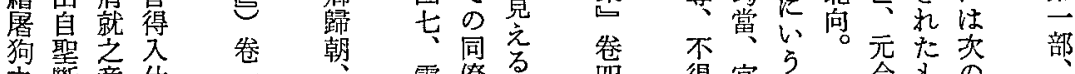

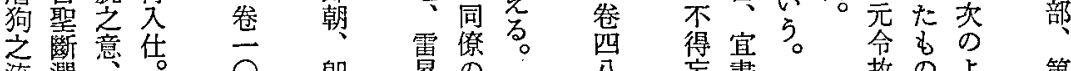

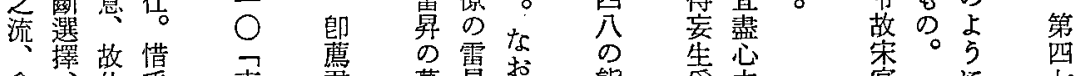

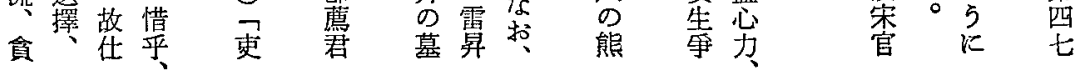




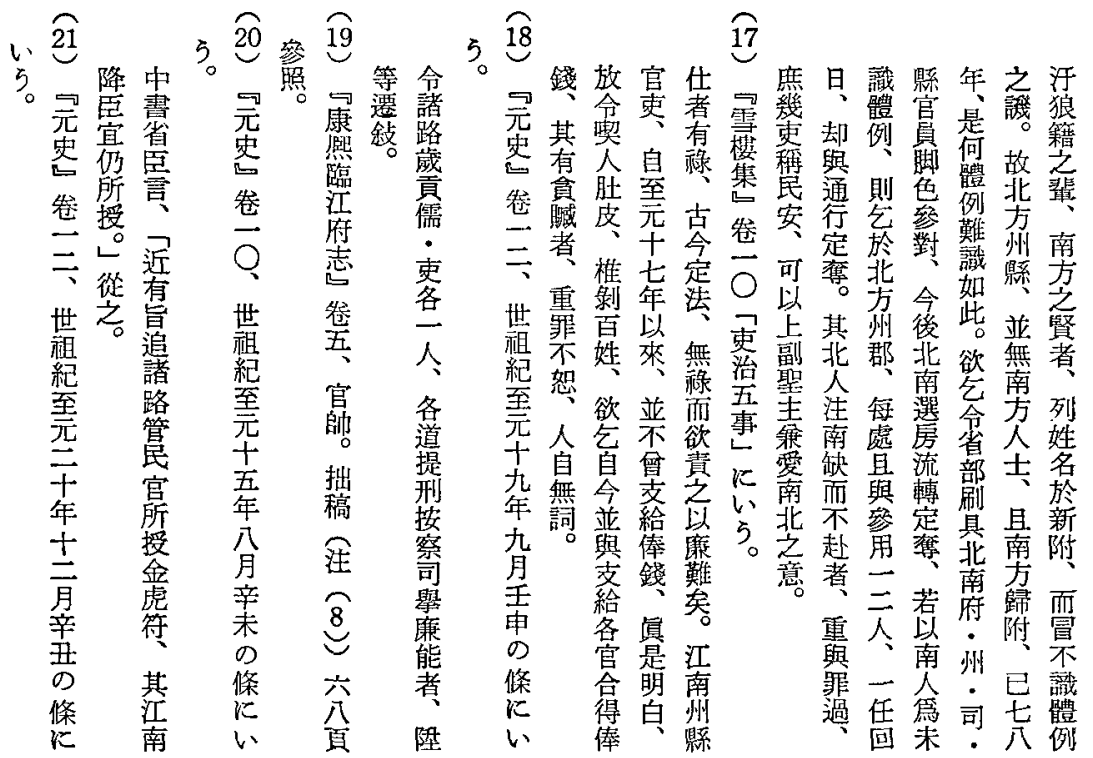

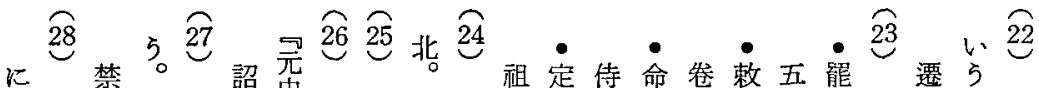

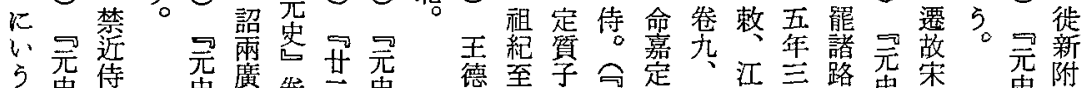

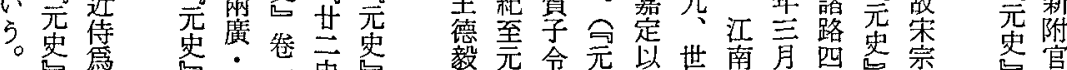

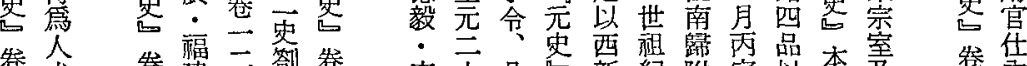

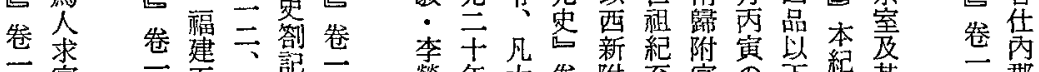

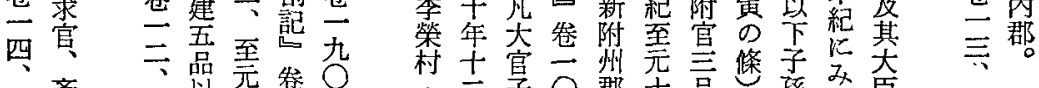

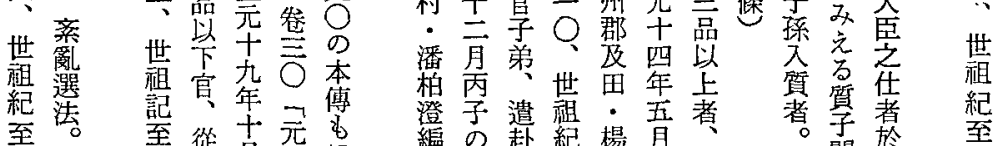

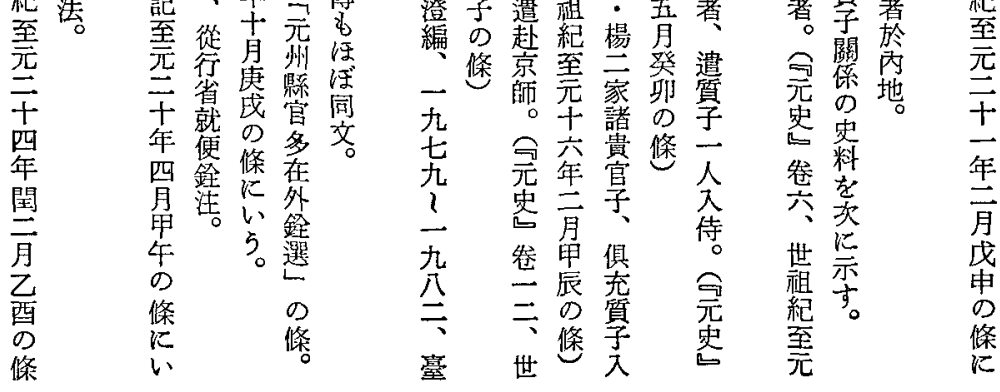

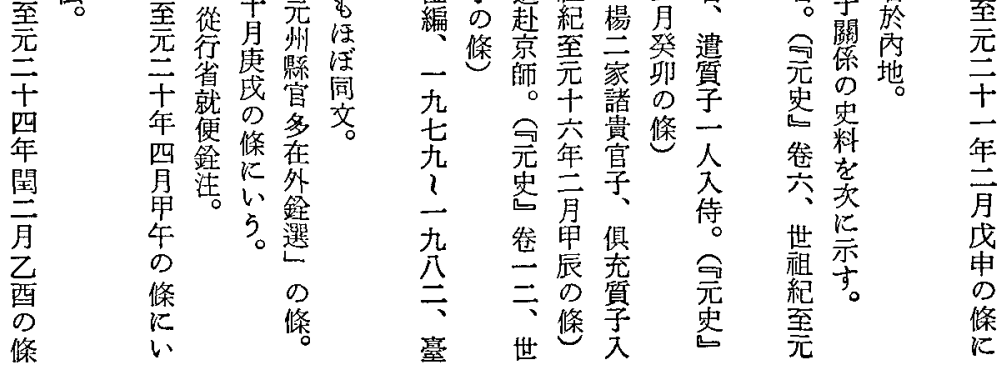




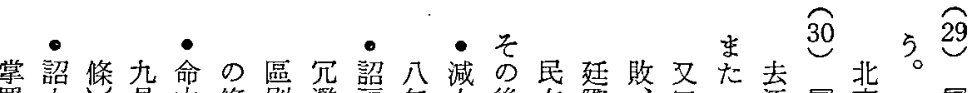
院畫

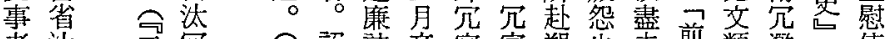

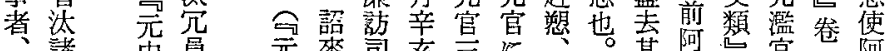

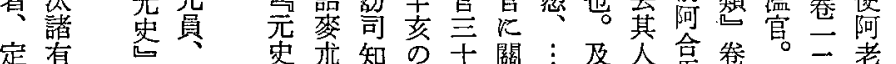

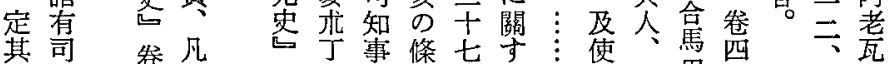

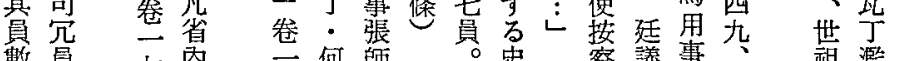

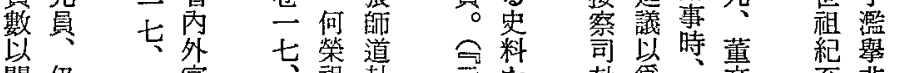

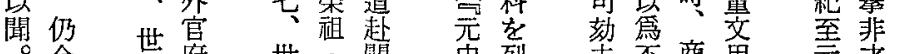

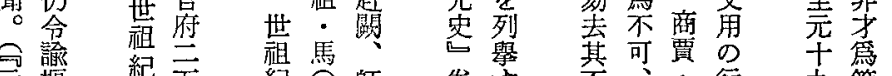

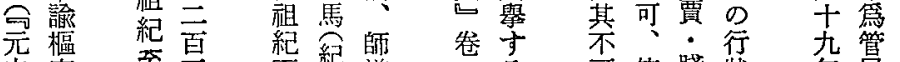

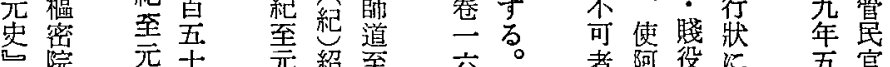

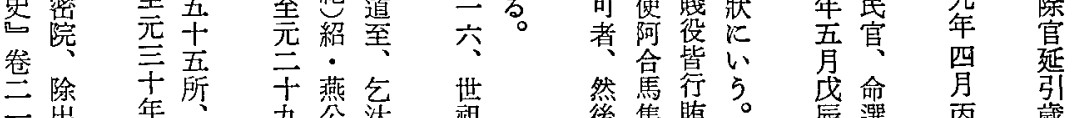

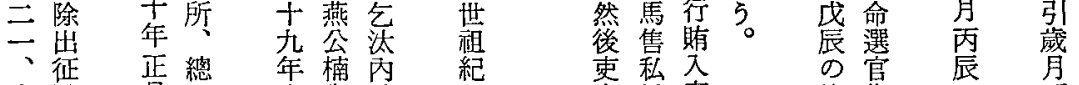

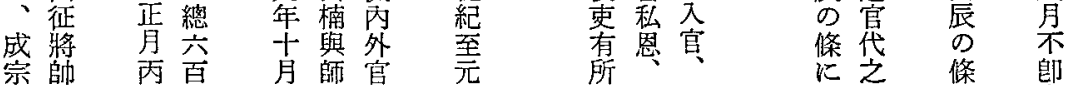

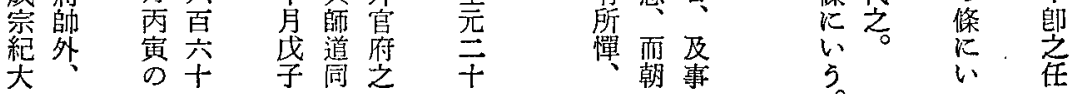

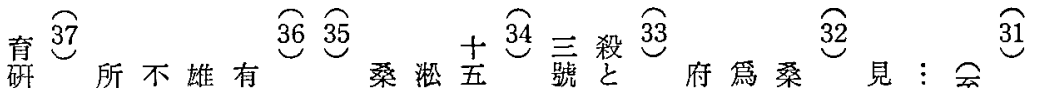

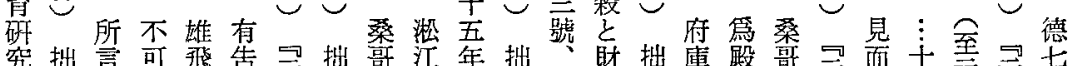
究拙言可飛告坖拙哥翯年拙

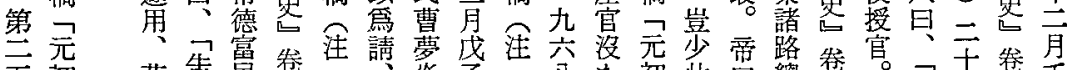

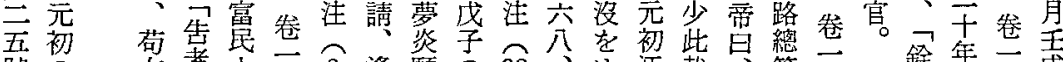

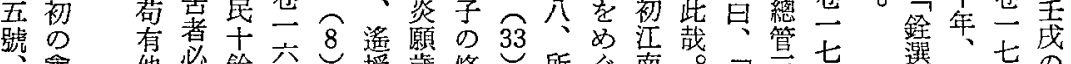

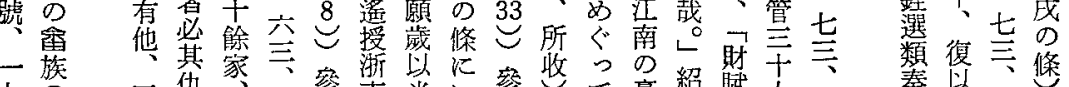

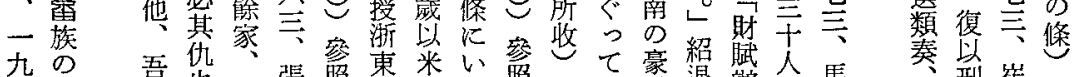

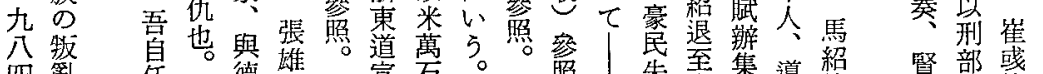

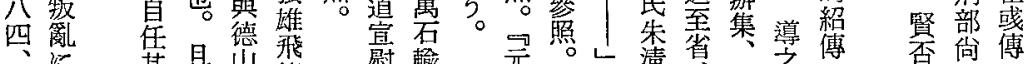

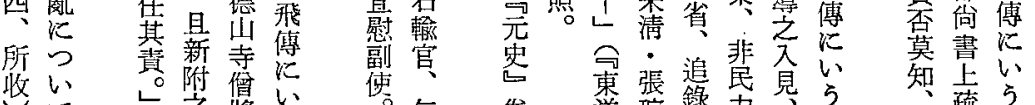

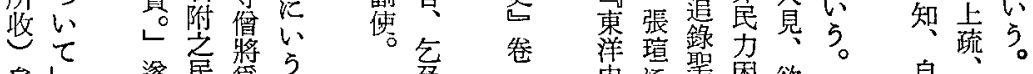

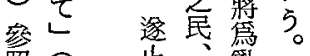

照香 齿賞

II 徐以息

大 察靜菲

學㝎鎮兵

般果討

呚 如兵

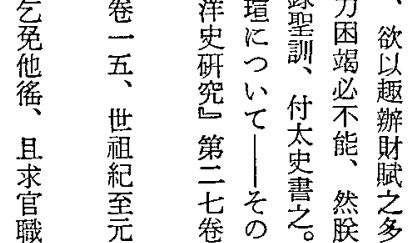

自 言

竎 時

品政

上公

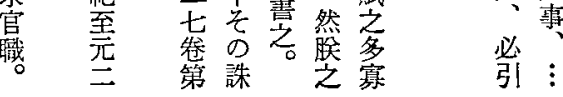




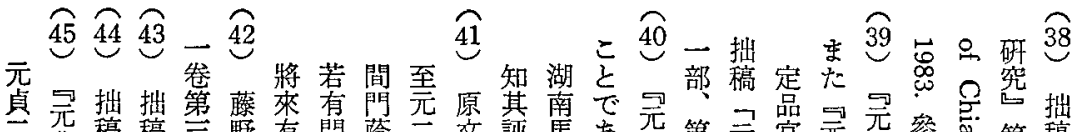

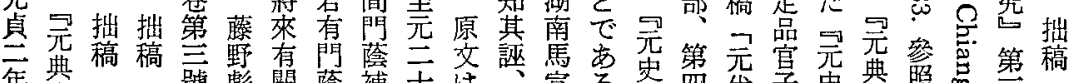

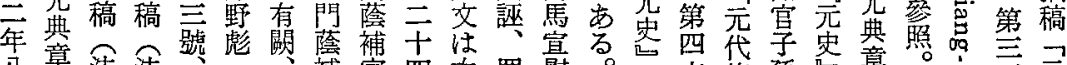
八意注注

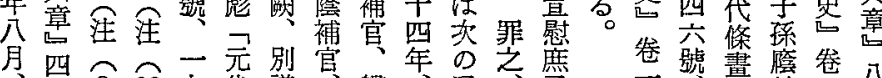

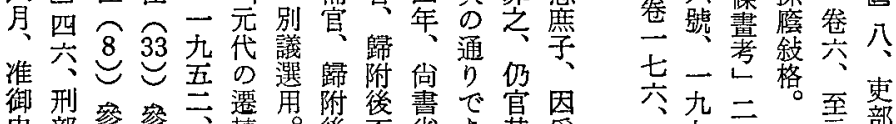

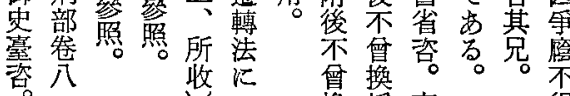

雼招

江怔

東番

道 異

宣 加

慰等

副

使の

李條

公流

燍 W

取

收沉

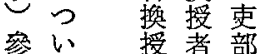

照七表旺

㑹食例菅

媛 资入

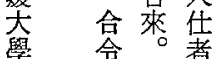

紀各擬多

要處自有

第候後中
得

䛟

靠

基

宾

宾

正

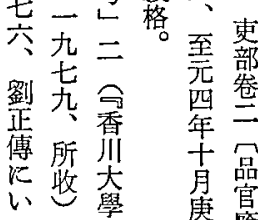

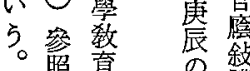

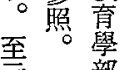

掌㜔

公報

年告

第
條體

飞然

5。紧宫它

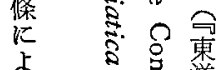

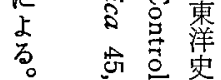

愍

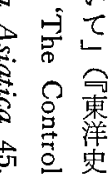

晋初

第江

官號保

H

芯苛

六稳

严所制

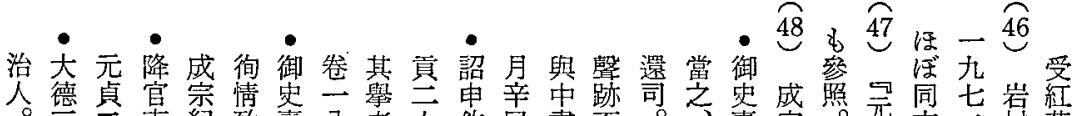

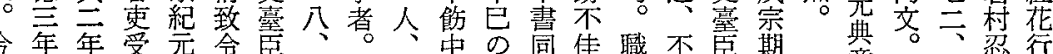

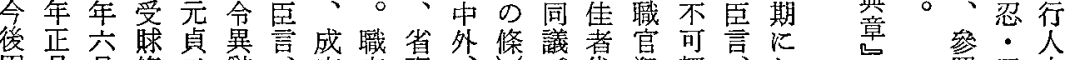

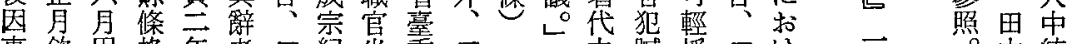

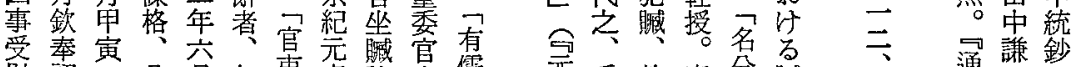

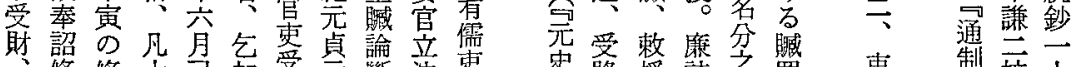

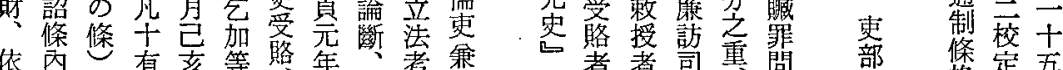

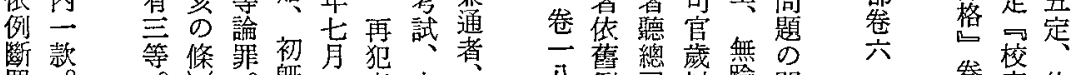

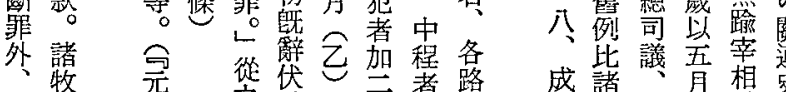

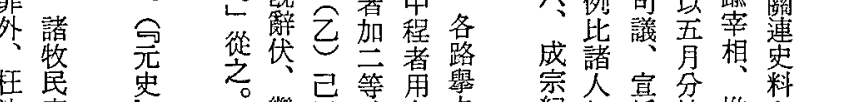

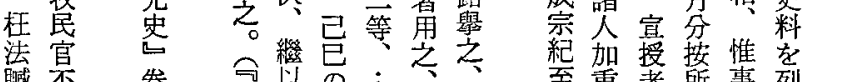

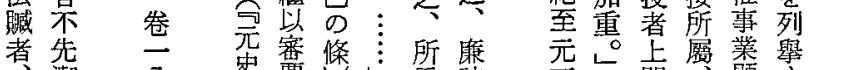

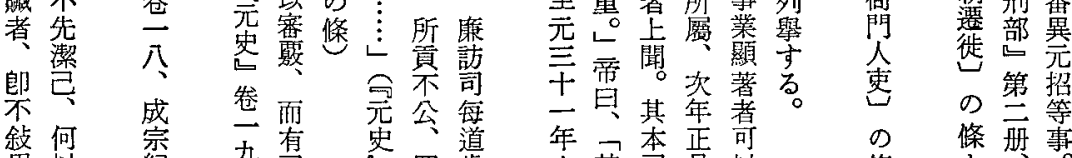

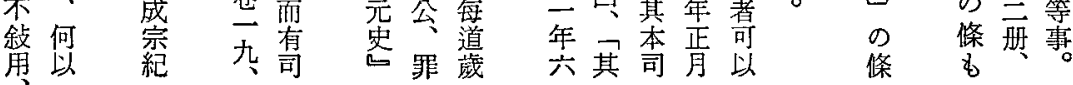


52 $\underset{7}{7} \widehat{51}$

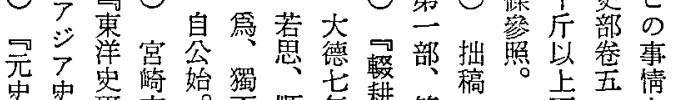

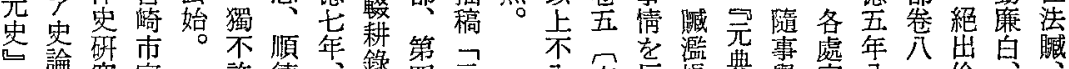

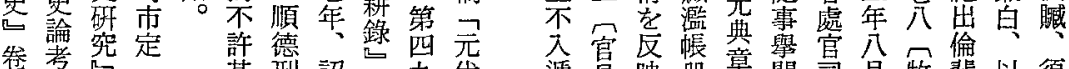

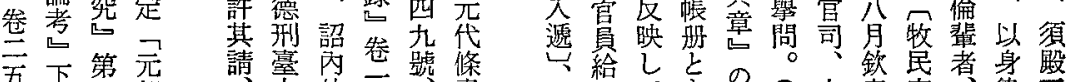

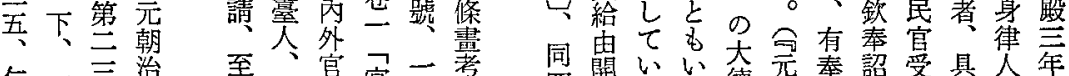

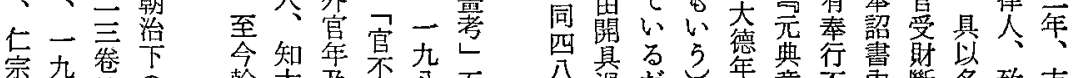
宗九第蒙 翰态及象瑟公五

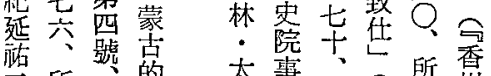

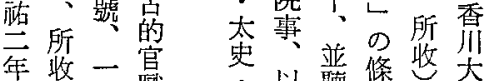

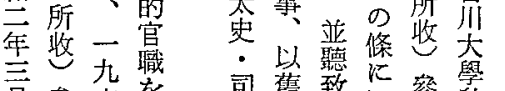

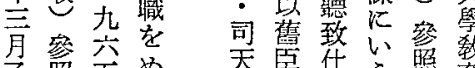

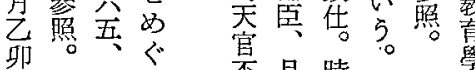

の所る 否時

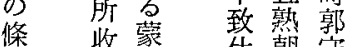

に赑蔡柋朝守

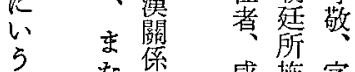

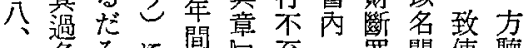
刑名万に間上至一罪聞使聽

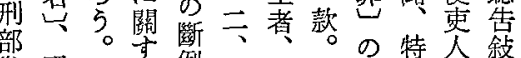
意同例方例聖仰 $\vdots$ 條加畏敍

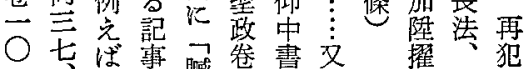

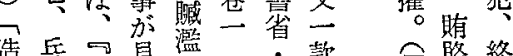

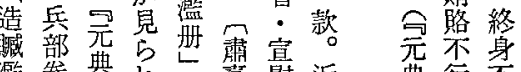

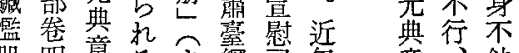
册四章るき綱司等音敍

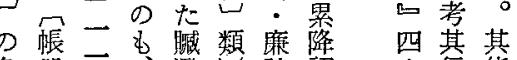

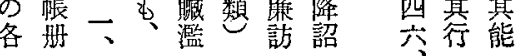

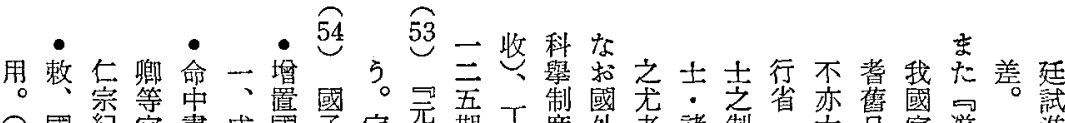

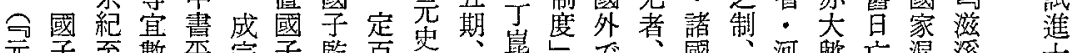

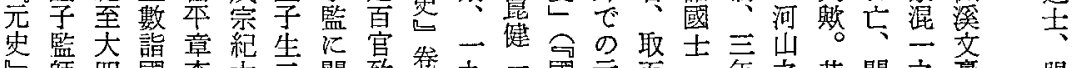

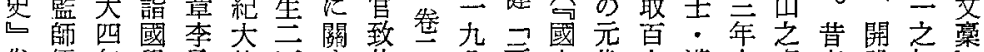
卷儒年學荋德百持西八元立代人漢大東者設初怘

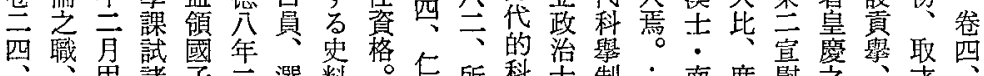
、羊諸登選 料

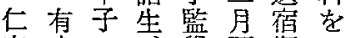
宗才の學丙衡可 紀德條勉宁戊大元

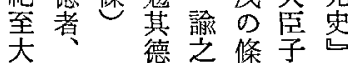

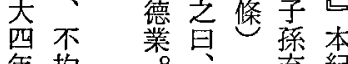

年拘 进口充紀

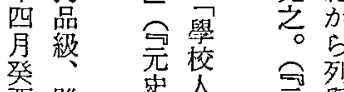

酉雖灰余坖舉

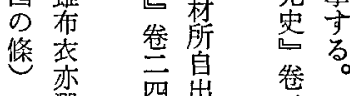
選

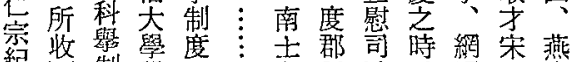
紀货學の：各縣及羅・南

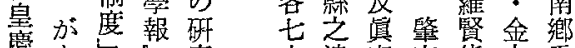

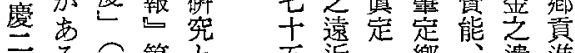

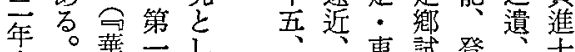
士。華學七て 合驗慗試登不題

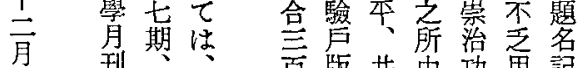

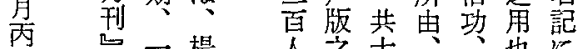
子 第克樹

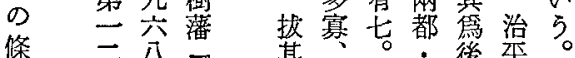
條三公元基凡其十管後 W 所代

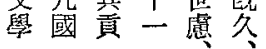

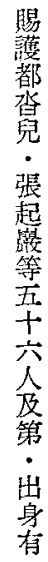



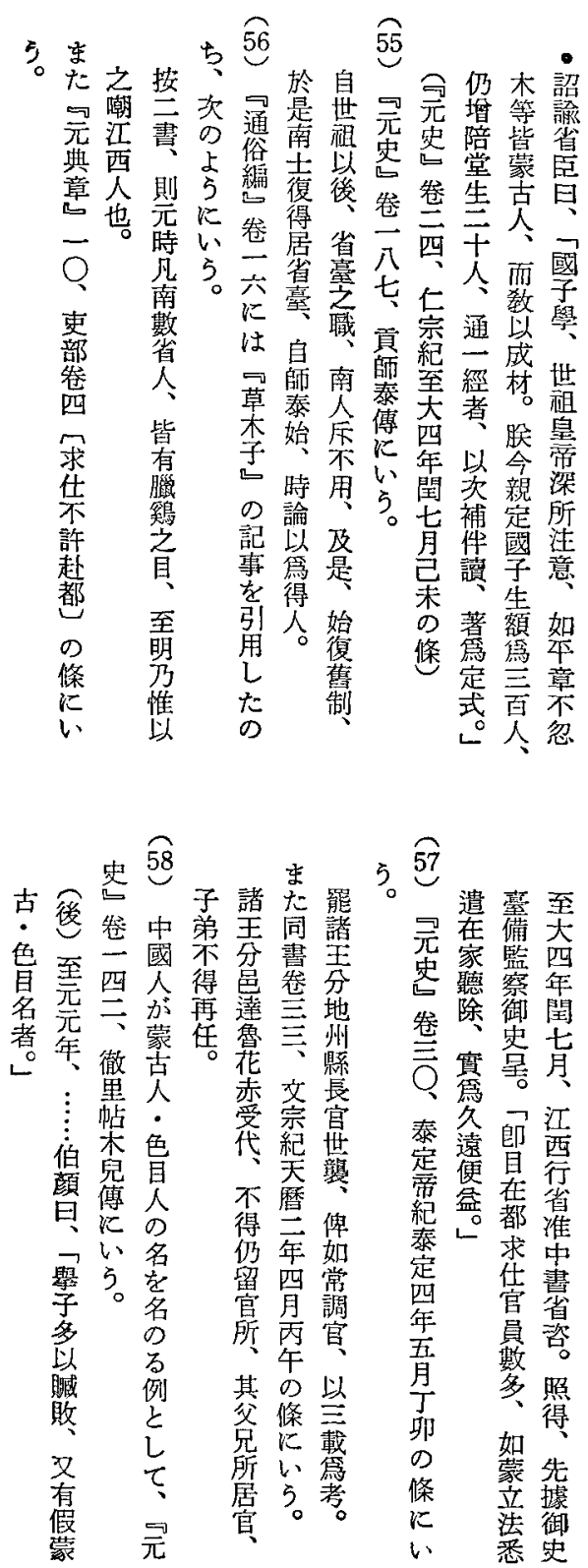
第 I 表 元代地方官職品表

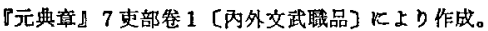

\begin{tabular}{|c|c|c|c|c|c|c|c|c|c|c|c|}
\hline 官品 & 宣得司 & 上路總管府 & 下路總管府 & 散府 & 上州 & 中州 & 下州 & 上縣 & 中縣 & 下縣 & 錄事司 \\
\hline $\begin{array}{l}\text { 從 } 2 \\
\text { 正 } 3 \\
\text { 從 } 3 \\
\text { 正 } 4 \\
\text { 從 } 4 \\
\text { 正 } 5 \\
\text { 從 } 5 \\
\text { 正 } 6 \\
\text { 從 } 6 \\
\text { 正 } 7\end{array}$ & $\begin{array}{l}\text { 宣想使 } \\
\text { 同知宣尌司事 } \\
\text { 宣奬副使 }\end{array}$ & 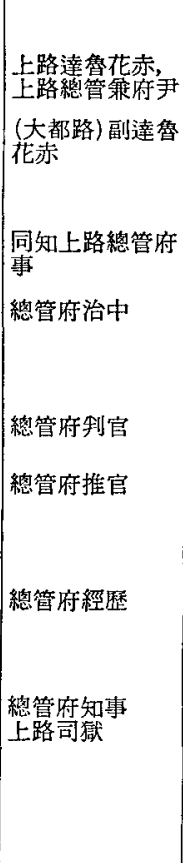 & 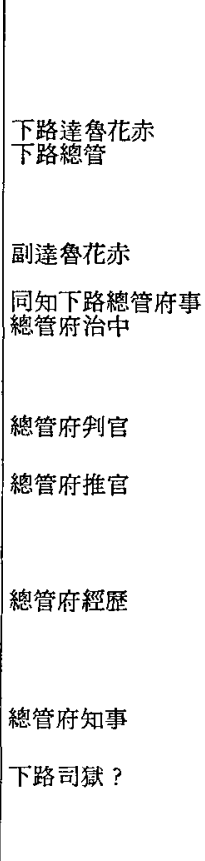 & $\begin{array}{l}\text { 達魯花赤 } \\
\text { 和府 } \\
\text { 同知散府事 } \\
\text { 散府制官 }\end{array}$ & $\begin{array}{l}\text { 澾魯花赤 } \\
\text { 同知上州事 } \\
\text { 上州制官 }\end{array}$ & $\begin{array}{l}\text { 達魯花赤 } \\
\text { 同知中州事 } \\
\text { 中州制官 }\end{array}$ & $\begin{array}{l}\text { 達魯花赤 } \\
\text { 知州 } \\
\text { 同知下州事 } \\
\text { 下州制官 }\end{array}$ & 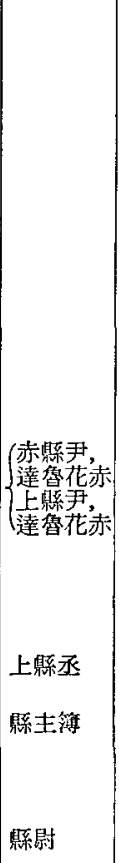 & 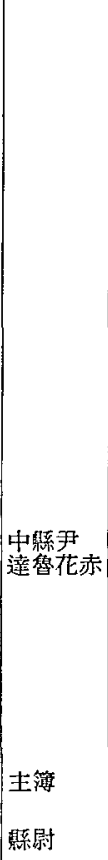 & $\begin{array}{l}\text { 下䣼尹 } \\
\text { 澾魯花赤 } \\
\\
\\
\text { 主簿 } \\
\text { 縣尉 }\end{array}$ & 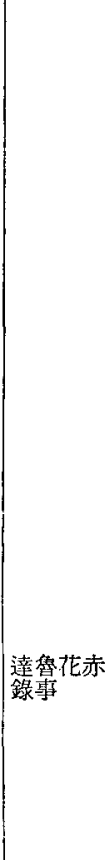 \\
\hline
\end{tabular}


第 II 表 宋末進士登第者の動向一筑

\begin{tabular}{|c|c|c|c|c|}
\hline 及第年 & 姓名 & 宋 代 官 職 & 元代官聝，あるいは動问 & 類型 \\
\hline 浮祐元年 & 哭覺 & 宣城令 & 警源渡糜書院山長 & $A^{\prime}$ \\
\hline \multirow[t]{4}{*}{ 淳祐 4 年 } & 謝昌元 & 沿海參議 & 禮部尚書 & A \\
\hline & 留夢炎 & 左丞相 & 禮部份書，翰林承旨 & A \\
\hline & 朱禩孫 & 京湖四川宣㭚使知江陵府 & 自殺。 & B \\
\hline & 李進 & 福建運管 & 罭居。 & B \\
\hline 注藏 7 年 & 兵富國 & 端陽僉制 ～～～～～～～～ & 不仕。 & B \\
\hline \multirow[t]{4}{*}{ 浔祐10年 } & 萧立之 & 知南城縣 ～辰州制官 & 蹛䎓。 & B \\
\hline & 陳杰 & 制置司虽官 & 元初猶存。 & C \\
\hline & $\begin{array}{l}\text { 曾淵子 } \\
\text { 本旬合 }\end{array}$ & 臨安府尹 $\rightarrow$ 廣西宣恐使䈴知雷州 & 元師入安南，率衆歸服。 & C \\
\hline & 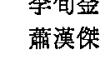 & 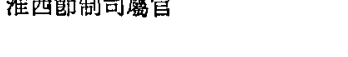 & $\begin{array}{l}\text { 不仕。 } \\
\text { 元初致仕。 }\end{array}$ & $\begin{array}{l}B \\
C\end{array}$ \\
\hline \multirow[t]{2}{*}{ 汻祐中 } & 葉汝舟 & 安吉州錄事案軍 & 提擧松江儒學 & A \\
\hline & $S$ 宋策孫 & 朝奉大夫 & 不仕。 & B \\
\hline \multirow[t]{2}{*}{ 寶祐元年 } & 陳大震 & 知全州－吏部侍郎（不就） & 司農卿, 庙東儒學提舉（皆鯜） & B \\
\hline & $\begin{array}{r}\text { 梅䍜登 } \\
\mathrm{S} \text { 陰幼遇 }\end{array}$ & 慶元府學教授 & $\begin{array}{l}\text { 不仕。 } \\
\text { 不仕。 }\end{array}$ & $\begin{array}{l}B \\
B\end{array}$ \\
\hline \multirow[t]{9}{*}{ 寶就 4 年 } & 蘇景瑞 & 太府寺丞 & 不出。 & $\mathrm{B}$ \\
\hline & 羅掎 & 臨安提轄権貨務 & 元初唒存。 & $\mathrm{C}$ \\
\hline & 蕭憡 & 主南安簿 一禮兵部架閣 & 家居。 & B \\
\hline & 婣漢傑 & & 溧陽路同知－建康路同知 & A \\
\hline & 穆演祖 & 衡陽愻尉 $\rightarrow$ 衡陽知縣 & 湖北僉憲 & A \\
\hline & 胡三省 & 沿江制機 & 家居。 & $\mathrm{B}$ \\
\hline & 趙與東 & 闌溪知縣 & 建德路燸學数授 & A \\
\hline & 舒岳詳 & & 寓居奉化。 & $\mathrm{B}$ \\
\hline & 吳釿 & 知石棣緜 & 悠游山水閣。 & B \\
\hline \multirow{4}{*}{$\begin{array}{l}\text { 寶祐中 } \\
\text { 開慶元年 }\end{array}$} & $\mathrm{S}$ 周燅 & 南晃知縣 & 暂不復仕。 & $\mathrm{B}$ \\
\hline & 蔣世傑 & 福州提辖榷貨務 & 紹與路學数授 & A \\
\hline & 交璧 & 知㤩州 & 惠州路總管 $\rightarrow$ 廣東宣慰司同知 $\rightarrow$ 宣慰寅西 & A \\
\hline & 陳宜係 & & 休孪縣尹＜wide>通州制官 & A \\
\hline \multirow[t]{12}{*}{ 景定 3 年 } & 鄧制 & 禮部侍郎權值學士 & 張弘箸請数其子, 後還郳。 & $\mathrm{C}$ \\
\hline & 王夢震 & 贑州零都縣簿 $\rightarrow$ 學新涂令 & 見國事日噔，毁不復仕。 & $\mathrm{B}$ \\
\hline & 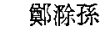 & 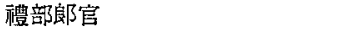 & 集豎直學士ー集賢學士 & A \\
\hline & 徐天祐 & 大州教授 & 杜門證畫。 & $\mathrm{B}$ \\
\hline & 方回 & 知建德府 & 建德路總管 & A \\
\hline & 曾浠顔 & 御史 & 湖南儒學提舉 & A \\
\hline & 汪復 & 太常簿 $\rightarrow$ 通制揚州 & 不仕。 & $\mathrm{B}$ \\
\hline & 王義山 & 永州司号 & 提舉江酉學事 & A \\
\hline & 方貢孫 & 監鎮江酒庫－領邢門縣事 & 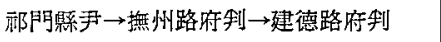 & A \\
\hline & 林璕 & 主管禮兵部架閣文字 & 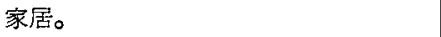 & $\mathrm{B}$ \\
\hline & 宗必經 & 通制通州 & 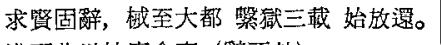 & B \\
\hline & 方逢振 & 國史實錄院檢閞文字 $\rightarrow$ 大府 & 淮西北道按察僉事（锌不赴） & B \\
\hline
\end{tabular}


元代江南の地方宫任用について

\begin{tabular}{|c|c|c|c|c|}
\hline 及第年 & 姓名 & 宋 代 官 職 & 元代官職，あるいは動向 & 類型 \\
\hline \multirow[t]{3}{*}{ 景定 3 年 } & $S$ 劉揚袓 & 江州教授 $\rightarrow$ 刑部員外郎 $\rightarrow$ 禮部郎中 & 不仕。 & B \\
\hline & S宗必礁 & 江西招討司計議官 & 不仕。 & B \\
\hline & S 幛渠 & & 不仕。 & B \\
\hline \multirow[t]{19}{*}{ 威淳元年 } & 熊孟莎 & 丽建㬍㞄司幹辦公事 & 家居。 & B \\
\hline & 棵天瑞 & 知金華係 & 䧮遁。 & B \\
\hline & 徐斗明 & & 慶元路學錄 & A \\
\hline & 胡鋪孫 & 知星子綮 & 攝衩門拲事 & A \\
\hline & 汪元龍 & 攝繁源縣事 & 徽州路治中 & A \\
\hline & 堄孟澡 & 挩州制司幹官 & 杭州路總管 $\rightarrow$ 桂陽路總管 & A \\
\hline & 堄必像 & 南康䑸丞 & 德居不出。 & B \\
\hline & 黃公紹 & & 不仕。 & B \\
\hline & 程龍 & 建德府推官 & 永嘉紫尹 $\rightarrow$ 松江府制 $\rightarrow$ 湘陰知州 & A \\
\hline & 畢㼛鳳 & 知石門縣 $\rightarrow$ 權知辰州 & 不復出。 & B \\
\hline & 朱炎 & 臨淮主簿 & 隐居不仕。 & B \\
\hline & 史蒙卿 & 景陵縣主簿 $\rightarrow$ 江陰教授 $\rightarrow$ 本江教授 & 不復仕。 & B \\
\hline & 何夢桂 & 監察御史 & 屡徵不起。 & B \\
\hline & 吳获 & 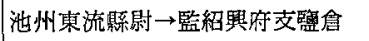 & 末末案歸。 & B \\
\hline & S 趋㗅司詔 & 土募魚海－紹興府司法參軍 & 䧮居。 & $\mathrm{B}$ \\
\hline & S 何䀤 & & 不仕。 & $\mathrm{B}$ \\
\hline & $\mathrm{S}$ 何桂發 & & 不仕。 & B \\
\hline & $S$ 黃丙炎 & 臨桂簿 $\rightarrow$ 宗正簿 & 不仕。 & B \\
\hline & *趋時播 & & 歸䧔。 & B \\
\hline \multirow[t]{22}{*}{ 咸淳 4 年 } & 羅惠瓀 & 湖北制置司幹辦公事 & 縜尉。 & A \\
\hline & 鄧德秀 & 澧州司戶寥軍 & & $\mathrm{C}$ \\
\hline & 慗立武 & 國子司美 & 家居。 & $\mathrm{B}$ \\
\hline & 汪一龍 & 句容縣尉 $\rightarrow$ 煦州教授 & 紫陽書院山長 & $\mathrm{A}^{\prime}$ \\
\hline & 陳龍 & 都昌縣主欂 & 定海縣海內寨巡㮝，清湘縣主簿 & A \\
\hline & 徐碩 & & 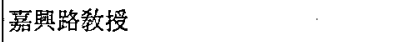 & A \\
\hline & 孫潼發 & 霍州軍事制官 & 家居不復仕。 & $\mathrm{B}$ \\
\hline & 胡以逰 & & 家居讀畫。 & B \\
\hline & 孔景行 & 慶元府學教授 $\rightarrow$ 禮兵部架閣 & 不復仕。 & B \\
\hline & 趙嗣助 & 惠州通制 & 不仕。 & B \\
\hline & 趙必范 & & & $\mathrm{C}$ \\
\hline & 暨子良 & 與安尉 $\rightarrow$ 淳安令 & 授寜僉不赴。 & B \\
\hline & 楊麟伯 & 揚州觀察推官 & 間居鄉里。 & B \\
\hline & 莫崙 & & 不仕。 & $\mathrm{B}$ \\
\hline & 梁棟 & 仁和㢦尉 & 不復任。 & $\mathrm{B}$ \\
\hline & 曹涇 & 昌化縣主導一權知昌化祘事 & 徽州紫陽書院山骎 & $A^{\prime}$ \\
\hline & 張卿厽 & 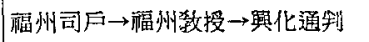 & 藍山畫院山長 & $A^{\prime}$ \\
\hline & 丁易東 & 太府寺簿萧楅密院稨修 & 不復仕。＜wide>＜wide>沅陽畫院山長 & $A^{\prime}$ \\
\hline & 姬交龍 & 京山簿 & 不復仕。 . & $\mathrm{B}$ \\
\hline & 姚雲 & 工刑部架閣 & 㩏建兩路儒學提舉 & A \\
\hline & 朱叔䃆 & 國子監壹庫宫 & 定海縣尹 $\rightarrow$ 浮梁州同知 $\rightarrow$ 慗州路治中 & A \\
\hline & S 革及 & 㽬州司戶窑軍 & 不仕。 & $\mathrm{B}$ \\
\hline
\end{tabular}




\begin{tabular}{|c|c|c|c|c|}
\hline 及第年 & 姓名 & 宋 代 宫 職 & 元代官職, あるいは動向 & 類型 \\
\hline 咸洦 4 年 & $S$ 胡次䊽 & 貫池尉 & 不仕。 & B \\
\hline \multirow[t]{18}{*}{ 威淳 7 年 } & 戴表元 & 建康府数授 & 信州路學数授 $\rightarrow$ 㢣州路學教授 & A \\
\hline & 魏新之 & 慶元府學教授 & 家居。 & $\mathrm{B}$ \\
\hline & 江䨳 & & 晦庵害院山長 $\rightarrow$ 闌溪主簿 & A \\
\hline & 黎廷端 & 㢣婜府司法參軍（未上） & 饒州路學教授 & A \\
\hline & 陳銭 & 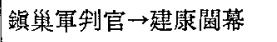 & 建康路學教授 & A \\
\hline & 覃元吉 & 鳥程縣尉 & 不復仕。 & B \\
\hline & 章昇 & 歴陽丰簿 & 鎭江路濂溪書院山曼 & $A^{\prime}$ \\
\hline & 趙與票 & 鄂州数授 & 翰林待制 $\rightarrow$ 翰林學士 & A \\
\hline & 趩孟何 & & 家居䄣畫。 & B \\
\hline & 趙良鈎 & 宗㦛敉授 $\rightarrow$ 廣德敎授 & 不仕。 & $\mathrm{B}$ \\
\hline & 趙孟路 & 埧州揚子跞主簿 & 以喘疾不出。 & $\mathrm{B}$ \\
\hline & 董師陚 & 平江府数官 & 浙西廉訪司敛事 & A \\
\hline & 丁衞 & 校豩郎 & 累石不起。 & B \\
\hline & 吳安朝 & 參議閩浙招捕司事 & 池州路制官一知賀州 & A \\
\hline & 杜文甫 & 國子博士 & 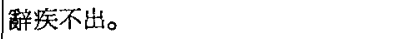 & $\mathrm{B}$ \\
\hline & 牟磼龍 & 光州定城㔠 & 不仕家貧。）教授溧陽 $\rightarrow$ 上元縣主簿 & A \\
\hline & 邵桂子 & 数授處州 & 不復仕。 & $\mathrm{B}$ \\
\hline & 何天聲 & 主管刑工部架閣文字 & 家居。 & $\mathrm{B}$ \\
\hline \multirow[t]{21}{*}{ 威淳10年 } & 蔣捷 & & 隱居, 㷴销莘蔦辟。 & $\mathrm{B}$ \\
\hline & 陳夢魁 & & 典敉嵊縣革 & A \\
\hline & 陳觀 & 臨安府新城縣尉 & 不仕。 & $\mathrm{B}$ \\
\hline & 劉應李 & 建陽縣主簿 & 化龍畫院 & $\mathrm{A}^{\prime}$ \\
\hline & 劉應俨 & 建昆軍僉制 & 艌去。 & $\mathrm{B}$ \\
\hline & 熊朗來 & & 福州路學教授 $\rightarrow$ 吉安路學教授 & A \\
\hline & 熊禾 & 寧武州司戶寥軍 & 家居請學。 & $\mathrm{B}$ \\
\hline & 郡濟民 & & 杭州路學教授 $\rightarrow$ 諸暨縣丞 $\rightarrow$ 義烏縣尹 & A \\
\hline & 修㯵 & 鎮㠌主簿 $\rightarrow$ 通州数授 & 家居。 & $\mathrm{B}$ \\
\hline & 胡之純 & & 行履如古獨行者。 & B \\
\hline & 胡幼黃 & 節度推官 & 避不出。 & B \\
\hline & 李消採 & & 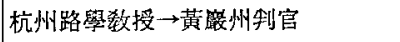 & A \\
\hline & 趙若謿 & & 同安縣尹 (不就) & $\mathrm{B}$ \\
\hline & 锄次陳 & & 陸居不仕。 & $\mathrm{B}$ \\
\hline & 崔君舉 & & 鳳山亩院山長 & $A^{\prime}$ \\
\hline & 王龍澤 & & 簽書昭慶軍節店制官 $\rightarrow$ 南臺御史 & A \\
\hline & 䦓量 & & 不受富䧊居。 & $\mathrm{B}$ \\
\hline & 袁易 & 學正 & 敉授於的 & B \\
\hline & 林桂發 & & 䥊江路學数授 $\rightarrow$ 淮東道儒學副提㦛 & A \\
\hline & 何希之 & 零陵数授 & 遁跡以終。 & $\mathrm{B}$ \\
\hline & S祀必 & 垍州路三司幹辦 & 不復仕。 & $\mathrm{B}$ \\
\hline \multirow[t]{4}{*}{ 威渖間 } & 王夢蓆 & & 崖山州學正 & A \\
\hline & 陳嘉言 & 建州司户 & 不復仕。 & $\mathrm{B}$ \\
\hline & 曹告春 & & 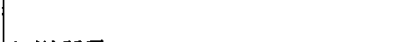 & $\mathrm{C}$ \\
\hline & 朱夢挂 & & 松滋妝夷 & A \\
\hline
\end{tabular}


元代江南の地方官任用について

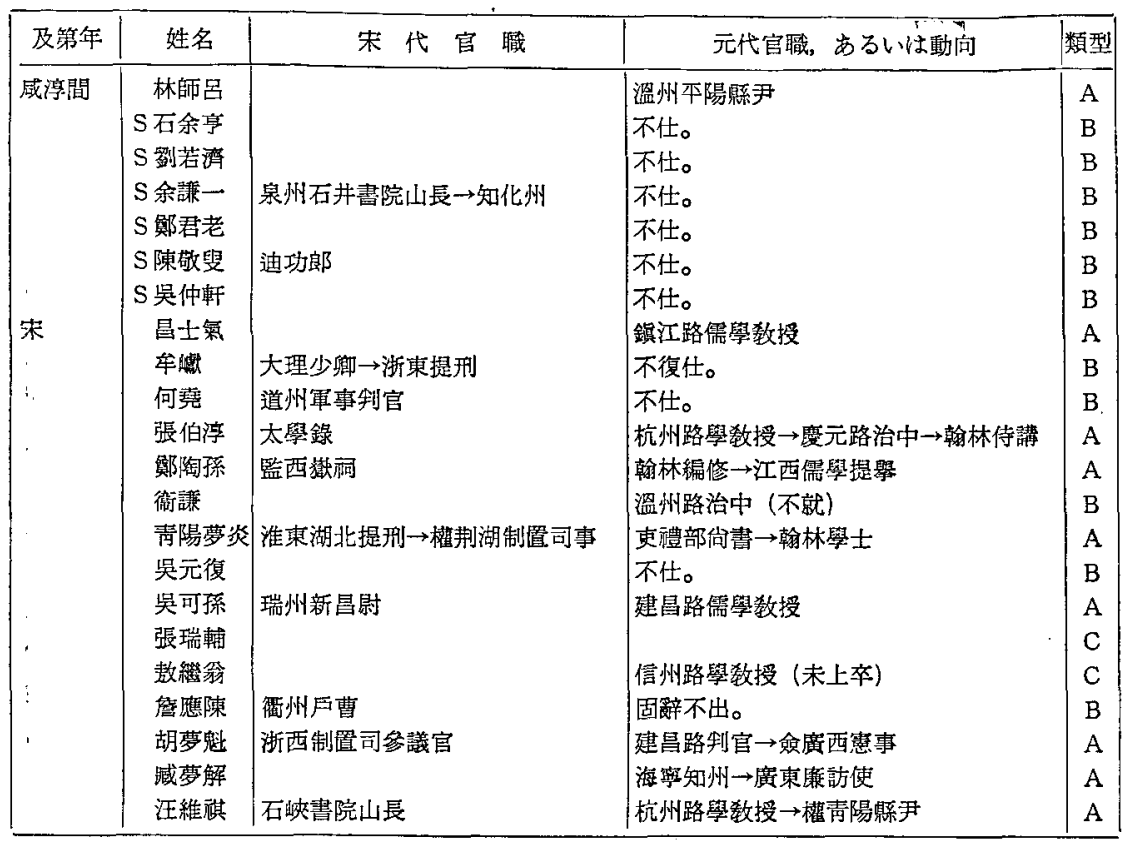

S『束李忠義錄』に上る。

*威汻九年は元年の譟りとみる。
A 元代に官途に就いたるの。
B 元代に入仕しなかったるの。
A' 書院關掭。
C 不明, 亦制斷しにくいる。

第四表 宋末進士登第者の動问類型

\begin{tabular}{|c|c|c|c|c|c|c|c|c|}
\hline & \multicolumn{2}{|c|}{ 就官 (內A') } & \multicolumn{2}{|c|}{ 不仕 } & \multicolumn{2}{|c|}{ 不明 } & \multicolumn{2}{|c|}{ 計 } \\
\hline 第 II 表全體 & $57(8)$ & $37.8 \%$ & 84 & $55.6 \%$ & 10 & $6.6 \%$ & 151 & $100.0 \%$ \\
\hline (Sを除く) & $57(8)$ & $43.2 \%$ & 65 & $49.2 \%$ & 10 & $7.6 \%$ & 132 & $100.0 \%$ \\
\hline 咸淳年間 & $34(7)$ & $36.9 \%$ & 55 & $59.8 \%$ & 3 & $3.3 \%$ & 92 & $100.0 \%$ \\
\hline (Sを除く) & $34(7)$ & $43.0 \%$ & 42 & $53.2 \%$ & 3 & $3.8 \%$ & 79 & $100.0 \%$ \\
\hline
\end{tabular}

單位 : 人 
第 $\mathrm{V}$ 表 延祐 2 年進士登第者

\begin{tabular}{|c|c|c|c|c|}
\hline 人名 & 本貫 & 初任官 & (舁品) & 异 \\
\hline 馬祖常 & 䔨古 & 翰林檻奉 & (從 7) & 監察御史, 翰林待制, 翰林直學士, 參議中甾省事, 御史中丞 \\
\hline 馬租考 & 陉古 & 陳州制官 & (正 8) & \\
\hline 偞轱篤 & 高昌 & & & 高郵縣平，泗州同知，西臺御史，工部台書，江西行省右丞 \\
\hline 丁哈八石 & 于䦓 & 固安州同知 & (正 7 ) & 監察御史, 山北僉憲 \\
\hline 王沂 & 埧定 & 翰林編修 & (正 8 ) & 國子博士，翰林待制，㡟部台畫 \\
\hline 張起笙 & 歴城 & 集賢修搇 & (從 6) & 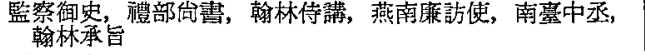 \\
\hline 梁宜 & 萑本 & 科州同知 & (正 7 ) & 國子助数，大名路制官，知順州，禮部向書 \\
\hline 李武毅 & 闐陽 & & & 監祭御史 \\
\hline 許有壬 & 湯陰 & 漟州同知 & (正 7 ) & 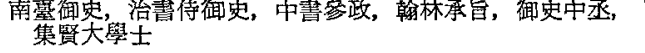 \\
\hline 韓渙 & 淮安 & & & 南臺御史，江浙省政，江渐省左丞，四川省左丞 \\
\hline 閻完 & 㷟西 & 杽山縣主簿 & (正 9 ) & 龍門縣尹 \\
\hline 張翔 & 河西 & & & 西臺御史, 浙東僉憲, 湖南僉憲 \\
\hline 王弁 & 長安 & & & 三原㲘平 \\
\hline 張士元 & 山陰 & 鄞騾丞 & (正 8$)$ & 貴池縣平，太平路經歷 \\
\hline 張宏道 & 山陰 & & & 太平路經歷 \\
\hline 趄䇠翁 & 聞喜 & 沉州制官 & (正 8 ） & 湖廣省照磨, 國子博士, 潮州路推官, 安陸府尹, 嘆州路總管 \\
\hline 王士元 & 臨汾 & & & 知吉州，國子司業，崇文少監 \\
\hline 交禮愷 & 嫁蜜 & 洋州同知 & 〈正 7$\rangle$ & \\
\hline 干文傳 & 吳縣 & 昌國州同知 & (正 7) & 長洲縣尹, 知吳江州, 集賢待制, 禮部台畫致仕 \\
\hline 曹敘中 & 龍游 & 奉化州同知 & (正 7) & 定海縣汽，富國路推官，石首縣尹 \\
\hline 黃洏 & 薐鳥 & 學海騾丞 & (正 8) & 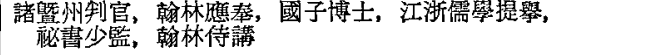 \\
\hline 楊载 & 錢塘 & 浮梁州同知 & (從 6) & 槃國路推官 \\
\hline 鄭南吉 & 莆田 & 龍㳂縣土簿 & (正 9) & \\
\hline 抙路 & 上高 & 新昌州判官 & (正 8) & \\
\hline 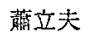 & 吉水 & 南豐州制官 & (正 8 ) & \\
\hline 許敏孫 & 建昌 & 南城縣丞 & (正 8$)$ & 贑州錄事，茶陵州制官 \\
\hline 楊景行 & 太和 & 會昌州制官 & (证 8$)$ & 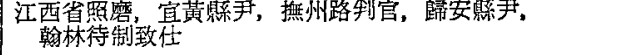 \\
\hline 纙算 & 盧陵 & 密都州制官 & (正 8) & 臨江錄事 \\
\hline 朱椪 & 烏琹 & 長洲縣丞 & (让 8) & \\
\hline 㞭朝瑞 & 茶陵 & & & 新军懸汽 \\
\hline 易光祖 & 巴陵 & & & 通堿縣尹 \\
\hline 乓堂 & 武昌 & & & 石門縣尹，平江州制宫 \\
\hline 馮稫可 & 醷陵 & 國子助数 & (正 8$)$ & 江西儒學提㦛 \\
\hline 楊察瑞 & 醴陵 & & & 翰林修撰，國子司業，翰林侍讀 \\
\hline 劉彭爰 & 衡山 & 平陽縣丞 & (证 8 ) & 岳州路行用庫使，淳安䝮肃， \\
\hline 歐陽玄 & 璆陽 & 平江州同知 & （正 7 ) & 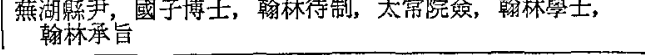 \\
\hline
\end{tabular}




\title{
The Appointment of the Local Officials in South \\ China during the Yuan 元 Period
}

\author{
by UEMATSU Tadashi
}

What was the change for Chinese officials in south China from the downfall of Song 宋 dynasty to the establishment of Yuan dynasty? Although we know the names of loyalists to former Song dynasty, due consideration should be also given to the appointment of the Chinese to the local offices under the conquest dynasty. Some Chinese literati 士人 including the successful candidates for the imperial examination 科舉 in Song period, remained to be the officials under the Mongolian rule. Some wealthy powerful locals 豪民 began to annex political, financial and social power in their native places. Therefore, many upstarts appeared in South China.

Worrying about the influence of the former dynasty, Yuan government took precautions against the local governers. However in many cases, the government could not obtain satisfactory results. Problems of the appointment had grown hard to solve easily. First was the redundancy of the local officials. In Shi-zu's 世祖 reign, Ahmad 阿合馬 wielded power in the government and appointed merchants and unqualified people as officials. Second was the wealthy powerful locals. They often engaged themselves in illegal activities especially concerning the landownership and payment of tax and corvée taking advantage of being appointed as officials. Third was the succession of the position by their descendants. To solve the problems stated above, Yuan government had to reexamine the appointment system.

In the early and middle Da-de 大德 era in Cheng-zong's 成宗 reign, high-ranking officials in South China such as Zhu Qing 朱清, Zhang Xuan 張瑄 and $\mathrm{Hu}$ Yi-sun 胡頤係 lost their position and were accused to death. In 1301 (Da-de 7), two Special Pacification Commissioners 奉 使宣無 were representatively dispatched to each six areas in China 
proper in order to watch local administration. They arrested a great number of officials amount to 18,473 for bribery, and cleared many people from the false charge. An act was decided to issue in the same year, though it is now not sure whether the act was actually put in force. Officials in the Provincial Secretariat 行省 were ordered to move to another province because they often did evil by means of the territorial relationship. It was just the same time when the following generation reached to the age to get position in the office.

In 1315 (Yan-you 延祐 2), the government conducted the first imperial examination, which was naturally welcomed by the Chinese Confucian scholars. It was carried out not only for meeting the earnest desire of Confucian scholars but for solving the problem of supply and demand of the local governers. The central government wanted to evade taking wealthy powerful locals, and assign the tallented governers including the Chinese, Mongolians and central Asians.

Finally the author emphasize the various efforts for the appointment system in Yuan period contributed to establish the bureaucracy in Ming 明 dynasty.

\section{A Reinterpretation of Art. 17 of the T'ang-lü (so-called 官當條)}

\section{by TSUKIGI Tadashi}

This article mainly argues about the interpretation of “最高者” in Art. 17 of the T'ang-lï; “先以高者當。謂職事等三官 (職事官, 散官, 衞官) 內, 最高者罍之。”

“最高者” is, in the popular view, interpreted as the position with the highest kuan-p'ing (官品) of the three positions.

This interpretation, however, can give no reasonable explanation for the following case; the case where a chih-shih-kuan (職事官) has a. kao-shen (告身) of the wei-kuan (衙官) with a kuan-p'ing which is higher in the grade than the kuan-p'ing to his going position the chih- 